UNIVERSIDADE DE SÃO PAULO

FACULDADE DE MEDICINA DE RIBEIRÃO PRETO

DEPARTAMENTO DE CLÍNICA MÉDICA

SEBASTIAN ANDRES VERNAL CARRANZA

Proteínas salivares de insetos hematófagos na patogênese do pênfigo foliáceo em amostragem brasileira

RIBEIRÃO PRETO

2019 
SEBASTIAN ANDRES VERNAL CARRANZA

Proteínas salivares de insetos hematófagos na patogênese do pênfigo foliáceo em amostragem brasileira

Tese apresentada à Faculdade de Medicina de Ribeirão Preto da Universidade de São Paulo para a obtenção do título de Doutor em Ciência Médicas; área de concentração: Clínica Médica; opção: Investigação Clínica. Subprojeto VIII que compõe o projeto temático "Relação dos fatores imunogenéticos e ambientais na etiopatogênese dos pênfigos em amostragem brasileira" FAPESP N. ${ }^{\circ}$ 2010/51729-2.

Orientadora: $\operatorname{Prof}^{a}$. Dr ${ }^{\mathrm{a}}$. Ana Maria Ferreira Roselino

\section{RIBEIRÃO PRETO}


Autorizo a reprodução e divulgação total ou parcial deste trabalho, por qualquer meio convencional ou eletrônico, para fins de estudo e pesquisa, desde que citada a fonte.

Ficha catalográfica

Vernal, Sebastian

Proteínas salivares de insetos hematófagos na patogênese do pênfigo foliáceo em amostragem brasileira. Sebastian Vernal; Orientadora Prof ${ }^{\mathrm{a}}$. Dr ${ }^{\mathrm{a}}$. Ana Maria Ferreira Roselino. Ribeirão Preto, 2019. $159 f$

Tese (Doutorado Direto) - Faculdade de Medicina de Ribeirão Preto da Universidade de São Paulo. Programa de Pós-Graduação em Clínica Médica. Área de concentração: Investigação Clínica.

1. Pênfigo foliáceo. 2. Fogo selvagem 3. Desmogleína 1. 4. Inseto 5. Diptera 6. Psychodidae 7. Simuliidae 
VERNAL, S. Proteínas salivares de insetos hematófagos na patogênese do pênfigo foliáceo em amostragem brasileira

Tese apresentada à Faculdade de Medicina de Ribeirão Preto da Universidade de São Paulo para a obtenção do título de Doutor em Ciências Médicas do Programa de Clínica Médica. Área de concentração: Investigação Clínica.

Aprovada em:

\section{Banca examinadora}

Prof $^{\mathrm{a}}$. Dr ${ }^{\mathrm{a}}$. Ana Maria Ferreira Roselino Instituição: FMRP, USP

Julgamento:

Assinatura:

Prof. Dr.

Instituição:

Julgamento:

Assinatura:

Prof. Dr.

Instituição:

Julgamento:

Assinatura:

Prof. Dr.

Instituição:

Julgamento:

Assinatura:

Prof. Dr.

Instituição:

Julgamento:

Assinatura: 
Dedico este trabalho à meu amor, minha esposa; à meu maior presente da vida, minha filha; à meu suporte nesse mundo, meus pais e irmãos; e especialmente aos que me permitiram estar onde estou, meus avós. 
À minha esposa, Thaís, exemplo de amor sem medidas nem distâncias; minha companheira de travessias no que resta do meu andar, junto andarei a teu lado até que nossos passos acabem, até que dê o último suspiro por você nessa terra e nosso amor perdure em nossos frutos por toda a eternidade.

À minha filha, Isabella, sangue de meu sangue, a expressão de meu querer e o produto de uma história que saberá contar e lembrar com carinho do homem que te abraçou por primeira vez, com os anos, com as vidas que seguirão, sem esquecer que seguirás sendo alma de minha alma.

A mis padres, Genoveva y Raúl, que me concedieron mi espíritu viajante, a buscar puertos para zarpar y nuevos lares para crear, sin perder en el arte nómade el carisma de mi tierra y las enseñanzas que recibí antes de emprender el vuelo hacia polos opuestos, pero jamás olvidando el nido donde fui creado y criado.

A mis hermanos, Felipe y Diego, orgullo de sangre vieja que llama los instintos paternales ante las otoños que nos separan, años que separan igual distancias, pero que recuerdan día a día la importancia de saber que están ahí, que me cuidarán y que los cuidaré como si fuesen míos.

A minha orientadora, primeiro por confiar em alguém sem nome, abrir uma porta as cegas e dar uma oportunidade para demonstrar o que hoje finalizamos juntos. Minha mãe acadêmica, que me viu amadurecer, que me ensinou e corrigiu, e que me deu as ferramentas para hoje fazer o que mais gosto da melhor maneira possível. Levarei por sempre o cofre de lembranças e a mochila cheia de aprendizados. Como seu filho doutoral, levarei sempre seu nome na minhas costas e espero sempre dar um orgulho para a senhora.

Ao Dr. Mateus Pepinelli, por todas nossas conversas enquanto nos aventurávamos no meio de matos, lagoas e rios (sendo constantemente picados). Sem você esse trabalho não teria sido possivel. Agradecerei sempre sua disposição, sua ajuda e todo o aprendizado.

Ao Dr ${ }^{a}$. Mara Pinto, Dr ${ }^{a}$. Thaís Goulart e Dr. Wanderson Oliveira, pela confiança ao bater as portas e principalmente pela sempre boa disposição. Simplesmente sua ajuda foi indispensável para levar a cabo esse trabalho!

Ao Dr. Anderson Sá-Nunes, pelo acolhimento no seu laboratório e pela constante disposição em colaborar no desenvolvimento dessa tese. Sua participação foi um pilar fundamental!

Ao Dr. Álvaro Casanova, pela fornecimento de informações absolutamente primordiais na confecção desse estudo. 
Ao Dr. José Ribeiro e Dr. Fabiano Oliveira, pela colaboração, o aprendizado e a valiosa ajuda para hoje ter uma importante base de dados depositados que serão peça fundamental no entendimento dos flebotomíneos.

À Profa. Dra. Karla Arruda pelo acolhimento no seu laboratório e a disposição em colaborar.

Ao Dr. Takashi Hashimoto, Dr. Norito Ishii e os técnicos do laboratório de Dermatologia da Kurume University, pela recepção, as risadas no karaokê, as diversas comidas, os tours e obviamente o imenso aprendizado para o correto desenvolvimento dessa tese.

À Natália de Paula, que simplesmente essa tese não existiria sem sua ajuda. Melhor amiga, melhor parceira de aventuras (e a melhor "isca”), não tenho palavras para agradecer toda sua ajuda ao longo desses anos. Matos, rios, lagoas e campos...sem dúvidas levarei sempre você no meu coração!

À Aline Turatti, pela paciência (muita paciência mesmo), por ser meu apoio no laboratório para não "sumir" e pela companhia dia a dia durante o desenvolvimento desse trabalho. Seus conselhos foram fundamentais para hoje chegar hoje até o fim. Obrigado mesmo!

Ao Prof. Dr. Ciro Gomes, pelo grande aprendizado, pelas oportunidades e pela sua amizade. Um homem digno de imitar, que admiro e que orgulho. Sem dúvidas um exemplo a seguir. A definição da palavra "diferenciado”. Agradecido sempre!

Ao Prof. Dr. Marco Andrey, pelas oportunidades e o grande aprendizado. Admiração infinita por sua vocação de serviço. Jamais esquecerei sua preocupação e cuidados quando fiquei doente.

À Tamiris e a Marcela, pela amizade, suporte e ajuda. Vocês fizeram meu dia a dia mais fácil e ameno no laboratório. Super obrigado mesmo meninas!

Ao Leonardo, Aline Lobo, Daniela e Aline Rafaela pelo acolhimento e suporte nos meus primeiros passos. Agradeço as orientações, dicas e conselhos. Sentirei saudades do "bandejão" $e$ “sertãozinho” (...só que não).

À Sandra e Flávia por toda a ajuda e disposição sempre com um grande sorriso :)

À Ana Cristina (secretária da Divisão de Dermatologia) por todo auxilio.

Ao Emerson (secretário da pós-graduação em Clínica Médica) por toda paciência e valiosa ajuda em todos os processos burocráticos.

A todos os médicos assistentes do ambulatório de Dermatologia pela receptividade e auxílio.

À CAPES pela bolsa concebida e a FAPESP pelo suporte económico ao longo desse Doutorado.

E a todos que contribuíram direta ou indiretamente na minha formação. 
"Los días más felices son aquellos que nos hacen más sabios" 


\section{RESUMO}

VERNAL, S. Proteínas salivares de insetos hematófagos na patogênese do pênfigo foliáceo em amostragem brasileira, 2019, 159f. Tese (Doutorado) - Faculdade de Medicina de Ribeirão Preto, Universidade de São Paulo, 2019.

Introdução. Os pênfigos representam um grupo de dermatoses bolhosas autoimunes caracterizados pela produção de autoanticorpos contra as desmogleínas (Dsg). O pênfigo foliáceo (PF) decorre da produção de autoanticorpos contra Dsg1. No Brasil, o PF é descrito em focos geográficos definidos: áreas rurais próximas de bacias hidrográficas. Considerando essa distribuição, tem-se aventado a hipótese de que fatores ambientais, aliados à associação de alelos $H L A$, tenham papel na sua endemicidade, interrogando-se a participação de insetos hematófagos na etiopatogênese do PF. Objetivos. Verificar a participação das proteínas salivares de insetos hematófagos na etiopatogênese do PF em amostragem da região nordeste do estado de São Paulo (NESP), Brasil. Como objetivos específicos: (i) documentar a relação epidemiológica (fator de risco/doença) das principais espécies de insetos antropofílicos com a distribuição geográfica dos casos de PF no NESP; (ii) avaliar a resposta imune humoral IgG em pacientes com PF e controles contra extratos proteicos salivares (EPS) de Aedes aegypti, Nyssomyia neivai e Simulium nigrimanum, e contra as proteínas salivares maxadilan (expressa em Lutzomyia longipalpis e N. neivai) e LJM11 (expressa em Lu. longipalpis), e correlacionar essas respostas com os títulos anti-Dsg1; (iii) quantificar o IgE total e anti-IgE contra ESP dos insetos citados, em pacientes com PF e controles, e (iv) descrever o sialoma de N. neivai. Métodos. Os dados dos casos de PF e das principais espécies hematófagas do NESP foram registrados em mapas de distribuição espacial (ArcGIS v10.2). Para a detecção de anticorpos séricos (IgG e IgE) contra os EPS realizou-se ELISA in-house seguida de immunoblotting (IB). A dosagem de IgE total foi realizada pelo kit ImmunoCAP ${ }^{\mathrm{TM}}$ Total IgE segundo as instruções da fabricante. Para a detecção de anticorpos séricos ( $\operatorname{IgG}$ ) contra maxadilan e LJM11 também usou-se ELISA in-house. A quantificação de anticorpos anti-Dsg1 foi feita por ELISA comercial (MBL, Japão). A descrição do sialoma foi realizada com tecnologia Illumina RNA seq. A análise estatística para cada objetivo foi feita com testes não paramétricos. Resultados. Houve confirmação entre a distribuição geográfica dos insetos hematófagos S. nigrimanum e Nyssomyia neivai com os casos de PF registrados no NESP, confirmando elo epidemiológico. Pacientes com PF apresentaram maiores títulos de anticorpos IgG contra EPS de $S$. nigrimanum $(P<0.001)$ e de $N$. neivai $(P<0.050)$, comparados aos controles, porém sem diferença em relação ao EPS de $A$. aegypti $(P=0.469)$. Os pacientes com PF apresentaram maiores níveis de IgE total em comparação aos controles $(P<0.001)$. Títulos de anticorpos contra EPS de $S$. nigrimanum e $N$. neivai correlacionaram-se com os títulos de anti-Dsg1 no grupo $\mathrm{PF}(\mathrm{r}=0.384, P=0.039$ e $\mathrm{r}=0.416$, $P=0.022$, respectivamente). Títulos de anticorpos IgE contra EPS de A. aegypti, S. nigrimanum e $N$. neivai correlacionaram-se com títulos de IgE total no grupo PF; e maiores títulos IgE contra EPS de $N$. neivai e A. aegypti foram observados no grupo PF, em comparação aos controles $(P<0.001$ ambos). Anticorpo IgE contra EPS de $N$. neivai evidenciaram uma correlação positiva com os títulos de anti-Dsg1 no grupo PF $(P=0.077)$. Frações proteicas de EPS foram reconhecidas pelos pacientes com $\mathrm{PF}$ e controles no IB, sendo que PF reconheceram principalmente frações proteicas 
menores de $60 \mathrm{kDa}$ do EPS S. nigrimanum e entre 5-10kDa do EPS de N. neivai. Ainda, maiores títulos de IgG anti-maxadilan, mas não anti-LJM11, foram identificados no grupo PF comparado aos controles $(P<0.001)$. Títulos de IgG anti-maxadilan correlacionaram-se com títulos de IgG antiESP de N. neivai, assim como com anti-Dsg1 no grupo PF. Conclusão. Um link epidemiológico entre a distribuição dos casos de $\mathrm{PF}$ e das espécies $S$. nigrimanum e $N$. neivai foi confirmado no NESP. A exposição à picada desses insetos foi confirmada pela produção de anticorpos da classe IgG e IgE, com reconhecimento de várias frações proteicas do EPS, sugerindo a participação de diversos peptídeos salivares de insetos hematófagos na etiopatogênese do PF. Ainda, a correlação dos anticorpos anti-ESP e anti-maxadilan com anti-Dsg1 mostra possível mimetismo molecular, e participação das proteínas salivares na patogênese do PF no NESP.

Palavras chave: Pênfigo foliáceo; Desmogleína; Diptera; Psychodidae; Simuliidae; Culicidae 


\section{ABSTRACT}

VERNAL, S. Salivary proteins of hematophagous insects in the pathogenesis of pemphigus foliaceus in a Brazilian sample, 2019, 159p. Doctoral Thesis - Ribeirão Preto Medical School, University of São Paulo, 2019

Introduction. Pemphigus encompasses a group of autoimmune bullous dermatoses characterized by the production of autoantibodies against desmogleins (Dsg). Pemphigus foliaceus (PF) results from the production of autoantibodies against Dsg1. In Brazil, PF is described in well-defined geographic foci: rural areas near watersheds. Considering this distribution, it has been hypothesized that environmental factors, allied to the association of $H L A$ alleles, play a role in PF endemicity, questioning the participation of hematophagous insects in the PF pathogenesis. Main objective. To verify the participation of salivary proteins of hematophagous insects in the PF etiopathogenesis in a sample from northeastern São Paulo state (NSPS), Brazil. As specific objectives: (i) document the epidemiological relationship (risk factor/disease) of the main species of anthropophilic insects with the geographic distribution of PF cases in NSPS; (ii) to evaluate the humoral IgG immune response in patients with PF and controls against Aedes aegypti, Nyssomyia neivai and Simulium nigrimanum salivary gland extracts (SGE), and against maxadilan salivary proteins (expressed in Lutzomyia longipalpis and $N$. neivai) and LJM11 (expressed in Lu. longipalpis), and correlate these responses with anti-Dsg1 titers; (iii) quantify the total IgE and anti-IgE against SGE of the cited insects, in patients with PF and controls, and (iv) describe N. neivai sialoma. Methods. Data from the PF cases and the main hematophagous species of NSPS were recorded in spatial distribution maps (ArcGIS v10.2). For the detection of serum antibodies (IgG and IgE) against SGE, in-house ELISA was performed followed by immunoblotting (IB). Total IgE dosing was performed by the ImmunoCAP ${ }^{\mathrm{TM}}$ Total IgE kit according to the manufacturer's instructions. Serum antibodies (IgG) against maxadilan and LJM11 were also used in-house ELISA. Quantification of anti-Dsg1 autoantibodies was done by commercial ELISA (MBL, Japan). The description of the sialoma was performed using Illumina RNAseq. Statistical analysis for each objective was performed with nonparametric tests. Results. There was confirmation between the geographic distribution of the hematophagous insects $S$. nigrimanum and Nyssomyia neivai with the cases of PF registered in NSPS, confirming the epidemiological link. Patients with PF had higher IgG antibodies titers against $S$. nigrimanum $(P<0.001)$ and $N$. neivai $(P<0.050)$ SGE compared to controls, but no difference from $A$. aegypti SGE $(P=0.469)$. Patients with $P F$ had higher total IgE levels compared to controls $(P<0.001)$. Antibody titers against $S$. nigrimanum and $N$. neivai correlated with anti-Dsg1 titers in the PF group ( $\mathrm{r}=0.384, P=0.039$; and $\mathrm{r}=0.416, P=0.022$, respectively). IgE antibodies titers against SGE from $A$. aegypti, S. nigrimanum and $N$. neivai correlated with total IgE titers in the PF group; and higher SGE IgE titers from $N$. neivai and $A$. aegypti were observed in the PF group compared to controls $(P<0.001$ both). IgE antibody against $N$. neivai SGE showed a positive correlation with anti-Dsg1 titers in the PF group $(P=0.077)$. SGE protein fractions were recognized by patients with $\mathrm{PF}$ and controls in IB assay, and PF mainly recognized protein fractions smaller than $60 \mathrm{kDa}$ from SGE from $S$. nigrimanum and between $5-10 \mathrm{kDa}$ from $N$. neivai SGE. Further, higher anti-maxadilan but not anti-LJM11 IgG titers were identified in the PF group compared to controls $(P<0.001)$. Anti-maxadilan IgG titers correlated with IgG anti-SGE from $N$. neivai titers as well as anti-Dsg1 in PF group. Conclusion. An epidemiological link between the distribution of PF cases and S. nigrimanum and N. neivai species was confirmed in NSPS. Exposure to the bite of these insects was confirmed by the production of IgG and IgE class antibodies, with recognition of several SGE protein fractions, suggesting the participation of several salivary peptides of hematophagous insects in PF etiopathogenesis. Moreover, the correlation of anti-SGE and anti- 
maxadilan antibodies with anti-Dsg1 shows possible molecular mimicry, and participation of salivary proteins in the pathogenesis of PF in NSPS.

Keywords: Pemphigus foliaceus; Desmogleina; Diptera; Psychodidae; Simuliidae; Culicidae 


\section{LISTA DE FIGURAS}

Figura 1. Estrutura microscópica e representação esquemática do Desmossomo. Microscopia eletrônica evidenciando o Desmossomo seguido de representação esquemática dos diferentes componentes envolvidos na adesão celular. Dsg: Desmogleínas; Dsc: Desmocolinas; KIF: filamentos intermédios de queratina.

Fonte: KOTTKE et al., 2006

Figura 2. Focos de Pênfigo Foliáceo endêmico no Estado de São Paulo. Representação esquemática do estado de São Paulo identificando os casos de pênfigo foliáceo endêmico (pontos pretos). Observa-se a distribuição geográfica (próximos de bacias hidrográficas) e em conglomerados principalmente na cidade de Franca, Ribeirão Preto e Araraquara.

Fonte: DIAZ et al., 1989

Figura 3. Maduração e clivagem das Desmogleínas. De esquerda à direita: a expressão do pro-peptídeo (precursor da Desmogleína 1 com os domínios extracelulares EC1 EC5) seguido da maturação e pós clivagem no desmossomo.

Fonte: YOKOUCHI et al., 2009

Figura 4 - Etiopatogênese do pênfigo foliáceo endêmico. Representação esquemática do queratinócito com destaque na Desmogleína 1 incluindo os domínios extracelulares EC1 - EC5. Anticorpos do subtipo $\operatorname{IgG}_{1}$ (nos patogênicos - representados em laranja) contra o domínio EC5. Observa-se a mudança no perfil sorológico devido a fatores genéticos (alelos HLA de susceptibilidade) e ambiente, levando a produção de autoanticorpos do tipo $\mathrm{IgG}_{4}$ (patogênicos - representados em vermelho) contra o domínio EC1.

Fonte: HANS-FILHO et al., 2018

Figura 5. Mecanismo de acantólise nos pênfigos. Acima à direita observa-se a estrutura normal do desmossomo. Em seguida mostra acima à direita e embaixo os três mecanismos que explicariam o proceso de acantólise, incluindo o bloqueio mecânico (steric hindrance), a depleção de Desmogleínas devido a fenômenos de agrupação e internalização, e a ativação de vías de sinalização que contribuiriam com o enfraqueciemento dos enlaces.

Fonte: KASPERKIEWICZ et al., 2017

Figura 6. Papel dos anticorpos $\operatorname{IgG}_{4}$ na alergia e hipersensibilidade. Representação esquemática dos mecanismos pelos quais os anticorpos IgG4 participariam na resposta alérgica e de hipersensibilidade.

Fonte: KONECZNY et al., 2018

Figura 7. Evolução da resposta alérgica durante exposição crônica. Em fase aguda, o estímulo alérgico leva a uma resposta $\mathrm{Th}_{2}$ com uma produção de anticorpos maioritariamente do tipo IgE (acima). A exposição crônica dos alérgenos estimularia uma modulação por IL-10 visando uma redução dos efeitos imunológicos associados à hipersensibilidade associado a uma troca de classe para anticorpos do tipo $\operatorname{IgG}_{4}$.

Fonte: TRAMPERT et al., 2018 
Figura 8. Georreferenciamento da distribuição do Simulium nigrimanum no estado de São Paulo, Brasil. Locais de coleta positiva (pontos pretos) do borrachudo Simulium nigrimanum no estado de São Paulo, Sudeste Brasileiro.

Figura 9. Distribuição de Nyssomyia neivai em relação aos casos reportados de Leishmaniose Tegumentar Americana no Estado de São Paulo. Representação esquemática dos municípios do estado de São Paulo. Em tonalidades de amarelo até vermelho (baixa até alta respectivamente) mostram a incidência de Leishmaniose Tegumentar Americana. Municípios riscados revelam a presença de Nyssomyia neivai.

Fonte: SHIMABUKURO et al., 2010

Figura 10. Distribuição de Lutzomyia longipalpis no Estado de São Paulo. Representação esquemática dos municípios do estado de São Paulo. Em tonalidades de cinza mostra-se a pesquisa entomológica positiva, negativa ou não pesquisa de Lutzomyia longipalpis.

Fonte: CAMARGO-NEVES et al, 2003

Figura 11. Hipótese sobre a reatividade cruzada entre antígenos ambientais e a etiopatogênese do pênfigo foliáceo endêmico. A exposição ao estímulo ambiental (nesse caso a proteína salivar LJM11) levaria inicialmente a uma resposta por hipersensibilidade à produção de anticorpo $\operatorname{IgE}$ anti-LJM11 os quais levariam um reação cruzada por mimetismo antigênico à produção de anticorpos IgE anti-Desmogleína 1. A exposição crônica levaria a uma estimulação de IL-10 e consequentemente a uma troca do perfil de anticorpos para $\operatorname{IgG}_{4}$ (patogênicos) contra Desmogleína 1 .

Fonte: QIAN et al., 2016 


\section{LISTA DE ABREVIATURAS}

A. aegypti Aedes aegypti

Dsc Desmocolina

Dsg Desmogleína

FAPESP Fundação de Amparo à Pesquisa do Estado de São Paulo

HLA Human leukocyte antigen

IgE Imunoglobulina classe $\mathrm{E}$

IgG Imunoglobulina classe $\mathrm{G}$

$\mathrm{IgG}_{1} \quad$ Imunoglobulina classe $\mathrm{G}$ subtipo 1

$\mathrm{IgG}_{4} \quad$ Imunoglobulina classe $\mathrm{G}$ subtipo 4

IL Interleucina

Lu. longipalpis $\quad$ Lutzomyia longipalpis

L. (L.) Leishmania Complexo Leishmania

LTA Leishmaniose Tegumentar Americana

LV Leishmaniose Visceral

L. (V.) Leishmania Complexo Viannia

MHC Major Histocompatibility Complex

N. neivai Nyssomyia neivai

PB Penfigóide bolhoso

PF Pênfigo foliáceo

PV Pênfigo Vulgar

S. nigrimanum Simulium nigrimanum

S. vittatum Simulium vittatum

$\mathrm{Th}_{2} \quad$ Linfócito T helper 2 
SUMÁRIO

1. INTRODUÇÃO -

2. REVISÃO BIBLIOGRÁFICA -

3. OBJETIVOS - 47

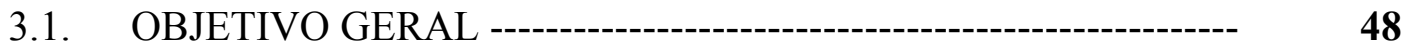

3.2. OBJETIVOS ESPECÍFICOS --- 48

4. RESULTADOS -- 49

4.1. ARTIGOS PUBLICADOS ---

4.2. ARTIGOS SUBMETIDOS - -

5. CONCLUSÃO -

6. REFERÊNCIA BIBLIOGRÁFICAS -------- 146

7. ANEXOS -- 
Introdução 


\section{INTRODUÇÃO}

Os pênfigos se referem a um grupo de dermatoses bolhosas autoimunes, caracterizados pelo acometimento da pele e/ou das mucosas devido à produção de autoanticorpos contra proteínas desmossomais. A ligação dos autoanticorpos IgG no complexo desmosomal conduz à perda da adesão dos queratinócitos, processo conhecido como acantólise, e consequentemente à formação de bolhas intraepiteliais (HAMMERS; STANLEY, 2016).

Há duas formas clássicas de pênfigo: pênfigo vulgar (PV) e pênfigo foliáceo $(\mathrm{PF})$, os quais apresentam autoanticorpos contra diferentes antígenos, afetando assim diferentes níveis da epiderme. O PF se caracteriza imunologicamente pela produção de autoanticorpos contra a Desmogleína (Dsg) 1, manifestando-se histologicamente por bolha superficial, abaixo da camada córnea - acantólise subcórnea. Por outro lado, o PV se caracteriza imunologicamente pela produção de autoanticorpos contra a Dsg3, proteína distribuída mais abundantemente nas camadas profundas da epiderme, com formação de bolha acima da camada basal - acantólise suprabasal. O PV também pode apresentar produção simultânea de autoanticorpos contra Dsg1 e Dsg3, acarretando envolvimento mucocutâneo (KASPERKIEWICZ et al., 2017).

O PF subdivide-se em dois tipos: [a] a forma clássica não endêmica: “de Cazenave”; e [b] uma forma endêmica - Pênfigo Foliáceo Endêmico, também conhecido no Brasil como "Fogo Selvagem". Ambos diferem quanto à epidemiologia: enquanto o pênfigo de Cazenave é esporádico ao redor do mundo e afeta principalmente a idade adulta, a forma endêmica se apresenta de maneira peculiarmente concentrada em focos geográficos definidos e incide maioritariamente nos adultos jovens (ALPSOY; AKMAN-KARAKAS; UZUN, 2015; MEYER et al., 2010).

A patogênese do PF é complexa e multifatorial, envolvendo fatores genéticos, imunológicos e ambientais (ABREU-VELEZ et al., 2010; AOKI, et al, 2015; QIAN et al., 2016). Considerando os fatores genéticos, alelos $H L A$ de classes I e II estão sabidamente envolvidos na patogênese dos pênfigos, sendo claramente identificados os alelos e haplótipos de suscetibilidade/proteção ao desenvolvimento do PF (BROCHADO et al., 2016; FRANCO BROCHADO et al., 2016). Em contraparte, os fatores imunológicos ainda não são totalmente esclarecidos. Acredita-se que a ligação dos autoanticorpos IgG às Dsgs ativaria uma serie de mecanismos sinérgicos no processo de acantólise, os quais estariam caracterizados por: [a] inibição direta da transinteração homofílica Dsg-Dsg, gerando perda da ligação entre elas; [b] internalização das Dsgs, diminuindo sua expressão na superfície dos queratinócitos; e [c] ativação de diferentes vias de sinalização, 
enfraquecendo a adesão celular (HAMMERS; STANLEY, 2016; KASPERKIEWICZ et al., 2017). Já, os fatores ambientais envolvidos na etiopatogênese do PF continuam sendo investigados. Fatores ambientais, como infecções virais (MACHADO et al., 2017), exposição a contaminantes hídricos e/ou agrícolas (CELERE et al., 2017; LA SERRA et al., 2019), doenças infecto-parasitárias (DIAZ et al., 2004; SOUSA, et al., 2012; WALSH et al., 2017) e picadas de insetos (EATON et al., 1998; LOMBARDI, et al., 1992; WAMBIER et al., 2017) têm sido propostos como potenciais iniciadores da resposta autoimune no PF.

A possível implicação de que insetos vetores estejam relacionados à etiopatogênese do $\mathrm{PF}$ vem sendo mencionada desde 1940 (ARANHA-CAMPOS, 1942; VIEIRA, 1940). A própria endemicidade da doença e a existência de focos geograficamente definidos, principalmente em áreas rurais próximas de fontes hidrográficas, demonstra a importância dos fatores ambientais (ABREU-VELEZ et al., 2010; AOKI, et al, 2015; DIAZ, et al., 1989). Desde os primeiros estudos sobre PF endêmico no Brasil, levantou-se a suspeita da participação de insetos antropofílicos na gênese da doença, particularmente Simulium nigrimanum (DIAZ et al., 1989; EATON et al., 1998; LOMBARDI et al., 1992). Inicialmente, considerou-se a possibilidade destes insetos atuarem como vetores de infecções particularmente virais. Ao longo do tempo, os estudos afastaram a origem viral e, com o conhecimento dos autoanticorpos anti-Dsg1, formulou-se a hipótese de mimetismo antigênico, isto é, admite-se a possibilidade dos Simulídeos, ou mesmo outros insetos, ao picarem o indivíduo, introduzirem através da saliva antígenos que despertariam a formação de anticorpos que reagiriam cruzadamente com a Dsg1 (LOMBARDI et al., 1992). Assim sendo, exposições repetidas ao antígeno em pacientes cronicamente expostos à picada de insetos desencadeariam uma resposta autoimune em indivíduos geneticamente predispostos (AOKI et al., 2015; QIAN et al., 2016).

Embora S. nigrimanum tenha sido por muitos anos o principal "suspeito" na etiopatogênese do $\mathrm{PF}$, nas últimas duas décadas os flebotomíneos surgem como um novo fator ambiental associado ao PF no Brasil (ROSELINO et al., 2001). Mantendo o conceito de que proteínas salivares produziriam reação cruzada com a Dsg1, e já considerando os avanços da biologia molecular com a consequente caracterização dos sialomas (transcriptomas das glândulas salivares) de insetos hematófagos de importância médica, dois peptídeos salivares emergem como potencias candidatos: Maxadilan (ROSELINO et al., 2001) e LJM11 (QIAN et al., 2012), duas proteínas altamente imunogênicas presentes na saliva do flebotomíneo Lutzomyia longipalpis (LERNER et al., 1991; VALENZUELA et al., 2004). 
O propósito desse estudo, constituindo o subprojeto VIII do projeto temático FAPESP 2010/51729-2, visou avaliar os fatores ambientais envolvidos na etiopatogênese do PF em amostra brasileira, focando na eventual participação das proteínas salivares dos insetos hematófagos presentes na região de estudo - a região nordeste do estado de São Paulo, Brasil. 
Revisão Bibliográfica 


\section{REVISÃO BIBLIOGRÁFICA}

\subsection{CONCEITOS GERAIS}

\subsubsection{O DESMOSSOMO}

O desmossomo (do grego "desmos"=ligação, e "somatos"=corpo) é uma estrutura celular especializada responsável pela adesão célula-célula. Os desmossomos se encontram localizados de maneira aleatória na membrana plasmática dos queratinócitos - as células diferenciadas do tecido epitelial - sendo constituídos por: [a] um domínio intracelular que outorga ancoragem na célula mãe, e por [b] um domínio extracelular que permite a união com a célula vizinha. O sistema de ancoragem está principalmente constituído por proteínas da família "armadilho", as quais proporcionam acoplamento adequado com os filamentos de queratina da célula de origem. Assim, os filamentos se ligam às Desmoplaquinas, que por sua vez se conectam à estrutura circular citoplasmática constituída por Placofilinas e Placoglobinas, uma em cada célula. A partir dessas placas, surgem duas glicoproteínas da família das caderinas, que atravessam a membrana plasmática e atingem o espaço extracelular alcançando as caderinas da célula vizinha. Tanto Desmogleínas (Dsg) como Desmocolinas (Dsc), caracterizam-se por formar enlaces rígidos, cálcio dependentes, através de interações heterofílicas com seus pares contralaterais (Figura 1) (KITAJIMA, 2014; KOTTKE et al., 2006).

\subsubsection{OS PENNFIGOS}

O termo pênfigo (do grego "pemphix"=bolha) refere-se a um grupo heterogêneo de dermatoses bolhosas crônicas autoimunes que podem afetar tanto a pele como membranas mucosas. Os pênfigos se caracterizam imunologicamente pela produção de autoanticorpos principalmente da classe IgG contra proteínas do desmossomo; histopatologicamente pela presença de acantólise intraepidérmica secundária ao depósito dos autoanticorpos nas Dsg; e clinicamente pela formação de lesões bolhosas na pele e/ou mucosas (KASPERKIEWICZ et al., 2017; POLLMANN et al., 2018).

Os pênfigos podem ser divididos em seis tipos: pênfigo vulgar (PV), pênfigo foliáceo (PF), pênfigo vegetante, pênfigo eritematoso, pênfigo paraneoplásico e pênfigo induzido por drogas 
(RUOCCO et al., 2013), sendo os mais comuns (chamados de clássicos) o PV e o PF (AMAGAI et al., 2015). Nos pênfigos clássicos, os autoanticorpos são da classe IgG - geralmente do subtipo $\mathrm{IgG}_{4}$ na atividade da doença - contra componentes extracelulares do desmossomo, principalmente as Dsgs. O PV caracteriza-se imunologicamente pela produção de autoanticorpos contra a Dsg3 ou de maneira simultânea contra Dsg1 e Dsg3, tendo como manifestação acometimentos mucoso e mucocutâneo. Por outro lado, o PF se caracteriza imunologicamente pela produção de autoanticorpos contra a Dsg1, levando a manifestações exclusivamente cutâneas (KASPERKIEWICZ et al., 2017).

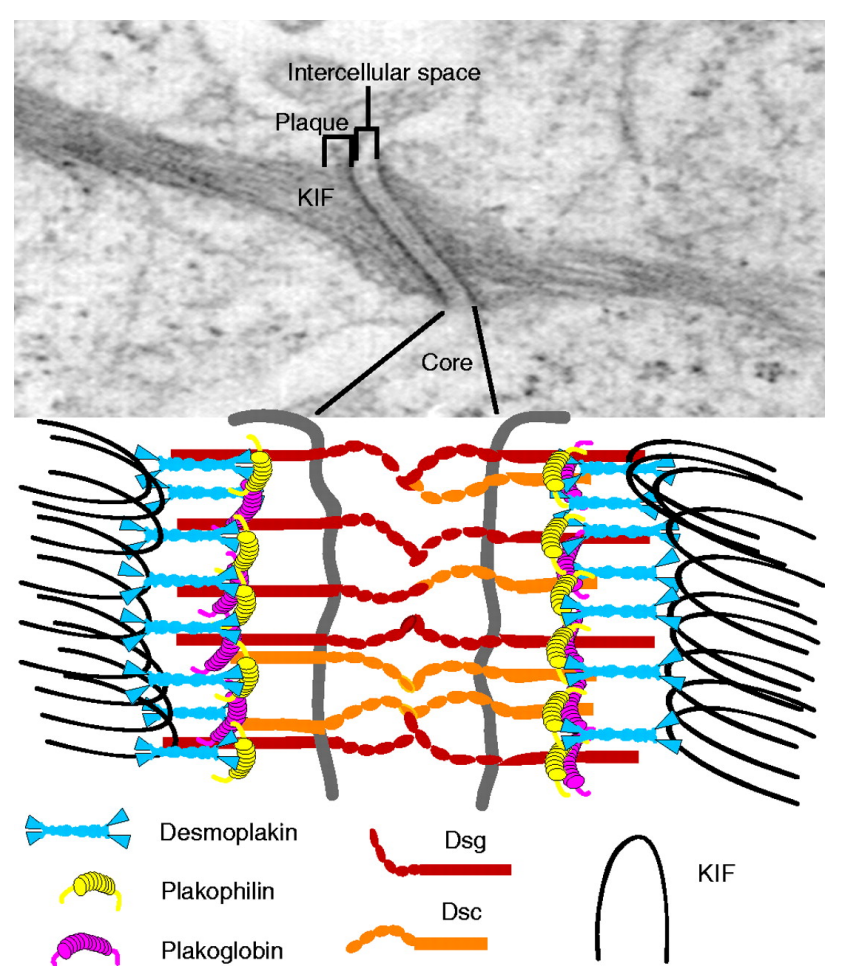

Figura 1. Estrutura microscópica e representação esquemática do Desmossomo. Microscopia eletrônica evidenciando o Desmossomo seguido de representação esquemática dos diferentes componentes envolvidos na adesão celular. Dsg=Desmogleínas; Dsc=Desmocolinas; KIF=filamentos intermédios de queratina. Fonte: KOTTKE et al., 2006.

Embora apresentado em todo o mundo, a prevalência dos pênfigos é influenciada pela localização geográfica e etnia. A incidência anual dos pênfigos varia de país a país, de 0,76 a 16,1 casos por milhão de habitantes por ano, sendo o PV o mais comum dos pênfigos na maioria das populações (AMAGAI et al., 2015; ALCAIDE-MARTIN et al., 2010; FEMIANO, 2007; JOLY et al., 2011; KRIDIN et al., 2017; MEYER et al., 2010). As maiores taxas de PV foram documentadas em populações com ascendência judaica (judeus Ashkenazi) - sudeste da Europa e o Oriente Médio. No entanto, na África do Norte, Tunísia e América do Sul, a prevalência de PF é superior ao PV 
(AMAGAI et al., 2015; CHACÓN et al., 2012; JOLY et al., 2011; KRIDIN et al., 2017; MEYER et al., 2010).

\subsection{O PÊNFIGO FOLIÁCEO ENDÊMICO}

O PF é subdividido em [a] PF clássico (também chamado de pênfigo "de Cazenave") e [b] PF endêmico (conhecido no Brasil como "Fogo selvagem"). Ambas formas de PF compartilham a mesma imunopatogênese, caracterizada pela presença de autoanticorpos anti-Dsg1, mas diferem em seus padrões epidemiológicos e de distribuição (ABREU-VELEZ et al., 2010; CHACÓN et al., 2012). Enquanto o PF clássico é observado ao redor do mundo esporadicamente sem evidência de agrupamentos geográficos, sua forma endêmica tem sido descrita principalmente na América Latina, com focos geográficos claramente identificados no Brasil (DIAZ et al., 1989) (Figura 2), Colômbia (ABREU-VELEZ et al., 2003), Peru (ORTEGA-LOAYZA et al., 2013), Paraguai (ALDAMA et al., 1996) e Venezuela (GONZÁLEZ et al., 2006); e também em alguns países do norte da África (SALEH, 2015), com aglomerados definidos na Tunísia (BASTUJI-GARIN et al., 1995).

\subsubsection{EPIDEMIOLOGIA DO PÊNFIGO FOLIÁCEO ENDÊMICO}

Em algumas regiões endêmicas de ameríndios, no Estado do Mato Grosso do Sul, a prevalência de PF varia entre 1,3\% e 3\% (FRIEDMAN et al., 1995; HANS-FILHO et al., 1996). Assim, o Brasil apresenta a maior incidência de PF em todo o mundo (25-35 casos/milhão de habitantes/ano) (CHAGAS et al., 2005; DIAZ et al., 1989), seguida pela da Tunísia (6,7 casos/milhão de habitantes/ano) (BASTUJI-GARIN et al., 1995).

Atualmente, os principais focos da doença estão localizados nos estados de Goiás, Distrito Federal, Mato Grosso, Mato Grosso do Sul, Minas Gerais, Paraná e São Paulo. No Estado de São Paulo, os municípios de Franca e Ribeirão Preto, foram os que apresentaram a maior prevalência de PF (CELERE et al., 2017; CHIOSSI et al., 2001; ABRÉU-VELEZ et al., 2010). Embora seja aceita a alta prevalência do PF no Brasil, uma série histórica de 21 anos confirmou o aumento da incidência do PV, ultrapassando a incidência do PF desde 1998 (GONÇALVES et al., 2011). Além deste aumento na incidência do PV, também há descrição de mudanças nos padrões 
epidemiológicos, semelhantes ao PF, configurando uma nova variante de PV endêmico (CELERE, et al., 2017; CHACÓN et al., 2012; ROCHA-ALVAREZ et al., 2007).

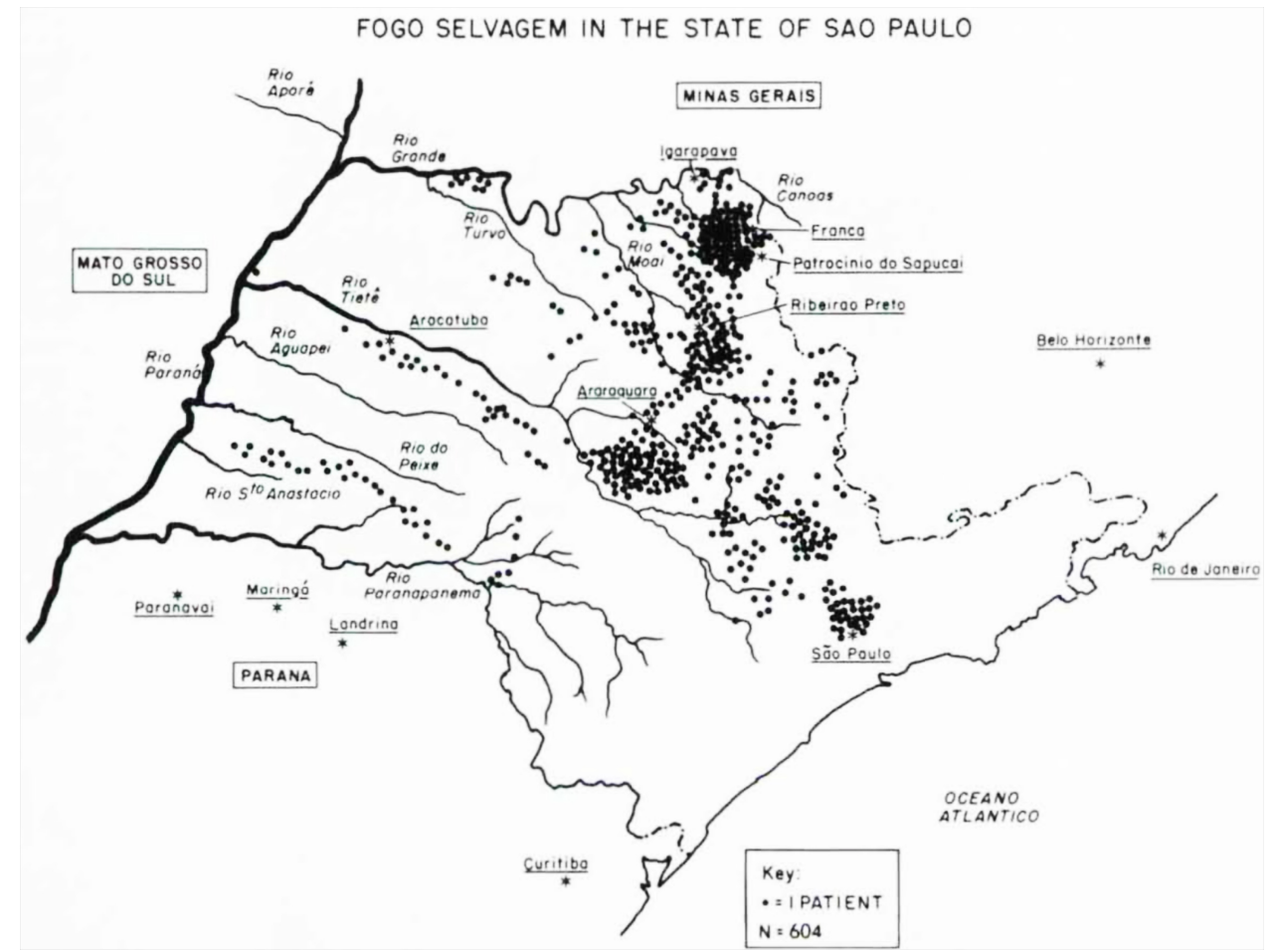

Figura 2. Focos de Pênfigo Foliáceo endêmico no Estado de São Paulo. Representação esquemática do estado de São Paulo identificando os casos de pênfigo foliáceo endêmico (pontos pretos). Observa-se a distribuição geográfica (próximos de bacias hidrográficas) e em conglomerados principalmente na cidade de Franca, Ribeirão Preto e Araraquara. Fonte: DIAZ et al., 1989.

\subsection{ETIOPATOGÊNESE DO PÊNFIGO FOLIÁCEO ENDÊMICO}

A etiopatogênese do PF ainda não é totalmente esclarecida, porém tem sido amplamente estudada nos últimos anos, envolvendo fatores genéticos, imunológicos e ambientais (ABREUVELEZ et al., 2010; AOKI, et al, 2015; QIAN et al., 2016).

\subsubsection{FATORES GENÊTICOS}

Igualmente a outras doenças autoimunes, o PF tem sido associado a genes do complexo maior de histocompatibilidade (MHC - Major Histocompatibility Complex). O MHC corresponde a um segmento genômico localizado na região 6p21.3 no braço curto do cromossomo 6, o qual codifica glicoproteínas de membrana especializadas na apresentação antigênica e resposta imune. 
Nos seres humanos, são denominados de antígeno leucocitário humano (HLA - Human Leukocyte antigen) e apresentam extenso polimorfismo, sendo cada variante denominada como alelo (KELLY et al., 2019).

Os genes codificados pelo MHC podem ser classificados em três classes de acordo com sua estrutura e função. As classes de $H L A$ mais estudadas no PF são: classe I - $H L A-A, B$ e $C$; e as de classe II - HLA-DR, DQ e DP (BROCHADO et al., 2016; KASPERKIEWICZ et al., 2017). Tanto na Tunísia como no Brasil, os alelos relacionados à susceptibilidade ou proteção para o desenvolvimento de PF tem sido claramente identificados (ABIDA et al., 2009; BROCHADO et al., 2016).

No Brasil, os alelos HLA-DRB1*01:01, *01:02, *01:03, *04:04, *04:06, *04:10, *14:06 e *16:01 têm sido associados à suscetibilidade ao $\mathrm{PF}$, enquanto o alelo $H L A-D Q B 1 * 02: 01$ tem sido associado à proteção ao PF (BROCHADO et al., 2016). Há poucos estudos que associam pênfigos aos alelos $H L A$ de classe I e a significância desses achados ainda não está totalmente esclarecida (SINHA, 2011). No Sudeste do Brasil, os genes $H L A$ de classe I - $H L A-A^{*} 11 / 33$ e $-B * 14$ foram associados à suscetibilidade, e $H L A-A^{*} 02$ à proteção ao $\mathrm{PF}$. Os haplótipos associados à suscetibilidade ao PF foram $H L A-D R B 1 * 04-D Q A 1 * 03-D Q B 1 * 04,-D R B 1 * 01-D Q A 1 * 01-D Q B 1 * 05$ e $-D R B 1 * 16-D Q A 1 * 01-D Q B 1 * 05$ enquanto o $-D R B 1 * 11-D Q A 1 * 05-D Q B 1 * 03$ à proteção ao $\mathrm{PF}$ (FRANCO BROCHADO et al., 2016; BROCHADO et al., 2016).

\subsubsection{FATORES IMUNOLÓGICOS E MECANISMOS DE ACANTÓLISE}

As Dsgs (do grego "desmos"=nó e "glein"=semelhante à cola) são um grupo de proteínas pertencentes à família das caderinas, responsáveis pela ligação extra-citoplasmática do desmossomo. Há quatro isoformas de Dsgs: Dsg1, Dsg2, Dsg3 e Dsg4. A Dsg2 é expressa em todos os tecidos que têm desmossomos, incluindo epitélios simples e miocárdio, enquanto a expressão de Dsg1 e Dsg3 está restrita ao epitélio escamoso estratificado. A Dsg1, proteína de $160 \mathrm{kDa}$, localiza-se preferencialmente nas camadas mais superficiais da epiderme (KASPERKIEWICZ et al., 2017; POLLMANN et al., 2018)

As Dsgs são expressas como pró-peptídeos, isto é, como proteínas precursoras (inativas) que sofrem modificação pós-transducional. Logo da sua maturação, com cerca de 26 resíduos, as Dsgs são clivadas na superfície da membrana celular pela porção N-terminal, que promove a interação intercelular, seguida de uma hélice de transmembrana para finalmente se unir à placa desmossômica 
citoplasmática pela porção C-terminal. Assim, o segmento extracelular apresenta cinco domínios (EC1 a EC5) (Figura 3) (KITAJIMA, 2014; KOTTKE et al., 2006; YOKOUCHI et al., 2009).

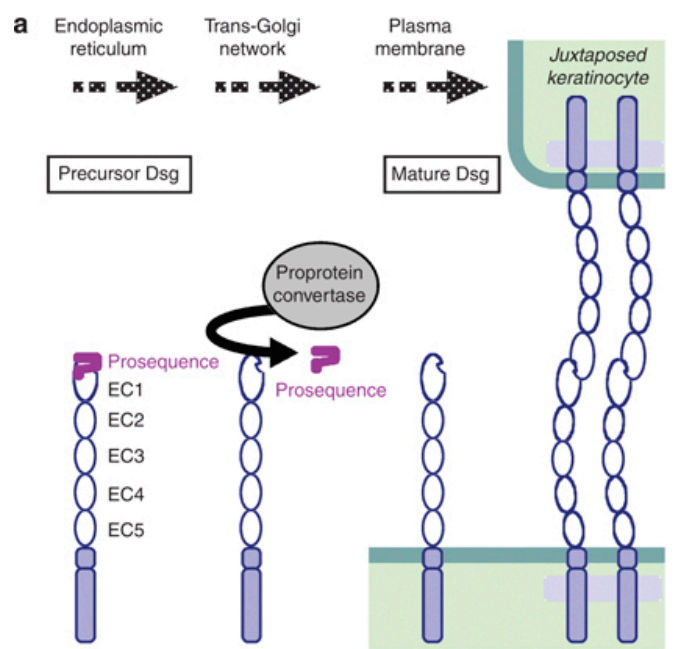

Figura 3. Maduração e clivagem das Desmogleínas. De esquerda à direita: a expressão do pro-peptídeo (precursor da Desmogleína 1 com os domínios extracelulares EC1 - EC5) seguido da maturação e pós clivagem no desmossomo. Fonte: YOKOUCHI et al., 2009.

As extremidades amino-terminais das Dsgs expressam epítopos importantes para a patogenicidade do PF. Sabe-se que o soro de pacientes com PF na fase pré-clínica reconhece epítopos na porção terminal COOH do domínio EC5 da Dsg1. O início da fase clínica da doença está associado ao surgimento de anticorpos específicos para epítopos das porções terminais $\mathrm{NH} 2$ dos domínios EC1 e EC2. Quando há remissão da doença, nota-se aumento da dosagem de autoanticorpos que reconhecem o domínio EC5 da Dsg1, sugerindo que a variação na expressão desses epítopos possa estar relacionada aos episódios de remissão e recorrência da doença. Assim, a soroconversão de indivíduo saudável para doente seria caracterizada pela modificação do perfil das imunoglobulinas - de IgG contra o epítopo EC5 na fase pré-clínica para $\operatorname{IgG}_{4}$ reconhecendo os domínios EC1 e EC2 - fenômeno denominado de epitope spreading (Figura 4) (HANS-FILHO et al., 1996; QIAN et al., 2009; LI et al., 2003).

Para comprovar a patogenicidade na mudança desse perfil sorológico, anticorpos anti-Dsg1 da classe $\operatorname{IgG}_{1}$ foram transferidos passivamente para camundongos recém-nascidos, evidenciando não haver desenvolvimento do PF; ao contrário, a transferência passiva de anti-Dsg $\mathrm{IgG}_{4}$ levou ao desenvolvimento de acantólise subcórnea (CULTON et al., 2008).

Nos pênfigos, pode ocorrer discordância entre os perfis clínicos e sorológicos em cerca de um terço dos casos (SARDANA et al., 2013). Esta observação, e o conhecimento de que a presença de autoanticorpos anti-Dsg1 e anti-Dsg3 não resulta em completa dissolução do epitélio, sugere que 
outros fatores contribuam para o desenvolvimento do pênfigo. Nos últimos anos há ênfase no papel de antígenos desmossomais diferentes da Dsg como causadores de pênfigos, aumentando consideravelmente o número de novas moléculas estudadas. Alguns exemplos são as Desmoplaquinas, receptores de acetilcolina dos queratinócitos, Dscs, colágeno XVII, além de outras moléculas relacionadas à alteração celular que resultam em acantólise (CIRILLO, 2013).

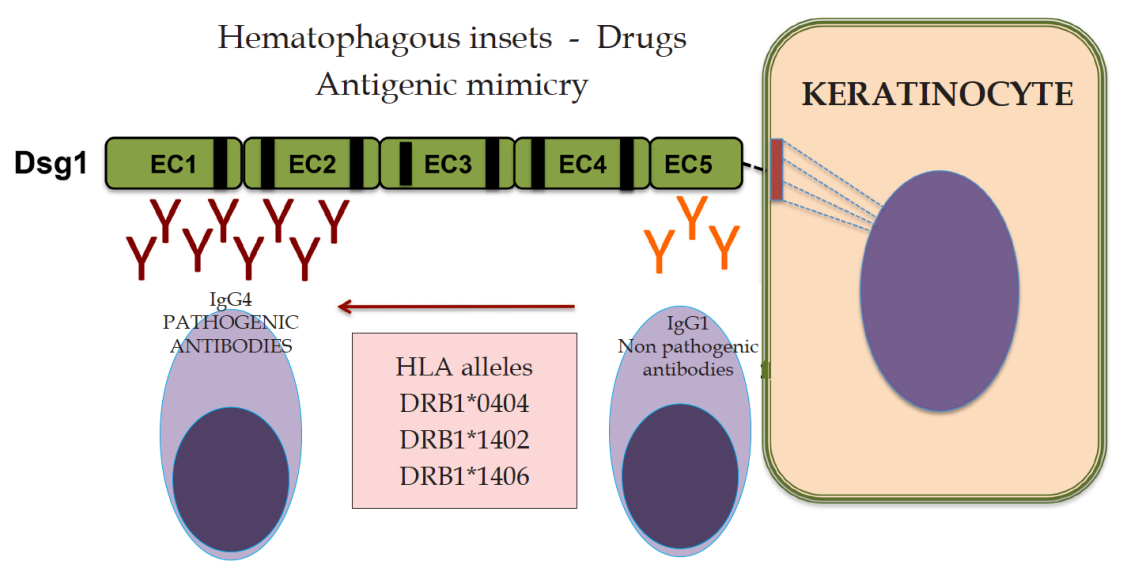

Figura 4 - Etiopatogênese do pênfigo foliáceo endêmico. Representação esquemática do queratinócito com destaque na Desmogleína 1 incluindo os domínios extracelulares EC1 - EC5. Anticorpos do subtipo $\operatorname{IgG}_{1}$ (nos patogênicos representados em laranja) contra o domínio EC5. Observa-se a mudança no perfil sorológico devido a fatores genéticos (alelos HLA de susceptibilidade) e ambiente, levando a produção de autoanticorpos do tipo $\operatorname{IgG}_{4}$ (patogênicos representados em vermelho) contra o domínio EC1. Fonte: HANS-FILHO et al., 2018

Outros dados que suportam o envolvimento de outros fatores na patogênese do pênfigo são as mudanças nos padrões epidemiológicos e clínicos do PF. Têm sido descritos anticorpos circulantes anti-Dsg1 em indivíduos saudáveis - em familiares de indivíduos acometidos pelo PF ou em moradores de áreas endêmicas. Há casos de transição de fenótipos de PF para PV e vice-versa, com expressão de anticorpos anti-Dsg1 no PV, e anti-Dsg3 no PF, e fenótipo de PV em área endêmica para PF (ROCHA-ÁLVAREZ et al., 2007). Estes dados, aliados ao aumento progressivo dos níveis de anticorpos anti-Dsg1 de acordo com a proximidade do foco endêmico de PF, suportam a hipótese da associação de um agente ambiental na patogênese da doença (WARREN et al, 2000; DIAZ et al, 2008).

Os mecanismos da acantólise nos pênfigos ainda permanecem desconhecidos. Inicialmente, a perda da tolerância à Dsg1 é estabelecida por ocasião da exposição imunológica do peptídeo (ou parte dele) aos linfócitos $\mathrm{Th}_{2}$ pelas células apresentadoras de antígenos (células de Langehans e células dendríticas), mediado por alelos HLA relacionados à susceptibilidade da doença, e 
consequentemente na produção de autoanticorpos pelos linfócitos B (HEUPEL, 2008; KASPERKIEWICZ et al., 2017; POLLMANN et al., 2018; SHARMA; MAO; PAYNE, 2007).

Estudos com modelos experimentais em ratos, culturas de queratinócitos humanos e biópsias de pele de pacientes com pênfigo sugerem que a ligação dos autoanticorpos nas Dsgs podem gerar acantólise por diversos mecanismos sinérgicos. O primeiro deles seria devido à inibição direta da união Dsg-Dsg por bloqueio mecânico da transinteração homofílica ("steric hindrance") gerando perda da ligação entre elas. Apesar disso, esse mecanismo não explicaria totalmente o processo de acantólise, considerando que a dissociação do enlace Dsg-Dsg pode ocorrer sem bloquear a transinteração homofílica da Dgs1 (Figura 5) (HEUPEL, 2008; KASPERKIEWICZ et al., 2017; POLLMANN et al., 2018; SHARMA et al., 2007).

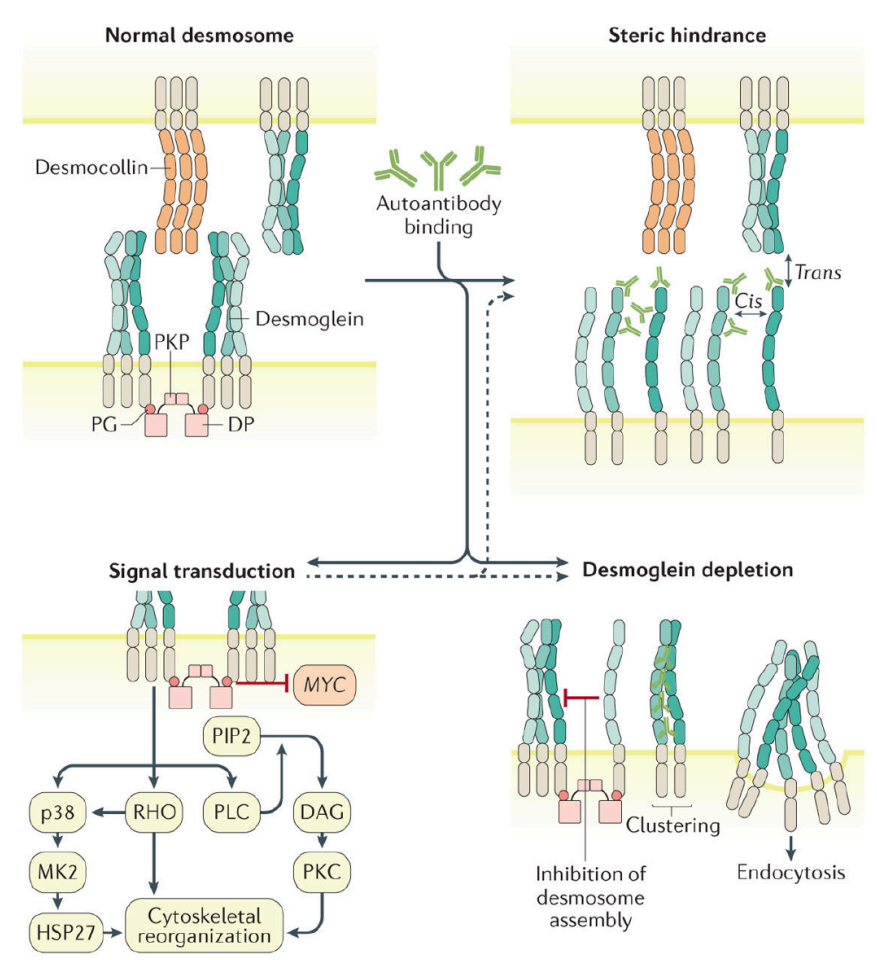

Figura 5. Mecanismo de acantólise nos pênfigos. Acima à direita observa-se a estrutura normal do desmossomo. Em seguida mostra acima à direita e embaixo os três mecanismos que explicariam o proceso de acantólise, incluindo o bloqueio mecânico (steric hindrance), a depleção de Desmogleínas devido a fenômenos de agrupação e internalização, e a ativação de vías de sinalização que contribuiriam com o enfraqueciemento dos enlaces. Fonte: KASPERKIEWICZ et al., 2017.

Assim, o mecanismo de acantólise por steric hindrance passou a ser complementado por uma nova hipótese, a qual se baseia na capacidade dos autoanticorpos anti-Dsg1 agruparem e redistribuírem a Dsg1 no desmossomo. A formação de cluster e a internalização das Dsgs levariam à depleção das caderinas no desmossomo, evitaria a incorporação de novas Dsgs sendo produzidas, 
dificultando a adesão celular pela falta da expressão de Dsg1 na superfície dos queratinócitos (HAMMERS; STANLEY, 2016; KASPERKIEWICZ et al., 2017; SPINDLER et al., 2014).

Além destes dois mecanismos, numerosas moléculas de sinalização e vias metabólicas têm sido implicadas na acantólise nos pênfigos: p38 mitogen-activated protein kinase e seu efetor; Epidermal growth factor receptor; RHO GTPases; c-MYC; fosfolipase C e sua forma ativada fosfoquinase C, e caspases. Entretanto, nenhum evento de sinalização é suficiente para induzir acantólise epidérmica/ porém contribuem no enfraquecimento da adesão celular (HAMMERS; STANLEY, 2016; KASPERKIEWICZ et al., 2017; SPINDLER et al., 2014).

\subsubsection{FATORES AMBIENTAIS}

Fatores genéticos isolados não são suficientes para causar os pênfigos, e desencadeantes ambientais parecem ter papel na indução e/ou exacerbação da doença (MARTINELLI et al., 2016). Os fatores ambientais envolvidos na etiopatogênese do PF continuam sendo investigados. Do ponto de vista imunológico, a maioria dos agentes que estimulam o sistema imune pode atuar como gatilhos à autoimunidade, tais como alterações hormonais, medicamentos, doenças, alimentos, estresse emocional, gestação, entre outros (TAVAKOLPOUR, 2017)

No sudeste brasileiro, os fatores ambientais associados ao PF têm sido amplamente estudados, incluindo infecções virais (MACHADO et al., 2017), estresse (MATIAS; ROSELINO, 2013), exposição a contaminantes hídricos e/ou agrícolas (CELERE et al., 2017; LA SERRA et al., 2019), doenças infecto-parasitárias (DIAZ et al., 2004; SOUSA, et al., 2012; WALSH et al., 2017) e picadas de insetos (EATON et al., 1998; LOMBARDI, et al., 1992; WAMBIER et al., 2017). Todos têm sido propostos como potenciais desencadeantes da resposta autoimune no PF.

A expansão das fronteiras urbanas com a consequente invasão das florestas (principalmente devido ao agronegócio da cana e às plantações de café no estado de São Paulo) apresentou novo estágio de convivência com a fauna local anteriormente confinada fora das cidades. Há maior exposição às picadas de insetos hematófagos, levando ao aumento de inúmeras doenças anteriormente restritas às atividades rurais (por exemplo, leishmaniose, uma doença transmitida por picada de flebotomíneos) (TOLEZANO, 1994). É nesse cenário que os focos geográficos dos casos de PF começam a aparecer, especialmente bacias hidrográficas ao redor, levando a suspeitar que um ambiente local possa estar envolvido na etiopatogênese do PF (AOKI et al., 2015). 


\subsection{ALERGIA E AUTOIMUNIDADE}

Anticorpos da classe $\operatorname{IgE}$ têm sido tradicionalmente relacionados a reações alérgicas por hipersensibilidade tipo 1. Nos últimos anos, a detecção de anticorpos IgE antinucleares na artrite reumatoide e no lúpus eritematoso sistêmico permitiram a hipótese de que os fenômenos alérgicos poderiam ter papel fisiopatológico na autoimunidade (ETTINGER et al., 2017; MURO, 2001). Tanto a alergia como a autoimunidade são resultados de disfunção do sistema imunológico. Embora os processos patológicos sejam diferentes, existem evidências de que as duas anormalidades poderiam compartilhar um processo fisiopatológico em comum (ROTTEM, 2002). Assim, condições alérgicas e autoimunes podem coincidir no mesmo paciente. Por exemplo, crianças com artrite reumatoide e doença celíaca têm maior incidência de asma (KERO et al., 2001; SIMPSON et al., 2002), e anticorpos IgE de pacientes com dermatite atópica podem reagir contra proteínas humanas (VALENTA et al., 1996; VALENTA et al., 2000). Outro mecanismo fisiopatológico em comum é que os alérgenos que a IgE visa em pacientes atópicos podem ser exógenos (alérgenos) ou endógenos (autoantígenos) (ETTINGER et al., 2017; MITTERMANN et al., 2004; VALENTA et al, 1997), além de vários outros alérgenos que exibem epítopos compartilhados com proteínas próprias do ser humano, por exemplo, infecções fúngicas ou pólen (CRAMERI et al., 1996; VALENTA et al., 1991).

Em relação às dermatoses bolhosas autoimunes, estudos com penfigóide bolhoso (PB) mostraram autoanticorpos elevados da classe IgE com papel fisiopatológico; de fato, uma revisão sistemática recente confirma que, quanto mais altos os níveis séricos de autoanticorpos IgE contra os alvos patogênicos do PB (BP180 e BP230), mais grave será a manifestação do BP (SANIKLIDOU et al., 2018). Da mesma forma, anticorpos IgE anti-Dsg3 no PV se correlacionam diretamente com autoanticorpos patogênicos $\mathrm{IgG}_{4}$ contra Dsg3, e se associam intimamente com a atividade da doença (NAGEL et al., 2010).

Outra ligação direta entre alergia e autoimunidade são os anticorpos envolvidos em ambos processos, $\operatorname{IgE}$ e $\mathrm{IgG}_{4}$, sendo esse último o principal anticorpo envolvido na patogênese das dermatoses bolhosas autoimunes, incluindo o PF (EVANGELISTA et al., 2018; QIAN et al., 2016). Reações alérgicas estão caracterizadas pela formação de anticorpos da classe IgE, mas com uma resposta paralela caracterizada pela formação de anticorpos $\mathrm{IgG}_{4}$ com o intuito de bloquear a resposta inflamatória induzida pelos alérgenos (ETTINGER et al., 2017; ROTTEM, 2002). Esse fato pode ser comprovado em estudos de imunoterapia, demonstrando valores séricos recíprocos de 
anticorpos $\operatorname{IgE}$ e $\operatorname{IgG}_{4}$, isto é, os níveis de $\operatorname{IgE}$ diminuíram à medida que os níveis de $\operatorname{IgG}_{4}$ aumentaram durante os meses após a imunoterapia (TRAMPERT et al., 2018). O papel da $\mathrm{IgG}_{4}$ na hipersensibilidade tem sido amplamente estudado na última década. Hipotetizou-se que $\operatorname{IgG}_{4}$ atuaria como bloqueador da resposta alérgica por três mecanismos: [I] competição com IgE por locais antigênicos nos alérgenos, [II] ligação de receptores Fc em células imunes (macrófagos, células B, neutrófilos, mastócitos e basófilos), desencadeando eventos imunomoduladores, e [III] comportando-se como anticorpos anti-idiotípicos, isto é, agindo contra o próprio IgE (Figura 6) (KONECZNY, 2018; LARCHE, 2007; STRAIT et al., 2006; TRAMPERT et al., 2018).

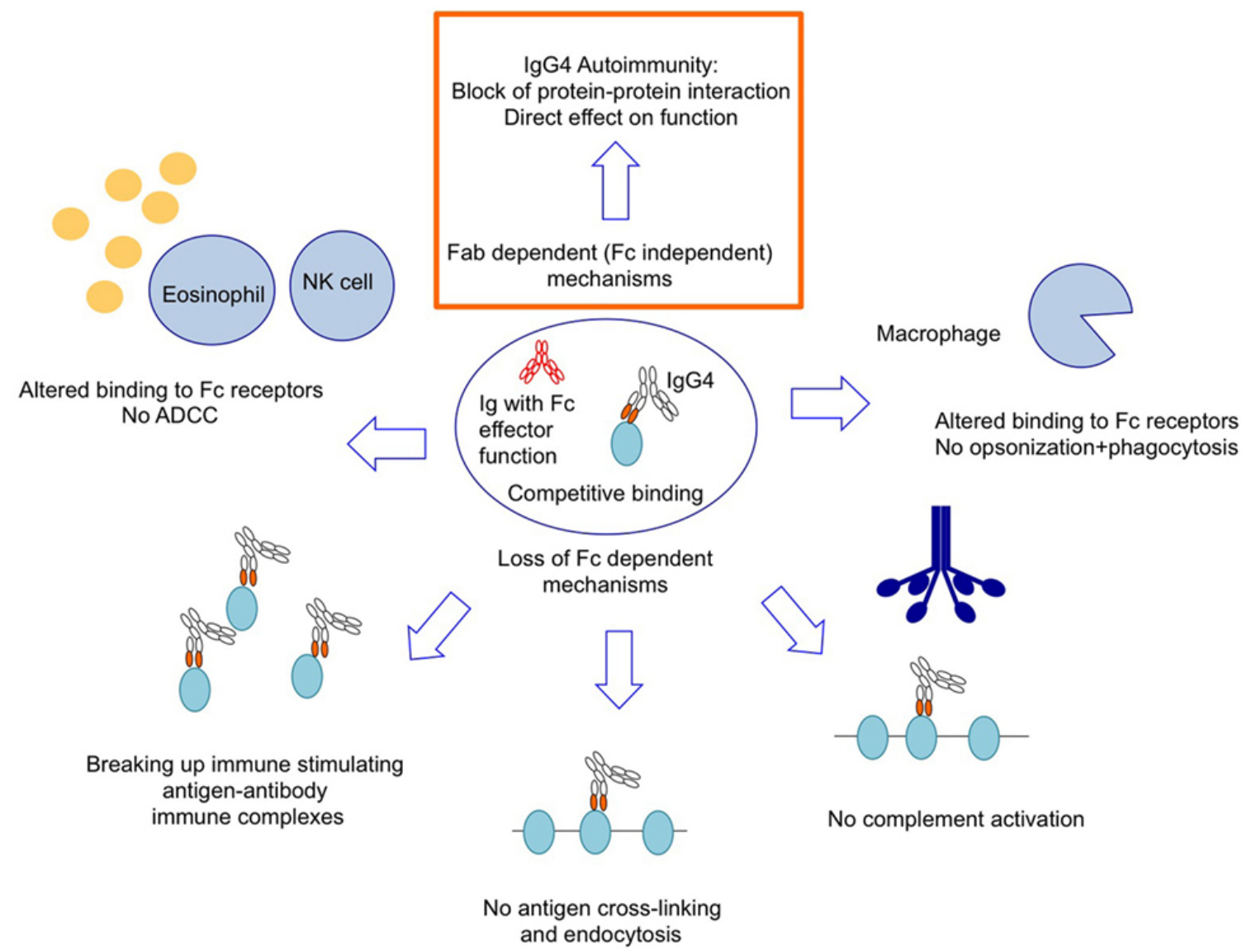

Figura 6. Papel dos anticorpos $\mathrm{IgG}_{4}$ na alergia e hipersensibilidade. Representação esquemática dos mecanismos pelos quais os anticorpos IgG4 participariam na resposta alérgica e de hipersensibilidade. Fonte: KONECZNY, 2018

A troca de classe supracitada estaria determinada por uma reposta $\mathrm{Th}_{2}$, sendo mediada principalmente pelas citocinas IL-4 e IL-13. No entanto, a estimulação antigênica crônica induz a secreção de IL-10, na tentativa de diminuir a inflamação provocada pelos alérgenos, porém que altera o equilíbrio da troca de classe em direção à $\mathrm{IgG}_{4}$ (JEANNIN et al., 1998). Desde o ponto de vista de hipersensibilidade, a intervenção de IL-10 apresenta um resultado benéfico ao paciente, 
mas em indivíduos geneticamente susceptíveis, esse processo pode desencadear uma resposta $\operatorname{IgG}$ mais robusta, levando à produção de $\mathrm{IgG}_{4}$ com atividade patogênica (Figura 7). Assim, é possível que um alérgeno ambiental desencadeie a resposta de IgE no PF, e os anticorpos direcionados contra esse antígeno externo reajam de maneira cruzada com a Dsg1 (QIAN et al., 2016).

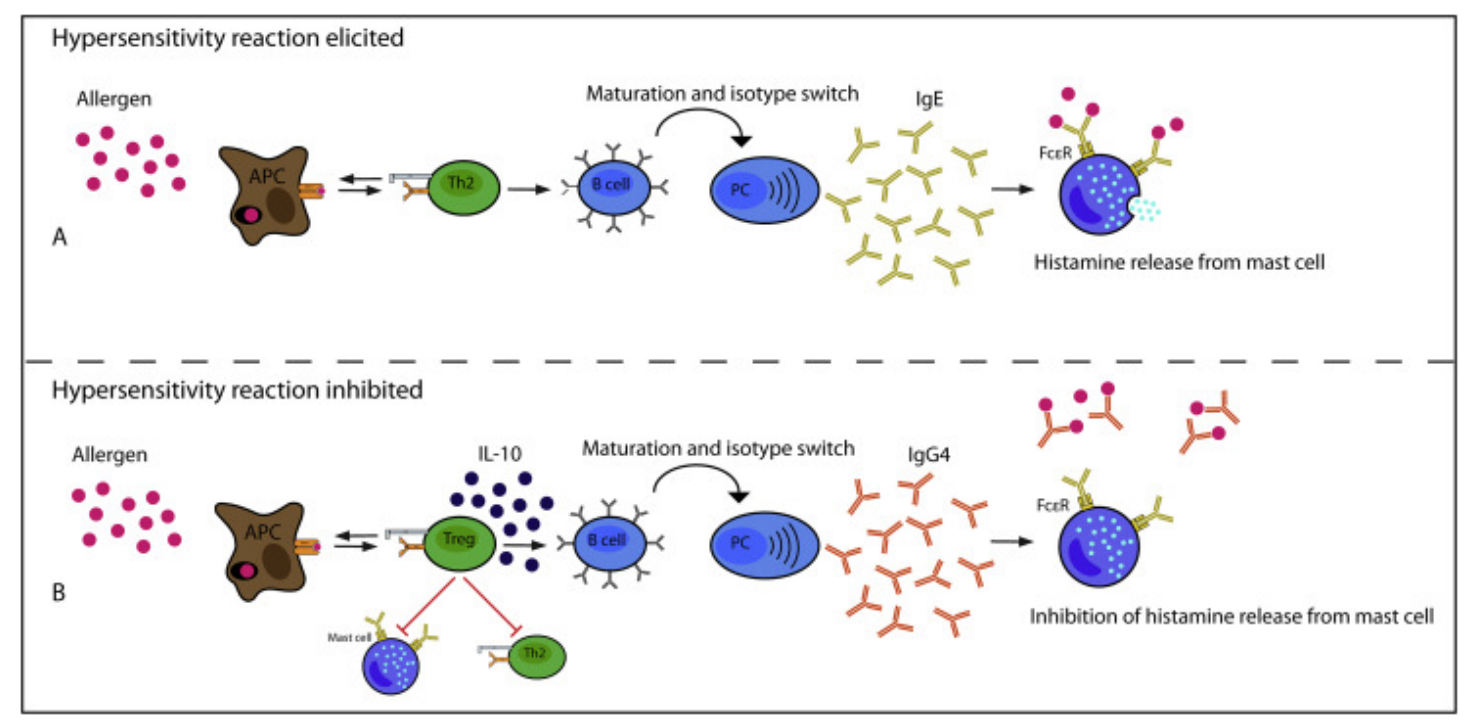

Figura 7. Evolução da resposta alérgica durante exposição crônica. Em fase aguda, o estímulo alérgico leva a uma resposta $\mathrm{Th}_{2}$ com uma produção de anticorpos maioritariamente do tipo $\operatorname{IgE}$ (acima). A exposição crônica dos alérgenos estimularia uma modulação por IL-10 visando uma redução dos efeitos imunológicos associados à hipersensibilidade associado a uma troca de classe para anticorpos do tipo $\mathrm{IgG}_{4}$. Fonte: TRAMPERT et al., 2018.

\subsubsection{PÊNFIGO FOLIÁCEO E IMUNOGLOBULINA E}

Considerando a endemicidade do PF em um contexto de países tropicais em vias de desenvolvimento (principalmente América Latina e o norte da África) (BASTUJI-GARIN et al., 1995; DIAZ et al., 1989), a presença de anticorpos IgE no PF foi atribuída a uma potencial infestação por parasitas intestinais (BRUNS et al., 1978). A potencial relação da alergia e autoimunidade nos últimos anos levou à hipótese de que altos níveis de IgE anti-Dsg1 em pacientes com PF poderia ser melhor explicado por uma exposição contínua a um antígeno (ou antígenos) sensibilizantes de origem ambiental, presente nas regiões em que esses pacientes vivem, que por infeções infecto-parasitárias per se (QIAN et al., 2016).

$\mathrm{Na}$ última década, estudos revelaram que pacientes com PF de áreas endêmicas do Brasil apresentavam níveis significativamente mais altos de anticorpos IgE anti-Dsg1 em comparação com pacientes com PF (“de Cazenave”) procedentes dos Estados Unidos e Japão. Os níveis de IgE antiDsg1 nesses pacientes brasileiros com PF estariam intimamente correlacionados aos autoanticorpos 
patológicos da classe $\mathrm{IgG}_{4}$ anti-Dsg1 (QIAN et al., 2011). Interessantemente, os níveis de IgE antiDsg1 de pacientes saudáveis moradores de áreas endêmicas também foram significativamente mais altos em comparação com paciente saudáveis que moravam em áreas não endêmicas fora do Brasil, sugerindo que existe um fator ambiental presente exclusivamente em regiões com alta incidência de PF (QIAN et al., 2011). Além disso, os títulos de IgE anti-Dsg1 de pacientes com PF aumentavam significativamente na transição da fase pré-clínica para a fase clínica da doença (QIAN et al., 2015).

\subsection{INSETOS HEMATÓFAGOS E O PÊNFIGO FOLIÁCEO ENDÊMICO}

Em 1940 Vieira descreveu o comportamento geográfico do PF no estado de São Paulo, mostrando vários focos claramente definidos, especialmente próximos aos rios e principalmente na região nordeste do estado. Vieira também apontou um vínculo epidemiológico entre S. nigrimanum (um inseto hematófago da família das moscas), e a endemicidade do PF (VIEIRA, 1940). Posteriormente, a relação epidemiológica entre borrachudos e o PF também foi confirmada em outros focos endêmicos, sendo evidenciada a presença de diferentes espécies de borrachudos incluindo S. nigrimanum (EATON et al., 1998). Além disso, as picadas de borrachudos também foram consideradas como um fator de risco para o desenvolvimento de PF (razão de risco de 4,7) em uma reserva indígena do Mato Grosso do Sul (LOMBARDI et al., 1992).

\subsubsection{PROTEÍNAS SALIVARES DE INSETOS HEMATÓFAGOS E DESMOGLEÍNA 1}

Doenças infecto-parasitárias são associadas à patogênese do PF. Oncocercose, Leishmaniose e a Doença de Chagas estão sendo relacionadas ao PF endêmico tanto no Brasil como na Tunísia. Os pacientes portadores dessas condições infecciosas também exibem autoanticorpos circulantes contra Dsg1 (DIAZ et al., 2004; KALLEL-SELLAMI et al., 2007; WALSH et al., 2017; ZARAA et al., 2012). Curiosamente, as três condições infecciosas supracitadas são transmitidas por insetos hematófagos vetores: Simulídeos, Flebotomíneos e Triatomíneos, respectivamente. Ressalta-se que os títulos de IgG anti-Dsg1 nessas três condições parasitárias são significativamente mais altas em comparação com outras infecções, tais como Blastomicose e Hanseníase (doenças infecciosas não vetoriais) (DIAZ et al., 2004), o que sugere que os componentes salivares de seus respectivos vetores poderiam ter participação na etiopatogênese do PF. 
No estado do Mato Grosso do Sul, pacientes com PF endêmico possuem anticorpos da classe $\mathrm{IgE} \mathrm{e} \mathrm{IgG}_{4}$ contra antígenos (extrato proteico total) da glândula salivar do flebotomíneo $\mathrm{Lu}$. longipalpis. Os níveis de $\mathrm{IgE}$ e $\mathrm{IgG}_{4}$ contra esse extrato salivar se correlacionam significativamente com os autoanticorpos $\mathrm{IgG}_{4}$ anti-Dsg1, sugerindo um fenômeno de "cross reaction" durante exposição crônica alérgica contra a picada desse inseto (QIAN et al., 2012).

\subsection{SIMULÍDEOS (BLACKFLIES)}

\subsubsection{CONCEITOS GERAIS DOS SIMULÍDEOS}

Pertencentes à família Simuliidae, os borrachudos ocupam a trigésima posição em número de espécies dentre as 130 famílias de Diptera (ADLER, 2004). De acordo com a última contagem, aproximadamente 2.151 espécies válidas estão descritas no planeta (ADLER, CROSSKEY, 2014), o que representa aproximadamente $2 \%$ do total de espécies de Dípteras descritas. Sua abundância, ampla distribuição geográfica, importância médica e econômica e, principalmente, as picadas nos humanos lhes garantem um privilegiado reconhecimento. Os borrachudos adultos são diurnos, ambos os sexos alimentam-se de néctar de plantas e flores, e somente as fêmeas de algumas espécies antropofílicas alimentam-se de sangue humano (ADLER, 2004; COSCARÓN; COSCARÓN-ÁRIAS, 2007).

\subsubsection{IMPORTÂNCIA MÉDICA DOS SIMULÍDEOS}

As fêmeas adultas de simulídeos estão entre os insetos hematófagos mais incômodos ao ser humano e outros animais. São de importância médica e veterinária por seu potencial como vetores de várias doenças transmitidas pelo carreamento de diversos agentes etiológicos, tais como, bactérias, helmintos, protozoários e vírus. Algumas espécies são incriminadas como vetores de Onchocerca volvulus e Mansonella ozzardi, agentes patogênicos da oncocercose ("cegueira de rio") e mansonelose, respectivamente (SHELLEY et al., 1976; SHELLEY et al., 1997; SHELLEY; COSCARÓN, 2001; MARTINS et al., 2010; REIDPATH et al. 2011).

No estado do Pará, Pinheiro et al. (1974) sugerem que a "Síndrome Hemorrágica de Altamira" (uma doença endêmica, caracterizada por púrpura petequial, equimoses e sufusões hemorrágicas, além de sangramento da mucosa oral e gastrointestinal) seja uma virose transmitida 
por simulídeos. Atualmente, considera-se o mecanismo do desencadeamento da síndrome desconhecido, porém, possivelmente relacionada à hipersensibilidade às substâncias contidas na saliva dos “piuns” (nome dos borrachudos no Pará) (PINHEIRO et al., 1974).

S. vittatum tem sido incriminado como vetor de vesículo vírus, New Jersey Virus, agente etiológico de dermatoses bolhosas em cavalos, porcos e vacas (ADLER et al., 2004).

\subsubsection{DISTRIBUIÇÃO DOS SIMULÍDEOS NO ESTADO DE SÃO PAULO.}

No Brasil, há registro de 91 espécies, sendo que 55 dessas espécies encontram-se no estado de São Paulo (PEPINELLI, 2003). Não existem estudos de organizações oficias governamentais em relação à distribuição dos borrachudos no Brasil (sem importância na saúde pública). No entanto, no ambiente acadêmico foi possível evidenciar a distribuição do S. nigrimanum na tese de doutorado do Dr. Mateus Pepinelli, Universidade de Campinas, São Paulo. Embora não existisse uma coleção sistemática envolvendo todos os municípios do estado, foi possível evidenciar o georreferenciamento desse inseto principalmente na região nordeste do estado de São Paulo, coincidentemente onde se localizam os principais focos geográficos de PF (Figura 8) (PEPINELLI, 2003).

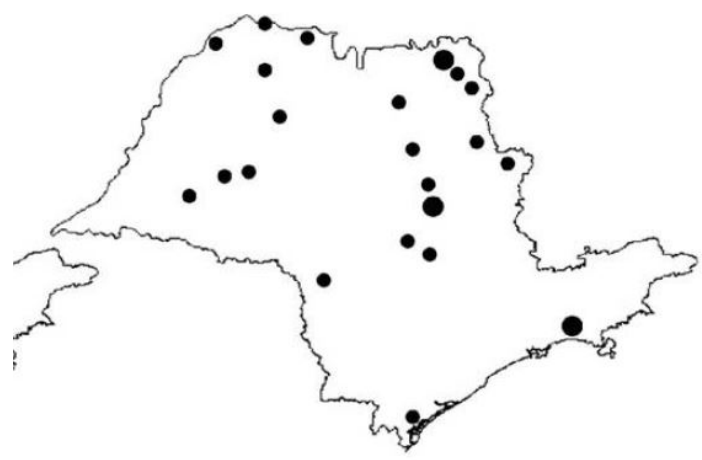

28-Simulium nigrimanum

Figura 8. Georreferenciamento da distribuição do Simulium nigrimanum no estado de São Paulo, Brasil. Locais de coleta positiva (pontos pretos) do borrachudo Simulium nigrimanum no estado de São Paulo, Sudeste Brasileiro. Fonte: PEPINELLI, 2003.

\subsubsection{PROTEÍNAS SALIVARES (SIALOTRANSCRIPTOMA) DO SIMULIUM NIGRIMANUM}

A identificação de possíveis antígenos salivares de Simulídeos com a capacidade de gerar o fenômeno de mimetismo molecular foi descrita pela análise do sialotranscritoma de S. nigrimanum. Proteínas salivares do S. nigrimanum - denominadas "Collagen-like" - evidenciaram semelhanças 
significativas com as Dsgs, porém essas proteínas ainda não foram testadas para avaliar possível reação cruzada com a Dsg1 (RIBEIRO et al., 2010). Com o mesmo intuito supracitado, considerando-se os títulos elevados de anti-Dsg1 na Doença de Chagas (DIAZ et al., 2004), o mesmo grupo também analisou a glândula salivar do Triatoma matogrossensis. A descrição do sialotranscritoma desta última espécie não revelou semelhança significante com as Dsgs (ASSUMPÇÃO et al., 2012).

\subsection{FLEBOTOMÍNEOS (SANDFLIES)}

\subsubsection{CONCEITOS GERAIS DOS FLEBOTOMÍNEOS}

Os flebotomíneos são insetos pequenos que pertencem à ordem Diptera (mesmo grupo das moscas, mosquitos, borrachudos e maruins), família Psychodidae, sub-família Phlebotominae. No Brasil, esses insetos podem ser conhecidos por diferentes nomes, de acordo com a sua ocorrência geográfica, como tatuquira, mosquito palha, asa dura, asa branca, cangalhinha, birigui, anjinho, entre outros. São conhecidas cerca de 900 espécies no mundo, das quais 470 estão distribuídas no continente Americano (GALATI, 2003), e 69 têm sido descritas no Estado de São Paulo (SHIMABUKURO, GALATI, 2010), sendo o gênero Lutzomyia responsável pela transmissão da Leishmaniose. Só as fêmeas sugam o sangue, necessário para completar seu ciclo reprodutivo. Sua picada costuma ser dolorosa, e pode transmitir várias espécies de Leishmania, tanto em florestas quanto em ambientes modificados, incluindo áreas urbanizadas ou só com vegetação arbustiva $\left(\mathrm{SUCEN}, 2015^{\mathrm{a}}\right)$.

\subsubsection{IMPORTÂNCIA MÉDICA DOS FLEBOTOMÍNEOS}

Existem registros de Leishmaniose Tegumentar Americana (LTA) no estado de São Paulo desde 1884. A expansão das plantações de café durante o século XIX provocou aumento da transmissão da LTA, produto do desmatamento que continuou crescendo durante o início do século $\mathrm{XX}$, chegando até a região noroeste do estado, pela construção de ferrovias para o transporte de grãos de café para a costa (TOLEZANO, 1994). Depois dos anos 50's, a LTA tornou-se endêmica na região sul do estado e sua transmissão deixou de ser influenciada pelos fatores ambientais do 
desmatamento, passando a ser dependente principalmente da adaptação de insetos vetores no ambiente humano e de animais de criação (CAMARGO-NEVES et al., 2002).

L. (V.) braziliensis é o principal agente etiológico da LTA no estado de SP, a qual é transmitida por 5 espécies de flebotomíneos: Nyssomyia intermedia, Nyssomyia neivai, Nyssomyia whitmani, Migonemyia migonei e Pintomyia pessoai (MARCONDES, 1996; CAMARGO-NEVES et al., 2002; ANDRADE-FILHO et al., 2007). L. (L.) amazonensis também tem sido descrita no nordeste de São Paulo (MEDEIROS et al., 2008), porém o único vetor reconhecido para esta espécie é Bichromomyia flaviscutellata, o qual tem sido reportado apenas na costa sul do estado de SP (GOMES et al., 1990).

\subsubsection{DISTRIBUIÇÃO DOS FLEBOTOMÍNEOS NO ESTADO DE SÃO PAULO}

Em 2010, Shimabukuro et al. reuniram todos os dados de distribuição de flebotomíneos do estado de SP entre os anos 1943 e 2009 (publicações e registros da SUCEN) e foram contrastados com os casos de LTA notificados. Descreveu-se a presença de pelo menos uma das 5 espécies relacionadas à transmissão da LTA em 183 (28,4\%) dos 645 municípios do estado. Para os demais municípios, não havia informação disponível, e não existem estudos públicos que reportem a presença de flebotomíneos; a maioria destes municípios se encontra no centro e norte do estado (SHIMABUKURO et al., 2010).

Nyssomyia intermedia e Nyssomyia neivai foram as espécies descritas com maior frequência, principalmente na região sul do estado onde existe maior prevalência de LTA (Figura 9).

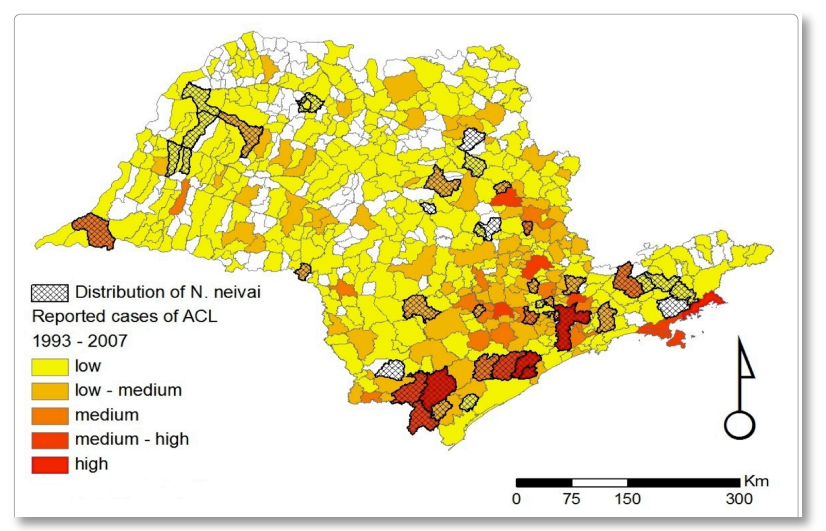

Figura 9. Distribuição de Nyssomyia neivai em relação aos casos reportados de Leishmaniose Tegumentar Americana no Estado de São Paulo. Representação esquemática dos municípios do estado de São Paulo. Em tonalidades de amarelo até vermelho (baixa até alta respectivamente) mostram a incidência de Leishmaniose Tegumentar Americana. Municípios riscados revelam a presença de Nyssomyia neivai. Fonte: SHIMABUKURO et al., 2010. 
A forma sistêmica da infecção por leishmania - Leishmaniose Visceral (LV) - vem ocorrendo no estado de São Paulo em municípios situados na região oeste. A espécie de flebotomíneo envolvida na transmissão é Lutzomyia longipalpis, a qual foi registrada pela primeira vez no município de Araçatuba, em 1997 (CAMARGO-NEVES et al., 1999). Camargo-Neves et al. realizaram, em 2003, revisão epidemiológica de LV no estado de SP, verificando a expansão da doença e o aumento do número de casos em todos os municípios onde a doença havia sido detectada (Figura 10) (CAMARGO-NEVES, et al, 2003).

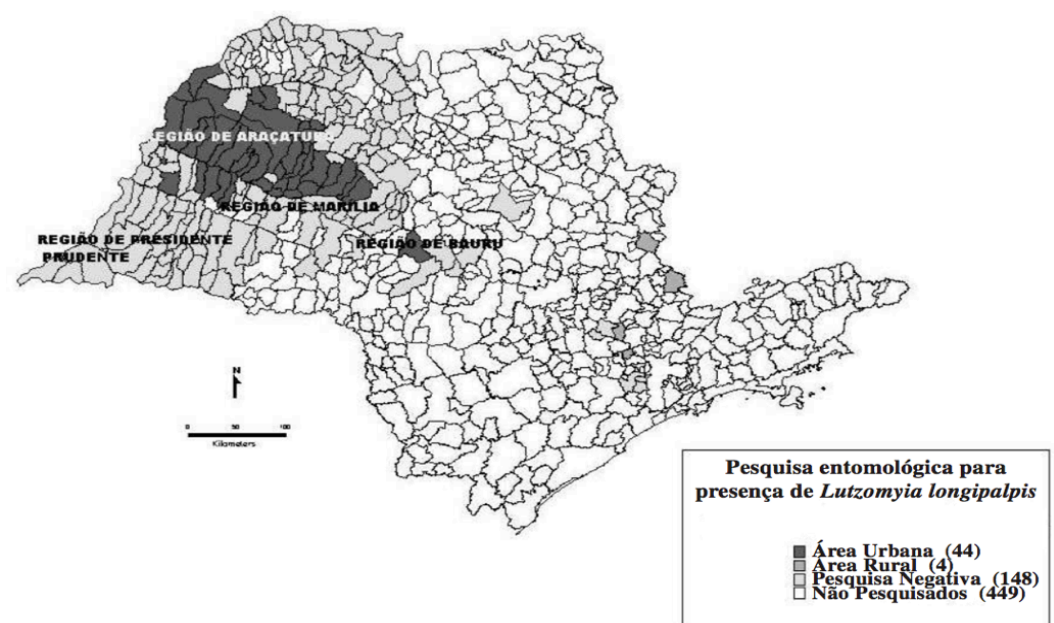

Figura 10. Distribuição de Lutzomyia longipalpis no Estado de São Paulo. Representação esquemática dos municípios do estado de São Paulo. Em tonalidades de cinza mostra-se a pesquisa entomológica positiva, negativa ou não pesquisa de Lutzomyia longipalpis. Fonte: CAMARGO-NEVES et al, 2003.

\subsubsection{PROTEÍNAS SALIVARES (SIALOTRANSCRIPTOMA) DE LUTZOMYIA LONGIPALPIS}

Em 2001, constatou-se que soros de pacientes com PF apresentavam maiores títulos de anticorpos contra Maxadilan - proteína salivar de Lu. longipalpis - comparados aos indivíduos saudáveis moradores da mesma região endêmica (ROSELINO et al., 2001).

Considerando a reação cruzada entre anticorpos $\operatorname{IgE}$ e $\operatorname{IgG}_{4}$ contra o extrato salivar de $L u$. longipalpis, Qian et al. realizaram testes adicionais utilizando três proteínas altamente imunogênicas do sialoma de Lu. Longipalpis: LJM11, LJM17 e LJL143 (QIAN et al., 2012; VALENZUELA et al., 2004). Curiosamente, Maxadilan, a proteína mais imunogênica do extrato salivar, não foi utilizada nesses testes. Esses experimentos evidenciaram que os anticorpos monoclonais $\mathrm{IgG}_{4}$ anti-Dsg1, isolados de pacientes com PF, reagiram de maneira cruzada aos antígenos Dsg1 e LJM11. Além disso, camundongos imunizados contra LJM11, mas não contra 
LJM17 e LJL143, desenvolveram intensa resposta humoral à Dsg1 humana. Todas essas evidências sugerem fortemente a existência de um fenômeno de "antigenic mimecry" entre LJM11 e Dsg1 (Figura 11) (QIAN et al., 2012).

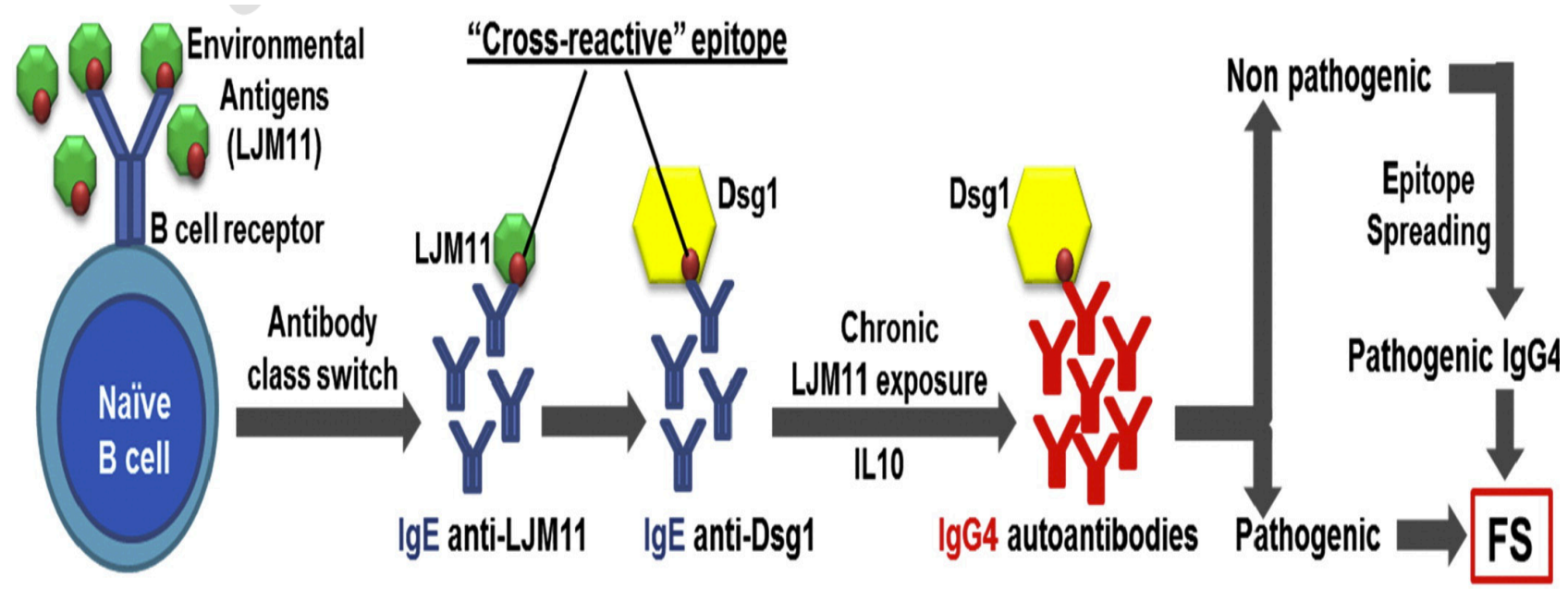

Figura 11. Hipótese sobre a reatividade cruzada entre antígenos ambientais e a etiopatogênese do pênfigo foliáceo endêmico. A exposição ao estímulo ambiental (nesse caso a proteína salivar LJM11) levaria inicialmente a uma resposta por hipersensibilidade à produção de anticorpo IgE anti-LJM11 os quais levariam um reação cruzada por mimetismo antigênico à produção de anticorpos IgE anti-Desmogleína 1. A exposição crônica levaria a uma estimulação de IL-10 e consequentemente a uma troca do perfil de anticorpos para $\operatorname{IgG}_{4}$ (patogênicos) contra Desmogleína 1. Fonte: QIAN et al., 2016.

\subsection{CULICÍDEOS}

Assim como os flebotomíneos, esses insetos pertencem à ordem Diptera, família Culicidae. O gênero Aedes é responsável pela transmissão da Dengue, sendo incriminadas várias espécies do subgênero Stegomyia (Aedes aegypti, Aedes albopcitus e Aedes polynesiensis), nas quais o vírus foi encontrado in natura (BRAGA et al., 2007). A espécie A. aegypti tem distribuição mundial encontrando-se em geral entre as latitudes $35^{\circ}$ Norte e $35^{\circ}$ Sul, que correspondem à isoterma de inverno de $10^{\circ} \mathrm{C}$ (GUZMAN; HARRIS, 2015). É um mosquito adaptado ao ambiente urbano e utiliza os recipientes mais frequentes no domicílio ou peridomicílio, tanques de armazenamento de água e vasilhames temporários como potes, barris, pneumáticos usados, etc., para o desenvolvimento de sua fase larvária (BRAGA et al., 2007; WHO, 2009).

Nas Américas, embora amplamente disseminado, até o momento, não há evidências de que Aedes albopictus seja eficiente transmissor da dengue. No entanto, A. aegypti, responsável pela transmissão dessa doença desde a década 50 no Brasil, apresentou sucessivos registros de reintrodução no nosso país, estabelecendo-se definitivamente ao final do século XX (TEIXEIRA et 
al., 2009). Atualmente, essas espécies estão presentes em 3.592 (A. aegypti) e 1.533 (Aedes albopictus) munícipios brasileiros (HONÓRIO, LOURENÇO-DE OLIVEIRA, 2001). No estado de São Paulo, a infestação teve início na década dos anos 80. Em 1995, foi registrada a presença desses vetores em 626 municípios, quando 415 estavam infestados por A. aegypti (GLASSER et al., 2000).

A ocorrência de sucessivas epidemias de dengue em todo o mundo e no Brasil, em particular, vem sendo objeto de inquietação por parte de técnicos, pesquisadores e da sociedade em geral, com aumento da morbidade e letalidade (WHO, 2009).

$\mathrm{Na}$ literatura médica, não existem registros que relacionem a picada de $A$. aegypti com a etiopatogênese do PF. Porém, Dipteros, incluindo Simuliidae e Psychodidae, possuem certas famílias de proteínas salivares em comum, especificamente a família D7/odorant-binding protein, que auxiliam nos processos de vasoconstrição, antiplaquetário e inflamatório (JABLONKA, 2019; VALENZUELA et al., 2002). Do mesmo modo, uma proteína salivar imunogênica, conhecida como antígeno $30 \mathrm{kDa} /$ Aegyptin presente no A. Aegypti, com função antiplaquetária, também foi descrita no sialotranscriptoma de $S$. nigrimanum, demonstrando a única família de proteínas salivares que descreve origem comum entre Blackflies e Mosquitae (JABLONKA, 2019; RIBEIRO et al., 2010; GRIMALDI, ENGEL, 2005).

\subsection{INSETOS HEMATÓFAGOS E A ENDEMICIDADE DO PÊNFIGO FOLIÁCEO ENDÊMICO NO NORDESTE DO ESTADO DE SÃO PAULO}

Os pênfigos têm sido extensivamente estudados ao nível molecular, em especial suas características genéticas e imunológicas, porém, a etiopatogênese ainda se encontra incompreendida. O papel dos fatores ambientais é crucial no estudo dos pênfigos, pois na forma endêmica do PF em alguns países, ainda é desconhecido, suscitando vasto campo para pesquisa.

Embora S. nigrimanum seja o Simulídeo antropofílico mais citado na literatura médica em relação à etiopatogênese do PF (AOKI et al., 2004; DIAZ et al., 1989; EATON et al., 1998, LOMBARDI et al., 1992), outras espécies de Simulídeos antropofílicos estão distribuídas nas regiões onde existem registros de pênfigos, como Simulium pertinax e Simulium incrustatum (EATON et al., 1998). Porém, a distribuição destas duas últimas espécies não tem sido descrita na região nordeste do Estado de São Paulo.

Lu. longipalpis é sem dúvida o flebotomíneo que tem sido mais estudado no desenvolvimento do PF. Os componentes anticoagulantes, antiplaquetários, anestésicos e 
vasodilatores da saliva destes insetos, além da ação imunomoduladora, têm sido alvo de amplo estudo, demonstrando-se nos últimos anos estreita relação da proteína salivar LJM11 com a etiopatogênese do PF (QIAN et al., 2016). Por outro lado, a proteína Maxadilan, descrita inicialmente em Lu. longipalpis e posteriormente descrita em N. neivai (AIRES et al., 2017), também tem sido relacionada em pacientes com PF.

Apesar do A. aegypti não ter sido alvo de estudo em relação ao desencadeamento do PF, no estado de São Paulo existe uma relação epidemiológica importante entre a presença de A. aegypti e sua expansão geográfica ao longo da região nordeste do estado (SUCEN, 2015 ). No Estado de São Paulo registrou-se, em 2007, a mais elevada incidência de dengue desde o início da transmissão no Estado, sendo de 219,8/100 mil habitantes (FERREIRA et al., 2009), o que acompanha o aumento nos casos de PF registrados no Hospital das Clínicas-FMRP-USP nas últimas décadas (CELERE et al., 2017; GONÇALVES et al., 2011)

A importância da identificação de um provável mimetismo antigênico molecular entre peptídeos salivares de insetos hematófagos, amplamente distribuídos em regiões endêmicas para $\mathrm{PF}$, e componentes epidérmicos humanos, e sua possível participação na etiopatogênese dessa doença leva ao objetivo principal deste estudo. 


\section{OBJETIVOS}

\subsection{OBJETIVO GERAL}

Verificar a participação das proteínas salivares de insetos hematófagos na etiopatogênese do PF em amostragem da região nordeste do estado de São Paulo (NESP), Brasil.

\subsection{OBJETIVOS ESPECÍFICOS}

3.2.1 Mapear a distribuição das principais espécies antropofílicas de simulídeos e flebotomíneos em relação aos casos de PF descritos na região NESP: relação epidemiológica (presença de inseto/doença) (manuscrito 1 - publicado).

3.2.2 Quantificar a resposta imune humoral IgG e IgE em amostras séricas de pacientes com PF e controles contra antígenos salivares dos insetos hematófagos distribuídos na região NESP: A. aegypti, N. neivai e S. nigrimanum (ensaio ELISA in-house) (manuscrito 2 - submetido).

3.2.3 Identificar quais frações proteicas salivares dos insetos $N$. neivai e S. nigrimanum são reconhecidas pelos anticorpos dos pacientes com PF e controles (IB) (manuscrito 3 - em submissão).

3.2.4 Quantificar a reposta imune humoral IgG em amostras séricas de pacientes com PF e controles contra as duas principais proteínas salivares de Lu. longipalpis relacionadas à etiopatogênese do PF na literatura médica: Maxadilan e LJM11 (ensaio ELISA in-house) (manuscrito 4 - submetido).

3.2.5 Descrever o sialotranscriptoma de N. neivai (manuscrito 5 - em submetido). 
Resultados 


\section{RESULTADOS}

Os resultados dessa Tese de Doutorado serão apresentados em formato de manuscrito, sendo que o primeiro deles já foi publicado em jornal internacional no ano 2017. De maneira complementar, outros resultados obtidos, porém ainda não incorporados nos manuscritos supracitados submetidos para publicação, serão apresentados em formato regular de acordo com estrutura da tese e serão abordados de forma global na seção de discussão.

\subsection{ARTIGOS PUBLICADOS.}

5.1.1 Insights into the epidemiological link between biting flies and pemphigus foliaceus in southeastern Brazil. Jornal: ACTA TROPICA. Fator de impacto: 2,629. Formato: Original article

Insights into the epidemiological link between biting flies and pemphigus foliaceus in southeastern Brazil, Acta Tropica, 2017;176:455-462

S. Vernal; M. Pepinelli; C. Casanova; T. Goulart; O. Kim; N. De Paula; M. Pinto; A. Sá-Nunes; A.M. Roselino 


\title{
Insights into the epidemiological link between biting flies and pemphigus foliaceus in southeastern Brazil
}

\author{
Sebastian Vernal ${ }^{\mathrm{a}}$, Mateus Pepinelli ${ }^{\mathrm{b}, \mathrm{c}}$, Claudio Casanova ${ }^{\mathrm{d}}$, Thais M. Goulart ${ }^{\mathrm{e}}$, Olivia Kim ${ }^{\mathrm{a}}$, \\ Natalia A. De Paula ${ }^{a}$, Mara C. Pinto ${ }^{f}$, Anderson Sá-Nunes ${ }^{g}$, Ana Maria Roselino ${ }^{a, *}$ \\ a Division of Dermatology, Department of Clinical Medicine, Ribeirão Preto Medical School, University of São Paulo, Ribeirão Preto, São Paulo, Brazil \\ b Department of Natural History, Royal Ontario Museum, Toronto, Ontario, Canada \\ ${ }^{\mathrm{c}}$ Department of Ecology and Evolutionary Biology, University of Toronto, Toronto, Ontario, Canada \\ d Superintendence for Endemic Disease Control, Health Secretariat of São Paulo State, Mogi-Guaçu, São Paulo, Brazil \\ e Institute of Biology, Department of Animal Biology, State University of Campinas, Campinas, São Paulo, Brazil \\ ${ }^{\mathrm{f}}$ Department of Parasitology, São Paulo State University Julio de Mesquita Filho, Araraquara, São Paulo, Brazil \\ ${ }^{g}$ Department of Immunology, Institute of Biomedical Sciences, University of São Paulo, São Paulo, Brazil
}

\section{A R T I C L E I N F O}

\section{Keywords:}

Pemphigus foliaceus

Black flies

Sandflies

Simuliidae

Phlebotomine

\begin{abstract}
A B S T R A C T
Background: Black fly and sandfly bites are related to the endemicity of pemphigus foliaceus (PF); however, an immune reaction against the salivary proteins from these flies still requires confirmation in the case of $\mathrm{PF}$ patients living in southeastern Brazil.

Purpose: To georeference the distribution of Simuliidae (Diptera: Simuliidae) and Phlebotominae (Diptera: Psychodidae) and of PF cases in the northeastern region of São Paulo State, and to assess the humoral immune response against salivary gland extracts (SGEs) from biting flies in PF patients, relatives, and neighbours.

Methods: PF patients' medical information recorded between 1965 and 2014 were obtained from the database of the University Hospital. Data on the distribution of fly species were collected from scientific reports and epidemiological databases. Spatial maps relating the distribution of biting flies with PF cases were plotted. Serum IgG antibodies against the SGEs from Simulium nigrimanum, Nyssomyia neivai, and Aedes aegypti (as control) were determined by ELISA.

Results: Two hundred and eighty-five PF cases were distributed in 60 municipalities with a prevalence of 57.5 per million inhabitants, revealing well-defined geographical clusters. $S$. nigrimanum and $N$. neivai specimens were registered in eight (13.3\%) and 26 (43.3\%) of these municipalities, respectively. PF patients, and their relatives presented higher levels of IgG against the SGEs of $S$. nigrimanum and $N$. neivai $(P<0.001$ for both), but not against the SGE from $A$. aegypti $(P=0.115$ and $P=0.552$, respectively), as compared to controls. IgG against the SGEs from $S$. nigrimanum and $N$. neivai but not against the SGE from A. aegypti correlated with levels of antiDesmoglein 1 in PF patients $(r=0.3848, P=0.039$; and $r=0.416, P=0.022$, respectively).

Conclusion: An epidemiological link between biting flies and PF in southeastern Brazil is proposed, implying a possible role of the salivary proteins from these flies in PF etiopathogenesis.
\end{abstract}

\section{Introduction}

Pemphigus foliaceus (PF) is an autoimmune bullous disease caused by autoantibodies against desmoglein (DSG) 1. It is subdivided into classic sporadic worldwide Cazenave's pemphigus and endemic pemphigus (known as Fogo Selvagem in Brazil). Although the pathogenesis of PF remains unclear, genetic and environmental factors have been implicated in the susceptibility to this disease (Abréu-Vélez et al., 2010;
Brochado et al., 2016).

Historically, PF cases have been recorded in rural areas of Brazil and other South American countries such as Colombia, Peru, Paraguay, and Venezuela (Abréu-Vélez et al., 2010; Diaz et al., 1989). That insect bites might be associated with PF has been pointed out since 1940 (Vieira, 1940), when an epidemiological link between Simulium nigrimanum (Macquart, 1838) and the endemicity of PF was hypothesized in São Paulo State, southeastern Brazil (Vieira, 1940). PF remains endemic in

Abbreviations: ATL, American Tegumentary Leishmaniasis; DSG, Desmoglein; NRSP, northeastern region of São Paulo State; SGE, salivary gland extract; PF, Pemphigus Foliaceus; VL, Visceral Leishmaniasis

* Corresponding author at: Ribeirão Preto Medical School, University of São Paulo. Av. Bandeirantes 3900, Monte Alegre, Ribeirão Preto, São Paulo, Brazil.

E-mail address: amfrosel@fmrp.usp.br (A.M. Roselino). 
the northeastern region of São Paulo State (Abréu-Vélez et al., 2010; Diaz et al., 1989; Roselino and Almeida, 1995). S. nigrimanum bites have been considered a risk factor for the development of $P F$ in an Amerindian reserve in Mato Grosso do Sul State, Brazil (Aoki et al., 2004; Hans-Filho et al., 1996; Eaton et al., 1998; Lombardi et al., 1992). Two other widespread voracious black fly species-Simulium pertinax (Kollar, 1882) and Simulium incrustatum (Lutz, 1910)-have also been linked to the endemicity of PF in this same reserve (Eaton et al., 1998).

The relation between $S$. nigrimanum and other hematophagous insects with PF has been not explored enough in southeastern Brazil. Higher levels of serum IgG against maxadilan - a highly immunogenic salivary protein described in Lutzomyia longipalpis (Lutz and Neiva, 1912), a vector of visceral leishmaniasis (VL) (Lerner et al., 1991)have been determined in PF patients as compared to controls living in a southeastern Brazilian region where PF is endemic (Roselino et al., 2001). There is also evidence that LJM11, another highly immunogenic protein from $\mathrm{Lu}$. longipalpis, cross-reacts with antibodies against DSG1 (Qian et al., 2012). Zaraa et al. (Zaraa et al., 2012) have also reported the recognition of the salivary protein from Phlebotomus papatasi (Scopoli, 1786) by patients' sera in a Tunisian region where $\mathrm{PF}$ is endemic.

Nyssomyia intermedia (Lutz \& Neiva, 1912) and Nyssomyia neivai (Pinto, 1926) (= syn. Lutzomyia intermedia) are the main vectors of $L$. $(V$.$) braziliensis in São Paulo State. Moreover, N. neivai has been iden-$ tified in research collections done systematically in several municipalities of the northeastern region of São Paulo State (Andrade Filho et al., 2007). $\mathrm{Lu}$. longipalpis is mainly distributed in the western region of São Paulo State, but it has not been related to VL in the northeastern region of this state (Casanova et al., 2015).

Another important group of biting insect -Culicidae- has never been associated with PF; however, 23 (76\%) out of $30 \mathrm{PF}$ patients have reported mosquito bites in a Brazilian Amerindian reserve (Lombardi et al., 1992). Mosquitoes are vectors of various pathogens, including the Dengue and the Zika viruses, and their populations have been also reported in areas of São Paulo State where PF is endemic (Glasser and de Castro Gomes, 2000).

Considering these previous studies, the relation between the distribution of black flies and sandflies with the endemicity of PF in southeastern Brazil requires confirmation. Furthermore, assessment of PF patients exposed to bites of these flies is mandatory to establish an epidemiological link. The present study aims (i) to compare the spatial distribution of black flies (Diptera: Simuliidae) and Phlebotominae sandflies (Diptera: Psychodidae) with PF cases georeferenced in the northeastern region of São Paulo State; and (ii) to demonstrate that serum samples from PF patients recognize salivary gland extracts (SGEs) from S. nigrimanum (Simuliidae), N. neivai (Phlebotominae), and Aedes aegypti (Linnaeus, 1762) (Culicidae) populations from the studied region.

\section{Materials and methods}

\subsection{Mapping and spatial distribution}

\subsubsection{Type of study}

This is an observational study with a retrospective cohort analysis

\subsubsection{PF cases}

Medical records of PF cases were collected from the database of the University Hospital of the Ribeirão Preto Medical School, University of São Paulo, Brazil. Records concerned patients who resided in the northeastern region of São Paulo State (hereafter referred as NRSP) at the onset of PF symptoms between 1965 and 2014. The clinical diagnosis of PF was confirmed by acantholytic bullae on the histopathological examination, positive IgG fluorescence around keratinocytes in skin samples, and presence of serum autoantibodies against DSG1 as revealed by ELISA (MBL, Nagoya, Japan).

\subsubsection{Study area}

NRSP, southeastern Brazil, has a tropical climate and is located between $19^{\circ} 52^{\prime}$ and $22^{\circ} 51^{\prime} \mathrm{S}$ and $46^{\circ} 16^{\prime}$ and $49^{\circ} 20^{\prime} \mathrm{W}$. The region comprises 125 municipalities that cover an area of $51,661 \mathrm{~km}^{2}$. This region represents about $21 \%$ of the total area of the state and was inhabited by $5,156,660$ people in 2016 (IBGE, 2017).

\subsubsection{Data on black flies}

Reports of $S$. nigrimanum collections in NRSP have been registered since the beginning of the last century (Vieira, 1940). Most data were obtained from Dr Mateus Pepinelli doctoral thesis, in which he reports collecting specimens from 151 streams and rivers across São Paulo State, of which 26 were situated in 25 NRSP municipalities. Collections were accomplished between 2002 and 2005 (Pepinelli, 2008).

\subsubsection{Data on sandflies}

The distribution of sandflies was obtained from epidemiological data deposited at the database of the Health Secretariat of São Paulo State since 1940, obtained mainly via the VL and American tegumentary leishmaniasis (ATL) surveillance programs. Entomological collections were performed in locations with known or suspected human cases of ATL and in municipalities with suspected or confirmed cases of human and canine VL; a minimum of four dwellings were sampled (Casanova et al., 2015; Casanova et al., 2014; Secretary of Health of São Paulo State, 2011; Secretary of Health of São Paulo State, 2008).

\subsubsection{Spatial maps}

The scale for map construction was 1:3,266,000 kilometres (0-130.7 latitude/longitude projection). Cases were plotted against the number of patients in each municipality of NRSP. Black fly and sandfly records were also plotted per municipality.

\subsubsection{Nomenclature}

Nomenclature of insect species follows Galati and Adler \& Crosskey's guidelines (Adler and Crosskey, 2015; Galati, 2003). Abbreviation of generic names for sandflies follows Marcondes' guidelines (Marcondes, 2007).

\subsection{Assessment of exposure to bites}

\subsubsection{Type of study}

This is a transversal study

\subsubsection{Samples of insects}

Given their pest status and wide distribution, $S$. nigrimanum and $N$. neivai were included as the most representative simuliid and phlebotomine, respectively, of the target region. A. aegypti-another biting fly that is widely distributed in NRSP (Glasser and de Castro Gomes, 2000) but which has not been related to $\mathrm{PF}$-was included as a control.

2.2.2.1. Simulium nigrimanum. Adult females were collected in Ribeirão Corrente river, in the municipality of Jardinópolis, NRSP $\left(20^{\circ} 30^{\prime} 30.04^{\prime \prime} S\right.$, $47^{\circ} 33^{\prime} 04.34^{\prime \prime}$ ) during oviposition, while flying, or while biting humans. Aquatic life stages were collected for additional identification, following Hamada \& Pepinelli methods (Hamada and Pepinelli, 2004).

2.2.2.2. Nyssomyia neivai. Adult female samples were obtained from a laboratorial colony supervised by Dr Mara Pinto, State University of São Paulo, Araraquara, Brazil.

2.2.2.3. Aedes aegypti. Adult female samples were obtained from a laboratorial colony supervised by Dr Anderson Sá-Nunes, Institute of Biomedical Sciences, University of São Paulo, São Paulo, Brazil. 


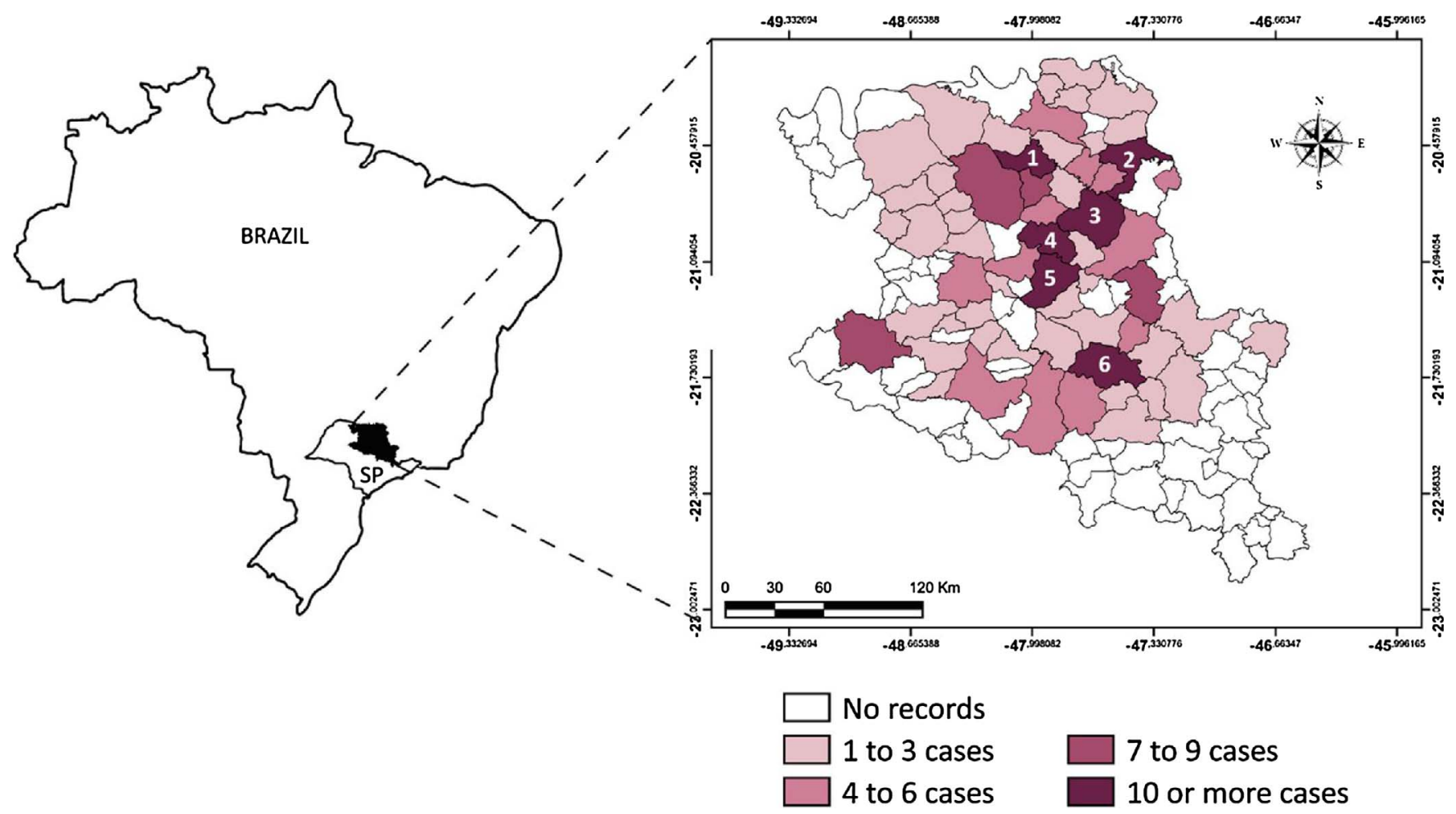

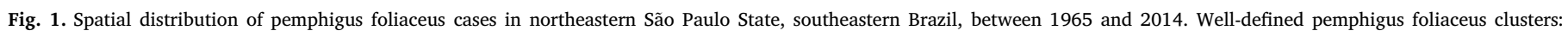

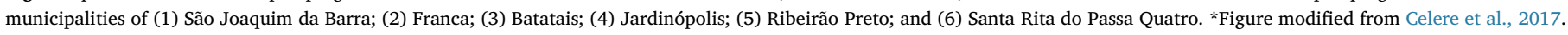

\subsubsection{Salivary gland extracts (SGEs)}

Salivary glands were dissected and stored in phosphate-buffered saline (PBS, $\mathrm{pH}$ 7.4). Salivary protein extracts were properly characterized in SDS gel (Supplementary Fig. 1S). Immediately before use, the SGEs were disrupted by ultrasonication and centrifuged at 14,000 $g$; the resulting supernatant -SGE- was used in this study (Bizzarro et al., 2013; Souza et al., 2010).

\subsubsection{In-house ELISA}

To assess exposure to bites, an in-house ELISA assay was standardized with the SGE from each species of insect. Briefly, $300 \mathrm{ng}$ of SGE diluted in PBS was incubated in 96-well microplates (Corning, SigmaAldrich, St. Louis, USA) overnight and blocked with PBS/Tween/ $0.005 \% / B S A 1 \%$ for an hour. After three washings, the patients' sera (1:100, in duplicate) were monitored with secondary antibody 1:10,000 (anti-human IgG, Abcam, Cambridge, USA). Then, the wells were washed four times, and $100 \mu \mathrm{L}$ of chromogenic substrate $\left(3,3^{\prime}, 5,5^{\prime}\right.$ Tetramethylbenzidine-TMB) was added. After 15-min incubation at room temperature (in the dark), $50 \mu \mathrm{L}$ of stop solution $\left(0.2 \mathrm{M} \mathrm{H}_{2} \mathrm{SO}_{4}\right.$, was added. The Optical Density (OD) values were determined with an ELISA plate reader (Biochrom Asys Expert Plus Microplate Reader, Cambourne, Cambridge, UK) fitted with a 450-nm absorbance filter. Inhouse ELISA was performed by a blinded technician, in duplicate, on the same day; the same reagents were used to avoid plate variability. The experiments were performed twice. In-house ELISA was not considered as a diagnostic tool for PF. Hence, instead of positive/negative results being presented, in-house ELISA was used only as a comparative tool to assess the humoral response to SGEs. In-house ELISA was validated by using serum samples from female rabbits before and after immunization with each SGEs (Supplementary Material and Methods).

\subsubsection{Serum samples}

Thirty serum samples from PF patients were compiled randomly from the Pemphigus Bank of the Laboratory of Dermatology at the University Hospital of the Ribeirão Preto Medical School, University of
São Paulo, Brazil. All the patients presented active clinical disease with the presence of Nikolsky's sign at the moment serum was collected. The control groups consisted of 30 healthy relatives of PF patients and 30 healthy neighbours of PF patients' living in the same studied region and without any clinical manifestation of PF. They comprised first-degree family members and accompanying neighbour on the occasion of the outpatient appointment.

\subsubsection{Statistical analysis}

Parametric model assumptions were assessed by means of a normal plot. Demographic and clinical data from patients and controls were compared by non-parametric tests as appropriate. Kruskall-Wallis followed by Dunn's test was employed to compare ELISA OD values amongst the groups. The Spearman's test was used to correlate the levels of antibodies against SGEs and anti-DSG1 as well as the levels of antibodies and time of disease in the PF group. Significance was set at $\propto=5 \%$. GraphPad Prism 7 was used for the statistical analysis (GraphPad software Inc., La Jolla, CA, USA).

\subsubsection{Ethics}

This study was approved by the local Human Research Ethics Committee (\#866.027/2014), in accordance with the ethical standards of the Helsinki Declaration of the World Medical Association; it was also approved by the Animal Research Ethics Committee (\#78/2015).

\section{Results}

\subsection{Georeferencing analysis}

The georeferenced maps illustrate the distribution of $285 \mathrm{PF}$ cases in 60 (48\%) out of 125 municipalities whose prevalence comprised 57.5/ $1,000,000$ inhabitants in NRSP. Six municipalities concentrated ten or more PF cases (Fig. 1).

Concerning the distribution of anthropophilic Simuliidae species, the compiled data refer to specimens collected in 25 (20\%) out of 125 


\section{Distribution of the main Black flies in northeastern Sao Paulo State, southeastern Brazil}

\section{(A) Simulium nigrimanum distribution}

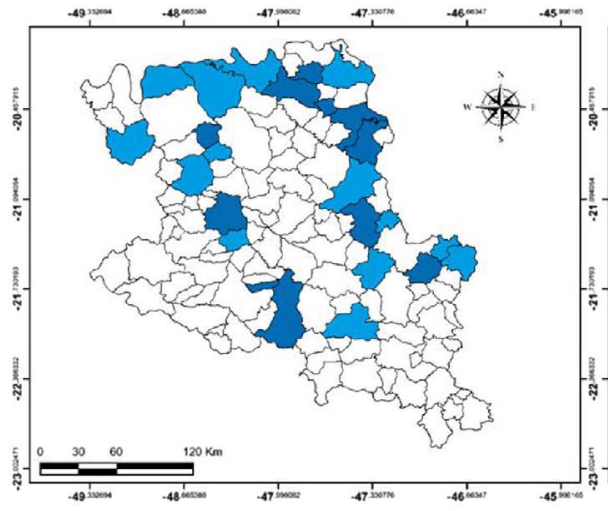

(B) Simulium pertinax distribution

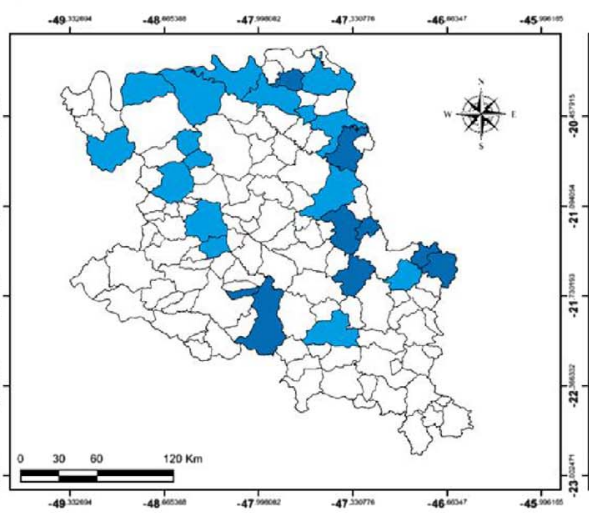

(C) Simulium incrustatum distribution

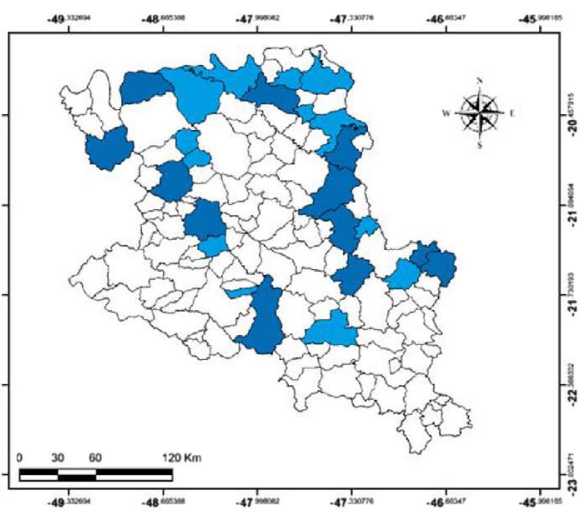

No records

Not founded

Positive collection

\section{Distribution of the main Sandflies in northeastern Sao Paulo State, southeastern Brazil}

(D) Nyssomyia neivai distribution

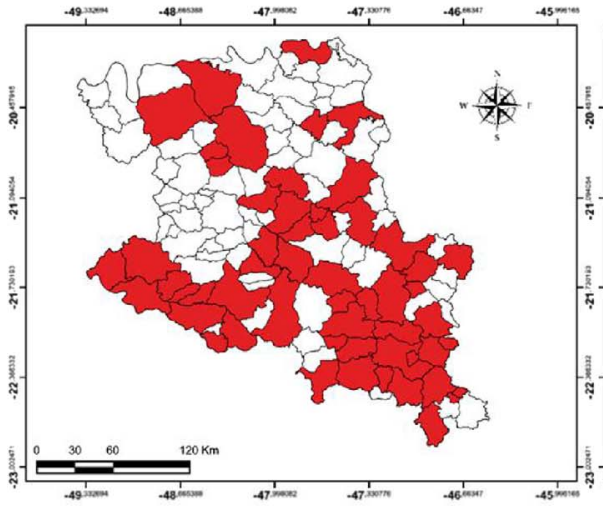

(G) Pintomyia pessoai distribution
(E) Nyssomyia whitmani distribution

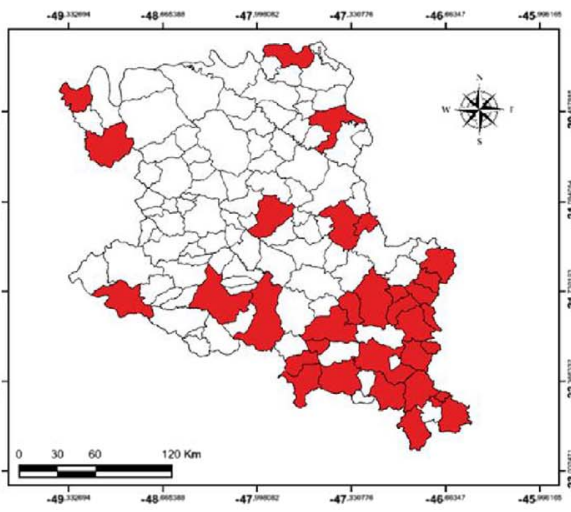

(H) Pintomyia fischeri distribution
(F) Lutzomyia longipalpis distribution

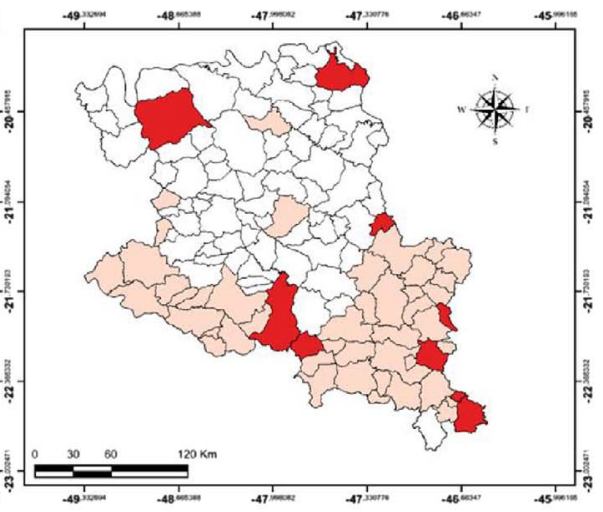

(I) Migonemyia migonei distribution

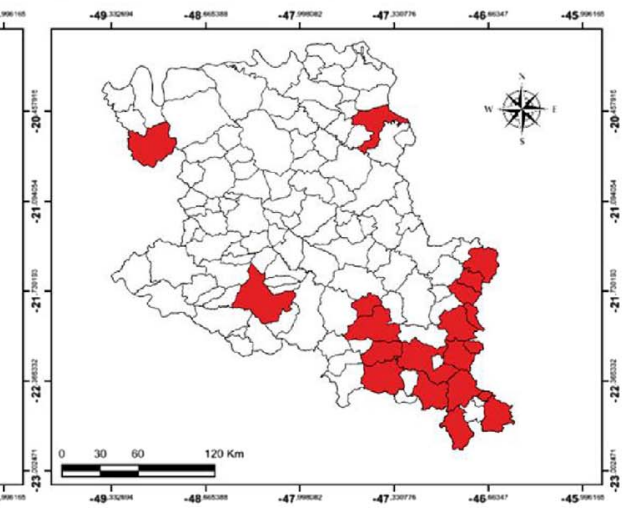

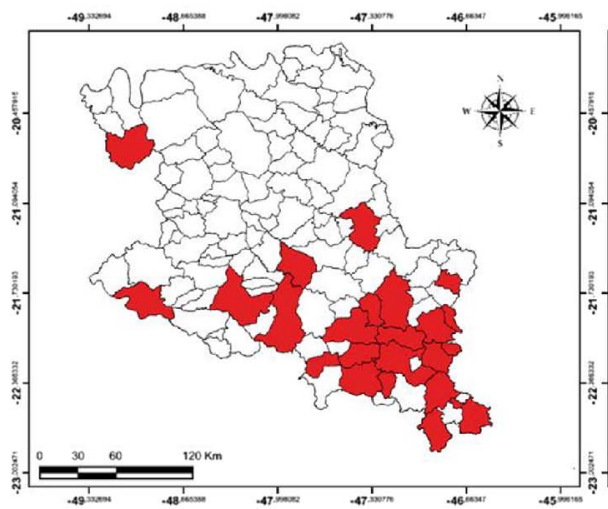

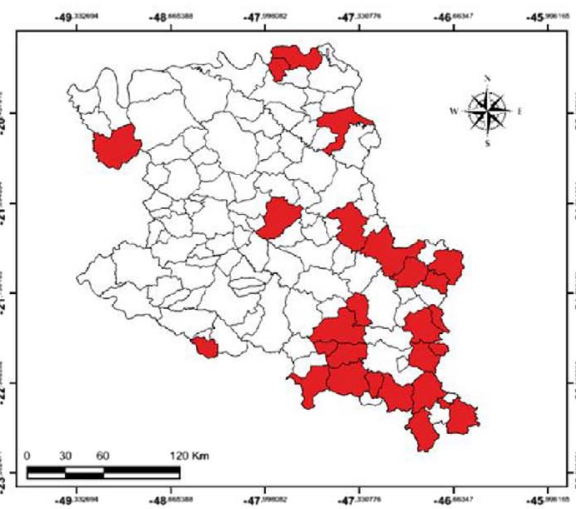

$\square$ No records $\quad \square$ Not founded $\quad \square$ Positive collection

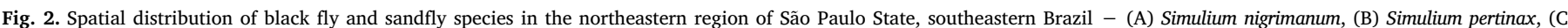
Simulium incrustatum, (D) Nyssomyia neivai, (E) Nyssomyia whitmani, (F) Lutzomyia longipalpis, (G) Pintomyia pessoai, (H) Pintomyia fischeri, and (I) Mygonemyia migonei.

municipalities. Fig. 2A-C shows that Simuliidae was distributed around the main PF focus. S. nigrimanum was recorded in $11(44 \%)$ out of 25 municipalities (Fig. 2A), including eight (72.7\%) municipalities where PF cases were registered. One of these municipalities corresponded to a well-defined PF geographical cluster (municipality of Franca, number 2,
Fig. 1). S. pertinax was distributed in nine (36\%) out of 25 municipalities; PF cases occurred in five (55.5\%) of them (Fig. 2B). S. incrustatum was detected in 12 (48\%) out of 25 municipalities; PF cases were registered in eight (66.6\%) of them (Fig. 2C). It is noteworthy that $S$. nigrimanum, $S$. pertinax and $S$. incrustatum have been found inhabiting 
streams of the same municipality area in three cases, and that PF was reported in two of these municipalities (Cajuru and São Carlos municipalities).

Regarding the distribution of sandflies (Fig. 2D-I), the compiled data refer to specimens collected in $76(60.8 \%)$ out of 125 municipalities. $N$. neivai was recorded in 55 (44\%) municipalities (Fig. 2D). PF cases occurred in $26(47.2 \%)$ out of these 55 municipalities. The presence of $N$. neivai in four out of six well-defined PF clusters is worthy of note. Comparison of the spatial distribution of $N$. neivai with the spatial distribution of other studied sandflies revealed that this species was the most widely distributed in NRSP, followed by Nyssomyia whitmani (Antunes \& Coutinho, 1939) (Fig. 2E), reported in 33 (26.4\%) out of 125 municipalities, 13 (39.4\%) of which had reported PF cases.

$\mathrm{Lu}$. longipalpis was investigated in $44(35.2 \%)$ out of 125 municipalities. There were positive records in nine (20.5\%) out of 44 municipalities, which represented less than $8 \%$ of the total number of municipalities in the region. The distribution of $L u$. longipalpis did not match the occurrence of any well-defined PF cluster (Fig. 2F).

We also plotted the distribution of other sandfly species-Pintomyia pessoai (Coutinho \& Barreto, 1940), Pintomyia fischeri (Pinto, 1926), and Migonemyia migonei (França, 1920) (Fig. 2G-I).

\subsection{Immunological study}

We tested serum samples obtained from $30 \mathrm{PF}$ patients (median age $=47$ years, 18 females), $30 \mathrm{PF}$ patients' healthy first-degree relatives (median age $=46$ years, 23 females), and $30 \mathrm{PF}$ patients' healthy neighbours (median age $=55$ years, 12 females) as controls living in the same area where PF is endemic. Table 1 summarizes the clinical and the laboratorial data (for more details please check Supplementary Table $1 \mathrm{~S}$ and Supplementary Table $2 S$ ). No significant differences were found among groups related to gender $(P=0.117)$. There were no significant differences between PF patients as compared to relatives and neighbours in terms of gender, but healthy neighbours were older than healthy relatives $(P=0.029)$. The median time of $\mathrm{PF}$ evolution was nine years (p25th 2 years, p75th 18 years), and most of the patients $(83.3 \%)$ were being treated for PF at the moment serum was collected. The PF patients that had not started immunosuppressive treatment or who had been without treatment for at least 60 days at the moment serum was collected tended to have higher values of anti-DSG1 as compared to PF patients under treatment $(P=0.065)$ (data not shown).

Fig. 3 shows the detection of IgG against the SGE from each insect. There were no statistical differences amongst the PF patients, their

Table 1

Demographic and clinical data from pemphigus foliaceus (PF) patients, PF patients' healthy relatives, and PF patients' healthy neighbours.

\begin{tabular}{|c|c|c|c|c|c|}
\hline & & PF patients & $\begin{array}{l}\text { Healthy } \\
\text { relatives }\end{array}$ & $\begin{array}{l}\text { Healthy } \\
\text { neighbours }\end{array}$ & $P$-value \\
\hline \multirow[t]{2}{*}{ Gender } & Female & $18(60 \%)$ & $\begin{array}{l}23 \\
(76.7 \%)\end{array}$ & $12(40 \%)$ & 0.117 \\
\hline & Male & $12(40 \%)$ & $7(23.3 \%)$ & $18(60 \%)$ & \\
\hline $\begin{array}{l}\text { Age (years) median } \\
\quad(\mathrm{p} 25 / \mathrm{p} 75)\end{array}$ & & $47(31 / 57)$ & $\begin{array}{l}46^{\mathrm{a}}(33 / \\
56)\end{array}$ & $55^{\mathrm{b}}(45 / 59)$ & $0.029^{\mathrm{a}, \mathrm{b}}$ \\
\hline $\begin{array}{l}\text { Duration of disease } \\
\text { (years) median } \\
\text { (p25/p75) }\end{array}$ & & $9(2 / 18)$ & N.A. & N.A. & N.A. \\
\hline $\begin{array}{l}\text { Treatment of } \\
\text { serum } \\
\text { collection data }\end{array}$ & $\begin{array}{l}\text { Yes } \\
\text { No }\end{array}$ & $\begin{array}{l}25(83.3 \%) \\
5(16.7 \%)\end{array}$ & N.A. & N.A. & N.A. \\
\hline $\begin{array}{l}\text { Activity of disease } \\
\text { on the day of } \\
\text { serum } \\
\text { collection }\end{array}$ & $\begin{array}{l}\text { Yes } \\
\text { No }\end{array}$ & $\begin{array}{l}30(100 \%) \\
0(0 \%)\end{array}$ & N.A. & N.A. & N.A \\
\hline
\end{tabular}

PF: Pemphigus Foliaceus; p25: percentile 25th; p75: percentile 75th; N.A.: Not Applicable. relatives, and their neighbours for the SGE from A. aegypti $(P=0.320)$. On the other hand, PF patients presented higher levels of IgG antibodies against the SGEs from $S$. nigrimanum and $N$. neivai as compared to PF patients' neighbours $(P<0.001$ for both SGEs), but not as compared to $\mathrm{PF}$ patients' relatives ( $P=0.115$ and $P=0.552$, respectively). Higher levels of antibodies against the SGEs from S. nigrimanum and $N$. neivai were also found in $\mathrm{PF}$ patients' relatives as compared to $\mathrm{PF}$ patients' neighbours $(P<0.001)$. Levels of IgG against the SGEs from $S$. nigrimanum and $N$. neivai but not against the SGE from $A$. aegypti were significantly higher in PF patients who had not started immunosuppressive treatment or without treatment for at least 60 days as compared to patients under treatment $(P=0.007, P=0.019$, and $P=0.327$, respectively) (data not shown).

Levels of anti-DSG1 antibodies correlated positively with antibodies against the SGEs from $S$. nigrimanum and $N$. neivai $(\mathrm{r}=0.3277$, $P<0.001$; and $\mathrm{r}=0.3958, P<0.001$, respectively), but not with antibodies against the SGE from $A$. aegypti $(\mathrm{r}=-0.1515, P=0.154)$ (Fig. 4A). Antibodies against the SGEs from $S$. nigrimanum and $N$. neivai also correlated positively with anti-DSG1 in PF patients $(\mathrm{r}=0.3848$, $P=0.039$; and $\mathrm{r}=0.416, P=0.022$ respectively) (Fig. 4B). There was no correlation between the levels of antibodies against DSG1 and the SGE from each insect with the duration of the disease in PF patients ( $\mathrm{P}>0.05$ in all cases) (data not shown).

\section{Discussion}

The expansion of urban boundaries has been accompanied by increased occurrence of diseases (e.g., leishmaniasis) that had been previously restricted to rural areas (Tolezano, 1994), a phenomenon that seems to apply for our study. Population growth associated with expansion of agricultural production has resulted in urban invasion of forested regions. This scenario represents a new stage of human cohabitation with the local fauna, which had been previously confined to places outside the cities (Tolezano, 1994). Historically, PF was distributed in rural areas and in areas close to rivers, which reinforces the hypothesis that Simuliidae and/or Phlebotominae might be associated with PF (Abréu-Vélez et al., 2010; Aoki et al., 2004; Chiossi and Roselino, 2001; Diaz et al., 1989; Eaton et al., 1998; Roselino and Almeida, 1995).

The present study shows coincidental georeferenced maps of anthropophilic Simuliidae and Phlebotominae species and PF cases and proposes an epidemiological link between them (Abréu-Vélez et al., 2010; Chiossi and Roselino, 2001; Diaz et al., 1989; Roselino and Almeida, 1995). Spatial geographical distribution maps of Simuliidae, Phlebotominae, and PF cases overlap 34 municipalities. The epidemiological link between $S$. nigrimanum and $\mathrm{PF}$, described over 70 years ago in the municipality of Franca (Vieira, 1940), a well-defined focus of $\mathrm{PF}$ characterized as number 2 in Fig. 1, represents the first attempt to establish a relationship between Simuliidae and PF. The present study confirms that PF is still prevalent in Franca, as well as anthropophilic Simuliidae species. Unfortunately, we have not been able to collect Simuliidae species in the other well-defined focus of PF (municipalities numbered 1 and 3-6 in Fig. 1). However, the surrounding cities surveyed present populations of anthropophilic black fly species reported herein, so it is expected that $S$. nigrimanum populations inhabit streams and rivers in some of these municipalities.

Although $S$. nigrimanum has been more frequently associated with $\mathrm{PF}$, other anthropophilic species like $S$. pertinax and $S$. incrustatum are widely distributed in regions with reported PF cases. Previous studies have also mentioned that $S$. pertinax and $S$. incrustatum are present in the Limão Verde indigenous reserve, a region where Brazilian PF is significantly endemic (Eaton et al., 1998).

Simuliidae species have been related to PF on the basis of two main hypotheses: (i) black fly species could carry a virus, or (ii) salivary proteins may mimic DSG (Abréu-Vélez et al., 2010; Aoki et al., 2004; Chiossi and Roselino, 2001; Roselino and Almeida, 1995). Ribeiro et al. 


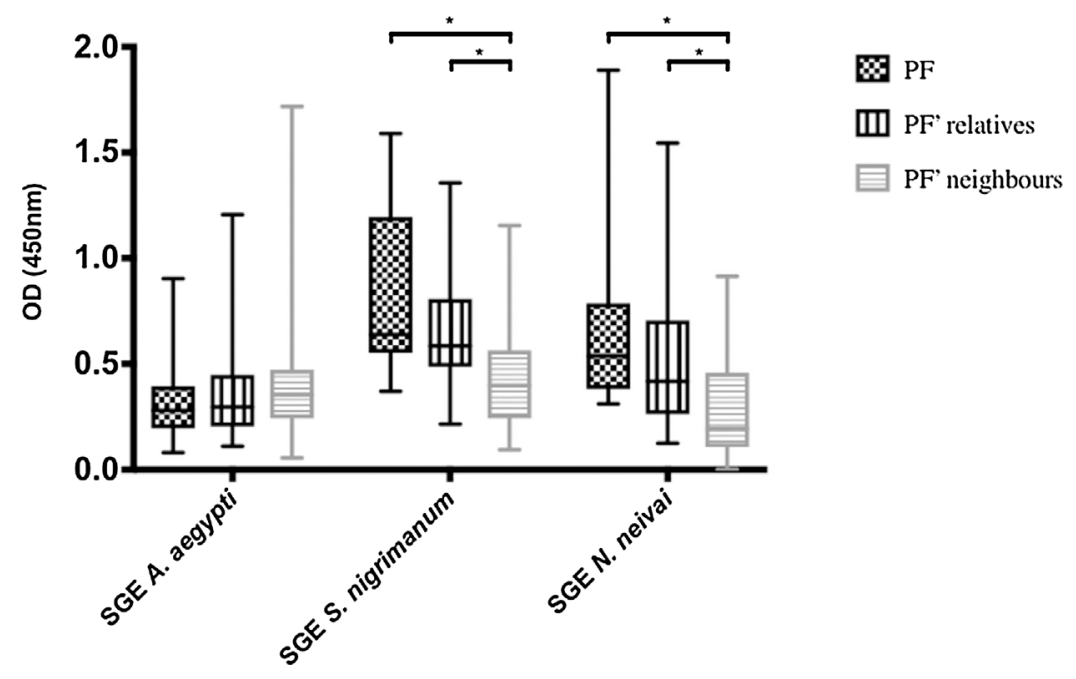

Fig. 3. In-house ELISA employing salivary gland extracts (SGEs) from Aedes aegypti, Simulium nigrimanum, and Nyssomyia neivai to evaluate the levels of IgG antibody in pemphigus foliaceus (PF) patients, PF patients' relatives, and PF patients' neighbours $\left({ }^{*} P<0.001\right)$.

\section{A \\ Three groups $(\mathrm{n}=90)$ \\ PF group ( $\mathbf{n = 3 0 )}$}
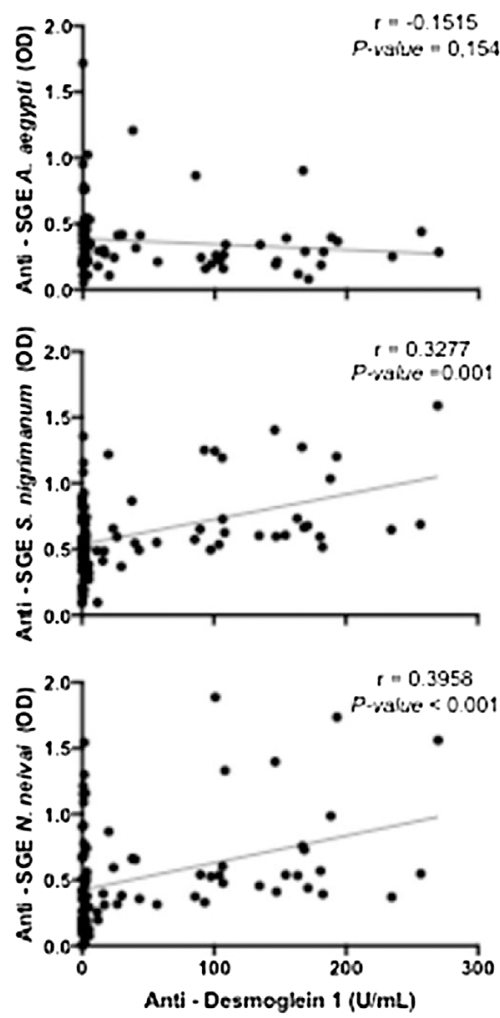
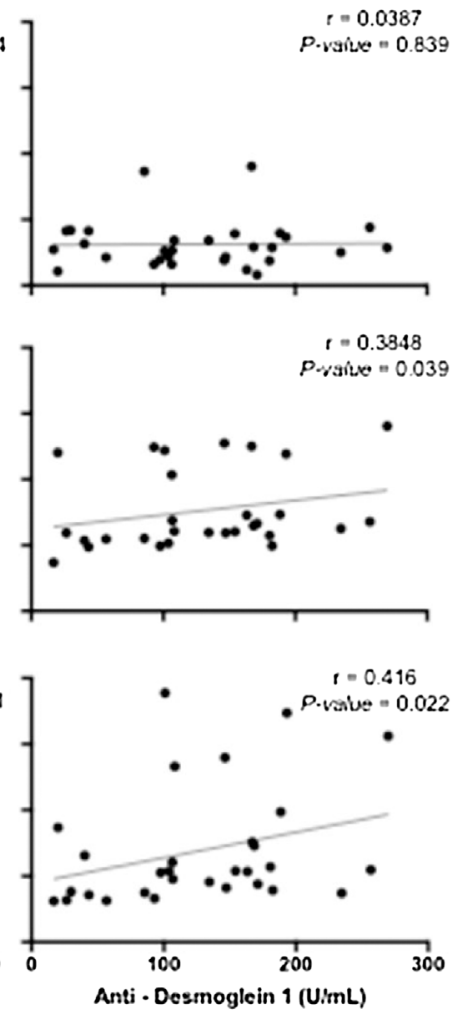

$r=0.0387$

Anti. Desmoglein 1 (UimL)
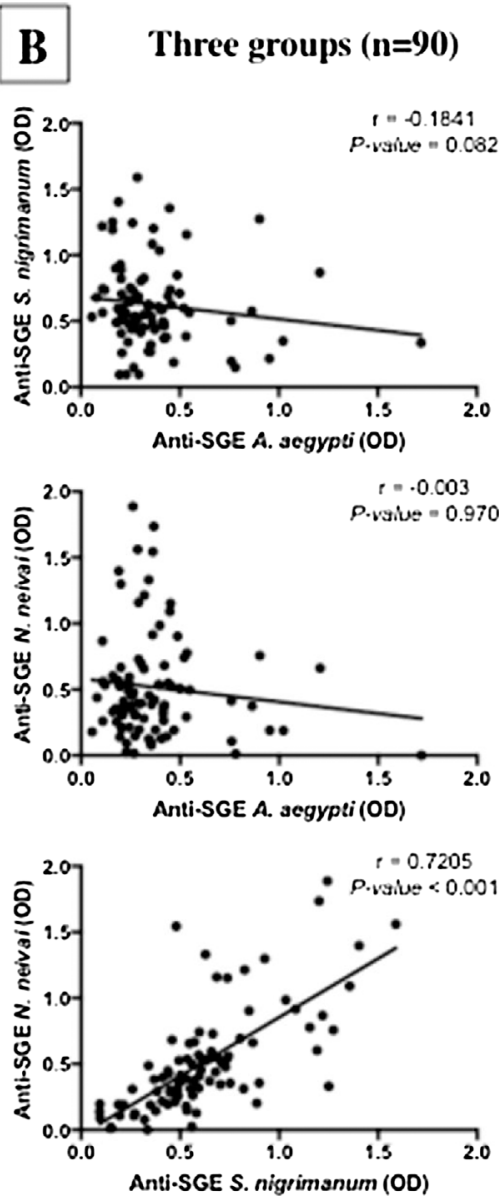

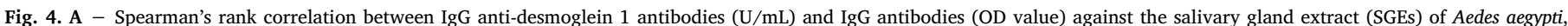

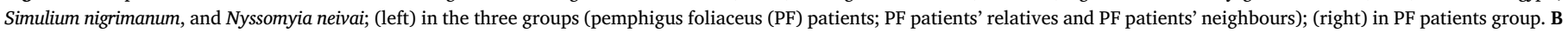

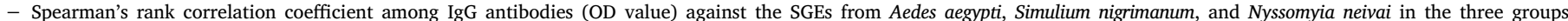

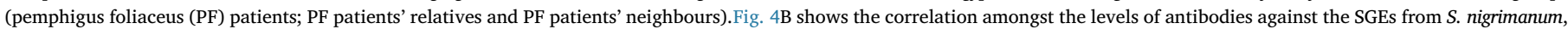

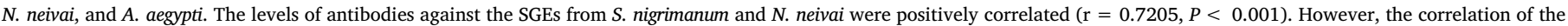

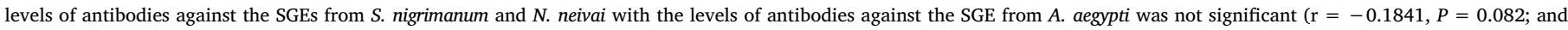
$\mathrm{r}=0.003, P=0.970$, respectively) (Fig. 4B).

have recently compared the peptide sequence of the $S$. nigrimanum sialotranscriptome with the peptide sequence of DSG to identify some candidate proteins that could induce anti-DSG cross-reactivity (Ribeiro et al., 2010). Although these authors found some similarity, no crossreactivity with salivary peptide has been proven so far. The sialotranscriptome analysis of other Simuliidae species is desirable because salivary proteins shared by the three species identified in NRSP could be recognized. Moreover, this analysis could uncover a putative black fly salivary antigenic mimicry with DSG. The positive correlation between anti-S. nigrimanum SGE with anti-DSG1 in PF patients suggests 
a possible cross-reactivity between antigens; notwithstanding, further studies are necessary to prove this possible mimicry and to find the precise salivary peptide that is involved in the process.

The involvement of the sandfly $L u$. longipalpis in PF has also been studied. This sandfly is an important vector of Leishmania infantum chagasi (Chagas \& Cunha, 1937), a parasite that causes VL in Brazil. Many reports have described the transmission of VL in some regions of São Paulo State (Casanova et al., 2015; Secretary of Health of Sao Paulo State, 2011). In the NRSP municipalities, Lu. longipalpis occurred without association with PF clusters (Fig. 2F). Roselino et al. (2001) (Roselino et al., 2001) have shown that sera collected from PF patients exhibit higher levels of IgG antibodies against maxadilan-a salivary protein from $\mathrm{Lu}$. Longipalpis-as compared to healthy controls living in the same endemic area. There is also evidence that the LJM11 salivary peptide from $\mathrm{Lu}$. longipalpis cross-reacts with antibodies against DSG1 (Qian et al., 2012). Furthermore, IgE antibodies against LJM11 have been proposed to trigger PF in some Amerindian populations living in endemic regions (Qian et al., 2015).

Nevertheless, $\mathrm{Lu}$. longipalpis is poorly distributed in the NRSP. Establishing an epidemiological link between LJM11 and PF in the NRSP would be ground-breaking. For this purpose, a LJM11-simile salivary peptide could be expressed in other biting fly species that inhabit NRSP, such as $N$. neivai, a vector of ATL in the studied region (Casanova et al., 2015). Recently, Ribeiro and our group have described the $N$. neivai sialotranscriptome (data not published - available in GenBank NCBI-NIH, USA (term: Nyssomyia neivai)), and surprisingly we did not find a LJM11-simile peptide, but 16 putative sequences of maxadilan-simile were described for $N$. neivai.

On the basis of the production of antibodies against the SGEs from $S$. nigrimanum and $N$. neivai but not against the SGE from $A$. aegypti, we have demonstrated that PF patients, PF patients' healthy relatives, and PF patients' neighbours living in the same area were exposed to bites by these flies, which has helped us to establish the epidemiological link. Remarkably, higher levels of IgG antibodies against the SGEs from $S$. nigrimanum and $N$. neivai but not against the SGE from $A$. aegypti have been detected in PF patients as compared to PF patients' neighbours. These results have led us to hypothesize that specific salivary gland proteins from black flies and sandflies, but not from mosquitoes possibly participate in PF. To our knowledge, no other study has dealt with exposure to $S$. nigrimanum bite or with the humoral response against its SGE.

The increased humoral response against the SGEs from $S$. nigrimanum and $N$. neivai in PF patients' relatives deserves attention. Genetic factors could be involved in this humoral response. In fact, three out of 30 PF patients' relatives but no PF patients' neighbours presented positive anti-DSG1 or antibodies against the SGEs from $S$. nigrimanum and $N$. neivai (data not shown); however, none of them have developed clinical PF yet. Further determination of the HLA susceptibility/protection profile of PF patients' relatives is necessary to compare it to the HLA profile of PF patients (Brochado et al., 2016).

Finally, it is important to discuss the positive correlation between the antibodies against the SGEs from $S$. nigrimanum and $N$. neivai in the three groups (PF patients; PF patients' relatives and PF patients' neighbours). This correlation shows that exposure to the bites of both species is possible because they are similarly distributed in NRSP. Nevertheless, the hypothesis of cross-reactivity between their salivary gland peptides should be carefully analysed. Although the two incriminated species are not closely related (Wiegmann et al., 2011), similar salivary proteins with similar antigen effects might be playing a role on PF pathogenesis

\subsection{Limitations of the study}

Because the data reported here have been compiled from a thirdlevel hospital, the number of PF cases could be underestimated due to lack of notification of pemphigus in Brazil and to possible treatment of patients at secondary healthcare level. Hence, we believe that the prevalence of PF in southeastern Brazil could be even higher.

Fig. 2 is a representative distribution of nine species of flies in NRSP; however, their distribution is obviously dynamic and might change over time. Ecological, epidemiological, and demographic transformations in NRSP could determine variations on the distribution of the different studied species in this region. Regarding the aim of this study, maps have been plotted for pedagogical and research purposes regarding PF cases for further selection of the most representative black fly and sandfly species in NRSP. Further ecological studies may provide fly population variations over the years.

No immunosuppressed PF patients presented higher levels of antibodies against the SGEs from $S$. nigrimanum and $N$. neivai or a tendency to have higher levels of anti-DSG1 as compared to patients under treatment. Therefore, immunosuppression treatment of $\mathrm{PF}$ patients could be underestimating the levels of anti-SGE IgG levels because the levels of anti-DSG1 decreased upon immunosuppression. Repeating the assays with PF patients that have never received any treatment is desirable.

\section{Conclusion}

PF cases and the spatial distribution of $S$. nigrimanum and $N$. neivai biting flies have shown defined geographical clusters in NRSP. Increased levels of IgG antibodies against the SGEs from $S$. nigrimanum and $N$. neivai in PF patients confirm exposure to fly bites, suggesting an epidemiological link between flies and PF in southeastern Brazil.

\section{Summary}

An epidemiological link between biting flies and Pemphigus Foliaceus (PF) in Brazil is proposed, implying a possible role of biting fly salivary gland proteins in $\mathrm{PF}$ etiopathogenesis.

\section{Financial statement}

This project was supported by FAPESP (Fundação de Apoio à Pesquisa do Estado de São Paulo \#2010/51729-2) and NAP-MOBIARVE (Núcleo de Pesquisa em Moléculas Bioativas de Artrópodes Vetores \#12.1.17661.1.7). S. Vernal received a PhD scholarship from CAPES (Coordenação de Aperfeiçoamento de Pessoal de Nível Superior). M. Pepinelli was a CNPq-CSF (Conselho Nacional de Desenvolvimento Científico e Tecnológico - Ciências Sem Fronteiras) fellow (\#205742/ 2014-9).

\section{Conflict of interest}

The authors have no conflicts of interest to declare.

\section{Acknowledgements}

The authors would like to thank Sandra Alexandre (Department of Immunology, Institute of Biomedical Sciences, University of Sao Paulo) and Beatriz Celere (Department of Maternal-Infant Nursing and Public Health, Ribeirão Preto Nursing School, University of São Paulo) for their technical assistance during the extraction of salivary glands and spatial mapping, respectively.

\section{Appendix A. Supplementary data}

Supplementary data associated with this article can be found, in the online version, at http://dx.doi.org/10.1016/j.actatropica.2017.09. 015. 


\section{References}

Abréu-Vélez, A.M., Roselino, A.M., Howard, M.S., Reason, I.J., 2010. Endemic pemphigus over a century: part II. N. Am. J. Med. Sci. 2, 114-125.

Adler, P.H., Crosskey, R.W., 2015. World Blackflies (Diptera: Simuliidae): a Comprehensive Revision of the Taxonomic and Geographical Inventory 015. Available in: http://www.clemson.edu/cafls/biomia/pdfs/blackflyinventory.pdf. (Accessed in March 21st, 2017).

Andrade Filho J.D., Galati E.A., Falcão A.L., 2007. Nyssomyia intermedia (Lutz \& Neiva, 1912) and Nyssomyia neivai (Pinto, 1926) (Diptera: Psychodidae: Phlebotominae) geographical distribution and epidemiological importance. Mem. Inst. Oswaldo Cruz 102, 481-487.

Aoki, V., Millikan, R.C., Rivitti, E.A., Hans-Filho, G., Eaton, D.P., Warren, S.J., Li, N., Hilario-Vargas, J., Hoffmann, R.G., Diaz, L.A., Research, C.G.o.F.S., 2004 Environmental risk factors in endemic pemphigus foliaceus (fogo selvagem). J Invest Dermatol. Symp. Proc. 9, 34-40.

Bizzarro, B., Barros, M.S., Maciel, C., Gueroni, D.I., Lino, C.N., Campopiano, J., Kotsyfakis, M., Amarante-Mendes, G.P., Calvo, E., Capurro, M.L., Sá-Nunes, A., 2013. Effects of Aedes aegypti salivary components on dendritic cell and lymphocyte biology. Parasit. Vectors 6, 329.

Brochado, M.J., Nascimento, D.F., Campos, W., Deghaide, N.H., Donadi, E.A., Roselino, A.M., 2016. Differential HLA class I and class II associations in pemphigus foliaceus and pemphigus vulgaris patients from a prevalent Southeastern Brazilian region. J. Autoimmun. 72, 19-24.

Casanova, C., Shimabukuro, P.H.F., Bressiani, B.A., Lazari, T.F., Galati, E.A.B., 2014. Geographial Distribution of Nyssomyia Neivai (Pinto) and Nyssomyia Intermedia (Lutz \& Neiva) in the State of São Paulo, Brazil. VIII International Symposium on Phlebotomine Sandflies, Puerto Iguazú, Misiones, Argentina. Abstract Book ID 171-P.

Casanova, C., Colla-Jacques, F.E., Hamilton, J.G., Brazil, R.P., Shaw, J.J., 2015. Distribution of lutzomyia longipalpis chemotype populations in São paulo state, Brazil. PLoS Negl Trop Dis 9, e0003620.

Celere, B., Vernal, S., La Serra, L., Brochado, M.J., Moschini, L.E., Roselino, A.M., SeguraMuñoz, S., 2017. Spatial distribution of pemphigus occurrence over five decades in southeastern Brazil. Am. J. Trop. Med. Hyg. http://dx.doi.org/10.4269/ajtmh.170100. in press.

Chiossi, M.P., Roselino, A.M., 2001. Endemic Pemphigus foliaceus (Fogo selvagem): a series from the Northeastern region of the State of São Paulo, Brazil, 1973-1998. Rev. Inst. Med. Trop. Sao Paulo 43, 59-62.

Diaz, L.A., Sampaio, S.A., Rivitti, E.A., Martins, C.R., Cunha, P.R., Lombardi, C., Almeida, F.A., Castro, R.M., Macca, M.L., Lavrado, C., 1989. Endemic pemphigus foliaceus (Fogo Selvagem): II: Current and historic epidemiologic studies. J. Invest. Dermatol. 92, 4-12.

Eaton, D.P., Diaz, L.A., Hans-Filho, G., Santos, V.D., Aoki, V., Friedman, H., Rivitti, E.A., Sampaio, S.A., Gottlieb, M.S., Giudice, G.J., Lopez, A., Cupp, E.W., 1998. Comparison of black fly species (Diptera: simuliidae) on an Amerindian reservation with a high prevalence of fogo selvagem to neighbouring disease-free sites in the State of Mato Grosso do Sul, Brazil. The Cooperative Group on Fogo Selvagem Research. J. Med. Entomol. 35, 120-131.

Galati, E.A.B., 2003. In: Rangel, E.R., Lainson, R. (Eds.), Classificação De Phlebotominae. In: Rangel and Lainson Flebotomíneos Do Brasil. Rio de Janeiro: Editora Fiocruz, pp. 23-51.

Glasser, C.M., de Castro Gomes, A., 2000. Infestation of S. paulo state Brazil, by aedes aegypti and aedes albopictus. Rev. Saude Publica 34, 570-577.

Hamada, N., Pepinelli, M., 2004. Simulium (Chirostilbia) bifenestratum (Diptera, Simuliidae), a new black-fly species from Atlantic Forest, state of São Paulo, Brazil. Mem. Inst. Oswaldo Cruz. 99, 45-52.

Hans-Filho, G., dos Santos, V., Katayama, J.H., Aoki, V., Rivitti, E.A., Sampaio, S.A., et al.,
1996. An active focus of high prevalence of fogo selvagem on an Amerindian reservation in Brazil. Cooper. Gr. Fogo Selvagem Res. J. Invest. Dermatol. 107, 68-75. Instituto Brasileiro de Geografia e Estatística (IBGE), 2017. Indicadores Demográficos. (Available at: http://www.cidades.ibge.gov.br. Accessed March 22 2017).

Lerner, E.A., Ribeiro, J.M., Nelson, R.J., Lerner, M.R., 1991. Isolation of maxadilan, a potent vasodilatory peptide from the salivary glands of the sand fly Lutzomyia longipalpis. J. Biol. Chem. 266, 11234-11236.

Lombardi, C., Borges, P.C., Chaul, A., Sampaio, S.A., Rivitti, E.A., Friedman, H., Martins, C.R., Sanches Júnior, J.A., Cunha, P.R., Hoffmann, R.G., 1992. Environmental risk factors in endemic pemphigus foliaceus (Fogo selvagem): the cooperative group on fogo selvagem research. J. Invest. Dermatol. 98, 847-850.

Marcondes, C.B., 2007. A proposal of generic and subgeneric abbreviations for phlebotomine sandflies (Diptera: psychodidae: Phlebotominae) of the world. Entomol. News $118,151-156$.

Pepinelli, M., 2008. Simuliidae (Diptera, Nematocera) do Estado de São Paulo. Doctoral thesis (Biological Sciences). Federal University of São Carlos, São Carlos-SP, Brazil.

Qian, Y., Jeong, J.S., Maldonado, M., Valenzuela, J.G., Gomes, R., Teixeira, C., Evangelista, F., Qaqish, B., Aoki, V., Hans, G., Rivitti, E.A., Eaton, D., Diaz, L.A., 2012. Cutting Edge: brazilian pemphigus foliaceus anti-desmoglein 1 autoantibodies cross-react with sand fly salivary LJM11 antigen. J. Immunol. 189, 1535-1539.

Qian, Y., Jeong, J.S., Abdeladhim, M., Valenzuela, J.G., Aoki, V., Hans-Filhio, G., Rivitti, E.A., Diaz, L.A., Research, C.G.o.F.S., 2015. IgE anti-LJM11 sand fly salivary antigen may herald the onset of fogo selvagem in endemic Brazilian regions. J. Invest. Dermatol. 135, 913-915.

Ribeiro, J.M., Valenzuela, J.G., Pham, V.M., Kleeman, L., Barbian, K.D., Favreau, A.J., Eaton, D.P., Aoki, V., Hans-Filho, G., Rivitti, E.A., Diaz, L.A., 2010. An insight into the sialotranscriptome of Simulium nigrimanum, a black fly associated with fogo selvagem in South America. Am. J. Trop. Med. Hyg. 82, 1060-1075.

Roselino, A.M., Almeida, A.M., 1995. Surto de pênfigo foliáceo endêmico em instituição para menores em Batatais, Estado de São Paulo, Brasil, 1988-1990. Medicina (Ribeirão Preto) 28, 44-50.

Roselino, A.M., Figueiredo, J.F.C., Kounga, K., Reddy, V., Lerner, E.A., 2001. Serum IgG from pemphigus foliaceus patients reacts against maxadilan. J. Invest. Dermatol. 117, 460.

Secretary of Health of São Paulo State, 2008. Leishmaniose Tegumentar Americana, Situação Atual. Available in: http://www.saude.sp.gov.br/sucen-superintendenciade-controle-de-endemias/programas/leishmaniose-tegumentar-americana/situacaoatual (Accessed in March 21st, 2017).

Secretary of Health of São Paulo State, 2011. Epidemiological Classification of Cities According to the Program of Surveillance and Control of American Visceral Leishmaniasis in the State of São Paulo, Updated in November, Boletim Epidemiológico Paulista.

Souza, A.P., Andrade, B.B., Aquino, D., Entringer, P., Miranda, J.C., Alcantara, R., Ruiz, D., Soto, M., Teixeira, C.R., Valenzuela, J.G., de Oliveira, C.I., Brodskyn, C.I., BarralNetto, M., Barral, A., 2010. Using recombinant proteins from Lutzomyia longipalpis saliva to estimate human vector exposure in visceral Leishmaniasis endemic areas. PLoS Negl. Trop. Dis. 4, e649.

Tolezano, J.E., 1994. Ecoepidemiological aspects of American cutaneous leishmaniasis in the state of São Paulo, Brazil. Mem. Inst. Oswaldo Cruz. 89, 427-434.

Vieira, J., 1940. Pemphigus foliaceus (fogo selvagem) - an endemic disease in the state of Sao Paulo (Brazil). Arch. Dermatol. Syphilol. 41, 858-863.

Wiegmann, B.M., Trautwein, M.D., Winkler, I.S., Barr, N.B., Kim, J.-W., et al., 2011 Episodic radiation in the fly tree of life. Proc. Natl. Acad. Sci. USA 108, 5690-5695.

Zaraa, I., Boussoffara, T., Ben Ahmed, M., Marzouki, S., Ben Hassouna, N., Sellami, M.K., Makni, S., Ben Osman, A., Louzir, H., Mokni, M., 2012. Exposure to Phlebotomus papatasi and/or Leishmania major: possible etiologic link to Tunisian pemphigus. J. Invest. Dermatol. 132, 479-482. 


\section{Supplementary Materials and Methods}

To assess in-house ELISA performance, we immunized three female rabbits with each salivary glands extract (SGE) respectively.

Rabbit immunization against salivary gland extract (SGE). Briefly, SGE ( $40 \mu \mathrm{g} / \mathrm{mL})$ were diluted in PBS to a final volume of $2 \mathrm{~mL}$, distributed into $500 \mu \mathrm{L}$ aliquots. On the first day, $500 \mu \mathrm{L}$ of Complete Freund's adjuvant (Sigma-Aldrich®, Saint Louis, MO, USA) was mixed with an aliquot of SGE/PBS, and the rabbit was injected in each hip. Nine days later, another dose was injected in the foreleg and shoulder of the rabbit. On day $20^{\text {th }}$, a third dose was injected in four subcutaneous points. Immunization was confirmed by counterimmunoelectrophoresis on $1 \%$ agarose gel to confront rabbit serum before and after immunization (positive pole) against each SGE respectively (negative pole). Runs were accomplished in sodium barbital buffer at an electric current of $30 \mathrm{~mA}$, for $60 \mathrm{~min}$, and then agarose gel was stained with Coomassie Blue (Sigma-Aldrich ${ }^{\circledR}$, Saint Louis, MO, USA).

ELISA dose-curve analysis. In-house ELISA was standardizing comparing pre- and postimmunize rabbit sera. Briefly, 11 serial dilutions of each SGE $(10,000 \mathrm{ng}$ to $9,37 \mathrm{ng})$ were pre-incubated overnight in 96-well micro-plates (Costar $®)$, and then blocked for $1 \mathrm{~h}$ with PBS1X/Tween 0.005\%/BSA 1\%. Rabbit' sera pre- and post-immunization were diluted 1:50 and 1:100 in PBS1X/Tween $0.005 \% / \mathrm{BSA} 1 \%$, followed by two serial dilution of secondary antibody (anti-rabbit IgG, Abcam $\left.{ }^{\circledR}\right) \quad(1: 5,000$ and 1:10,000 for both primary antibody dilutions). Rabbit' sera were pipetted in duplicate. Lecture was done at $450 \mathrm{~nm}$. Best performance was obtained with 300ng of SGE for three insects, primary antibody dilution of 1:100 and secondary antibody 1:10,000. Positive (post immunization rabbit) and negative (pre immunization rabbit) values were as follow: 2.049/0.136 (OD), 2.321/0.182 (OD), and 2.154/0.172 (OD) for Ae. aegypti, S. nigrimanum and $N y$. neivai micro-plaques, respectively. 
SUPPLEMENTARY TABLE 1S

\begin{tabular}{|c|c|c|c|c|c|c|c|c|c|}
\hline Patient & Sex & $\begin{array}{c}\text { Age at serum } \\
\text { collection } \\
\text { (years) }\end{array}$ & $\begin{array}{l}\text { Time of } \\
\text { disease } \\
\text { (Years) }\end{array}$ & $\begin{array}{c}\text { PF activity at } \\
\text { serum } \\
\text { collection }\end{array}$ & $\begin{array}{c}\text { Treatment at } \\
\text { serum } \\
\text { collection } \\
\end{array}$ & $\begin{array}{c}\text { ELISA anti- } \\
\text { DSG1 } \\
(\mathbf{U} / \mathbf{m L}) \\
\end{array}$ & $\begin{array}{c}\text { ELISA anti-SGE } \\
\text { S. nigrimanum } \\
\text { (OD) }\end{array}$ & $\begin{array}{l}\text { ELISA anti- } \\
\text { SGE } N \text {. neivai } \\
\text { (OD) }\end{array}$ & $\begin{array}{c}\text { ELISA anti-SGE } \\
\text { A. aegypti (OD) }\end{array}$ \\
\hline PF1 & $\mathrm{F}$ & 25 & 9 & Yes & Yes & 106,340 & 1,192 & 0,605 & 0,161 \\
\hline PF2 & $\mathrm{F}$ & 59 & $<1$ & Yes & Yes & 92,850 & 1,251 & 0,331 & 0,160 \\
\hline PF3 & $\mathrm{M}$ & 28 & $<1$ & Yes & Virgin & 193,039 & 1,202 & 1,736 & 0,367 \\
\hline PF4 & $\mathrm{F}$ & 58 & 49 & Yes & Yes & 56,679 & 0,552 & 0,314 & 0,212 \\
\hline PF5 & $\mathrm{M}$ & 32 & 12 & Yes & Virgin & 146,284 & 1,404 & 1,398 & 0,191 \\
\hline PF6 & $\mathrm{M}$ & 39 & 23 & Yes & $\mathrm{No}^{*}$ & 134,425 & 0,605 & 0,456 & 0,343 \\
\hline PF7 & $\mathrm{M}$ & 31 & 22 & Yes & Yes & 147,319 & 0,597 & 0,411 & 0,215 \\
\hline PF8 & $\mathrm{F}$ & 17 & $<1$ & Yes & Yes & 103,857 & 0,536 & 0,538 & 0,222 \\
\hline PF9 & $\mathrm{M}$ & 56 & 11 & Yes & Yes & 182,408 & 0,515 & 0,393 & 0,287 \\
\hline PF10 & $\mathrm{F}$ & 52 & 22 & Yes & Yes & 20,151 & 1,219 & 0,868 & 0,108 \\
\hline PF11 & $\mathrm{M}$ & 34 & 20 & Yes & Yes & 154,264 & 0,608 & 0,539 & 0,393 \\
\hline PF12 & $\mathrm{F}$ & 73 & 5 & Yes & Yes & 43,472 & 0,494 & 0,358 & 0,415 \\
\hline PF13 & $\mathrm{F}$ & 37 & 2 & Yes & Yes & 29,952 & 0,369 & 0,383 & 0,420 \\
\hline PF14 & $\mathrm{F}$ & 55 & 2 & Yes & Yes & 108,307 & 0,628 & 1,330 & 0,342 \\
\hline PF15 & $\mathrm{M}$ & 71 & 10 & Yes & Yes & 171,166 & 0,679 & 0,439 & 0,080 \\
\hline PF16 & $\mathrm{F}$ & 48 & 17 & Yes & Yes & 100,958 & 1,244 & 1,888 & 0,262 \\
\hline PF17 & $\mathrm{M}$ & 17 & 8 & Yes & Yes & 85,543 & 0,574 & 0,375 & 0,864 \\
\hline PF18 & $\mathrm{M}$ & 18 & $<1$ & Yes & Yes & 26,570 & 0,594 & 0,318 & 0,415 \\
\hline PF19 & $\mathrm{M}$ & 66 & 3 & Yes & Yes & 106,763 & 0,729 & 0,477 & 0,265 \\
\hline PF20 & $\mathrm{F}$ & 73 & 3 & Yes & Yes & 180,637 & 0,594 & 0,570 & 0,187 \\
\hline PF21 & $\mathrm{M}$ & 17 & $<1$ & Yes & Virgin & 166,879 & 1,274 & 0,758 & 0,903 \\
\hline PF22 & $\mathrm{F}$ & 57 & 4 & Yes & Yes & 234,522 & 0,649 & 0,371 & 0,251 \\
\hline PF23 & $\mathrm{M}$ & 62 & 23 & Yes & Yes & 256,561 & 0,690 & 0,547 & 0,440 \\
\hline PF24 & $\mathrm{F}$ & 33 & 1 & Yes & Virgin & 269,809 & 1,589 & 1,561 & 0,286 \\
\hline PF25 & $\mathrm{F}$ & 36 & 11 & Yes & Yes & 188,408 & 1,034 & 0,985 & 0,397 \\
\hline PF26 & $\mathrm{F}$ & 49 & $<1$ & Yes & Yes & 168,384 & 0,665 & 0,729 & 0,291 \\
\hline PF27 & $\mathrm{F}$ & 54 & 9 & Yes & Yes & 97,643 & 0,495 & 0,526 & 0,195 \\
\hline PF28 & $\mathrm{F}$ & 38 & 9 & Yes & Yes & 40,236 & 0,547 & 0,656 & 0,317 \\
\hline PF29 & $\mathrm{F}$ & 46 & 18 & Yes & Yes & 163,289 & 0,734 & 0,534 & 0,120 \\
\hline PF30 & $\mathrm{F}$ & 49 & 35 & Yes & Yes & 16,959 & 0,487 & 0,310 & 0,273 \\
\hline
\end{tabular}

* Without immunosuppressor treatment for more than 60 days. PF: Pemphigus Foliaceus; F: Female; M: Male; DSG1: Desmoglein 1; SGE: Salivary Gland Extrac OD: Optical Density 
SUPPLEMENTARY TABLE $2 S$

\begin{tabular}{|c|c|c|c|c|c|c|}
\hline Patient & Sex & $\begin{array}{c}\text { Age at } \\
\text { collection }\end{array}$ & $\begin{array}{c}\text { ELISA anti- } \\
\text { DSG1 } \\
(\mathrm{U} / \mathrm{mL})\end{array}$ & $\begin{array}{c}\text { ELISA anti-SGE } S \text {. } \\
\text { nigrimanum } \\
(\mathrm{OD})\end{array}$ & $\begin{array}{c}\text { ELISA anti-SGE } \\
\text { N. neivai } \\
\text { (OD) }\end{array}$ & $\begin{array}{c}\text { ELISA anti-SGE } \\
\text { A. aegypti (OD) }\end{array}$ \\
\hline Relative 1 & $\mathrm{M}$ & 14 & 1,012 & 1,356 & 1,090 & 0,448 \\
\hline Relative 2 & $\mathrm{~F}$ & 48 & 0,935 & 0,804 & 0,694 & 0,304 \\
\hline Relative 3 & $\mathrm{~F}$ & 47 & 0,389 & 0,502 & 0,414 & 0,759 \\
\hline Relative 4 & $\mathrm{~F}$ & $\S$ & 2,784 & 0,562 & 0,497 & 0,548 \\
\hline Relative 5 & $\mathrm{M}$ & 42 & 89,658 & 0,652 & 0,541 & 0,244 \\
\hline Relative 6 & $\mathrm{~F}$ & 56 & 37,868 & 0,867 & 0,663 & 1,207 \\
\hline Relative 7 & $\mathrm{~F}$ & 46 & 1,114 & 0,451 & 0,280 & 0,316 \\
\hline Relative 8 & $\mathrm{~F}$ & 64 & 0,080 & 0,573 & 0,667 & 0,200 \\
\hline Relative 9 & $\mathrm{~F}$ & $\S$ & 1,591 & 0,481 & 1,545 & 0,363 \\
\hline Relative 10 & $\mathrm{~F}$ & 39 & 3,421 & 0,597 & 0,743 & 0,520 \\
\hline Relative 11 & $\mathrm{~F}$ & 38 & 2,068 & 0,704 & 0,344 & 0,207 \\
\hline Relative 12 & $\mathrm{~F}$ & 42 & 0,000 & 0,887 & 0,202 & 0,204 \\
\hline Relative 13 & $\mathrm{~F}$ & 60 & 0,796 & 0,738 & 1,152 & 0,452 \\
\hline Relative 14 & $\mathrm{M}$ & 59 & 1,671 & 0,451 & 0,304 & 0,273 \\
\hline Relative 15 & $\mathrm{~F}$ & 57 & 1,962 & 0,821 & 0,312 & 0,204 \\
\hline Relative 16 & $\mathrm{~F}$ & 32 & 23,707 & 0,658 & 0,595 & 0,244 \\
\hline Relative 17 & $\mathrm{~F}$ & 18 & 0,160 & 0,442 & 0,423 & 0,370 \\
\hline Relative 18 & $\mathrm{M}$ & 31 & 1,597 & 0,488 & 0,264 & 0,417 \\
\hline Relative 19 & $\mathrm{M}$ & 46 & 0,121 & 0,709 & 0,507 & 0,499 \\
\hline Relative 20 & $\mathrm{~F}$ & 57 & 0,604 & 0,899 & 0,356 & 0,176 \\
\hline Relative 21 & $\mathrm{~F}$ & 38 & 11,353 & 0,489 & 0,255 & 0,179 \\
\hline Relative 22 & $\mathrm{M}$ & 38 & 3,694 & 0,508 & 0,377 & 0,216 \\
\hline Relative 23 & $\mathrm{~F}$ & 29 & 0,764 & 0,408 & 0,218 & 0,205 \\
\hline Relative 24 & $\mathrm{M}$ & 18 & 0,127 & 0,564 & 0,260 & 0,111 \\
\hline Relative 25 & $\mathrm{~F}$ & 49 & 0,764 & 0,826 & 1,214 & 0,319 \\
\hline Relative 26 & $\mathrm{~F}$ & 57 & 1,054 & 0,535 & 0,148 & 0,273 \\
\hline Relative 27 & $\mathrm{~F}$ & 15 & 0,000 & 0,215 & 0,190 & 0,953 \\
\hline Relative 28 & $\mathrm{~F}$ & 81 & 5,219 & 0,272 & 0,125 & 0,342 \\
\hline Relative 29 & $\mathrm{~F}$ & 41 & 1,661 & 0,927 & 1,299 & 0,200 \\
\hline Relative 30 & $\mathrm{~F}$ & 35 & 2,510 & 0,685 & 1,160 & 0,290 \\
\hline Neighbour 1 & $\mathrm{M}$ & 58 & 5,330 & 0,384 & 0,293 & 0,532 \\
\hline Neighbour 2 & $\mathrm{M}$ & 18 & 3,500 & 0,350 & 0,189 & 1,022 \\
\hline Neighbour 3 & $\mathrm{M}$ & $\S$ & 2,653 & 0,341 & 0,488 & 0,238 \\
\hline Neighbour 4 & $\mathrm{~F}$ & 45 & 1,129 & 0,459 & 0,683 & 0,421 \\
\hline
\end{tabular}




\begin{tabular}{|c|c|c|c|c|c|c|}
\hline Neighbour 5 & $\mathrm{M}$ & 65 & 11,947 & 0,095 & 0,196 & 0,294 \\
\hline Neighbour 6 & $\mathrm{~F}$ & 54 & 1,129 & 0,150 & 0,017 & 0,267 \\
\hline Neighbour 7 & $\mathrm{~F}$ & 53 & 0,753 & 0,150 & 0,013 & 0,781 \\
\hline Neighbour 8 & $\mathrm{~F}$ & 60 & 0,719 & 0,534 & 0,387 & 0,356 \\
\hline Neighbour 10 & M & 44 & 0,160 & 0,096 & 0,091 & 0,230 \\
\hline Neighbour 11 & $\mathrm{~F}$ & 44 & 0,399 & 0,188 & 0,192 & 0,469 \\
\hline Neighbour 14 & $\mathrm{M}$ & 56 & 1,811 & 0,559 & 0,026 & 0,228 \\
\hline Neighbour 15 & $\mathrm{~F}$ & 67 & 0,000 & 0,582 & 0,127 & 0,405 \\
\hline Neighbour 16 & $\mathrm{~F}$ & 57 & 2,077 & 0,474 & 0,213 & 0,245 \\
\hline Neighbour 17 & $\mathrm{~F}$ & 51 & 1,656 & 0,438 & 0,449 & 0,258 \\
\hline Neighbour 18 & $\mathrm{M}$ & 44 & 0,127 & 0,094 & 0,139 & 0,196 \\
\hline Neighbour 23 & $\mathrm{M}$ & 40 & 1,756 & 0,259 & 0,309 & 0,208 \\
\hline Neighbour 24 & $\mathrm{M}$ & 62 & 2,357 & 0,438 & 0,194 & 0,376 \\
\hline Neighbour 25 & $\mathrm{M}$ & 71 & 15,993 & 0,412 & 0,395 & 0,303 \\
\hline Neighbour 26 & 0 & 51 & 0,505 & 0,531 & 0,180 & 0,056 \\
\hline Neighbour 27 & $\mathrm{M}$ & 60 & 2,990 & 0,625 & 0,522 & 0,458 \\
\hline Neighbour 28 & $\mathrm{M}$ & 65 & 1,495 & 0,267 & 0,107 & 0,352 \\
\hline Neighbour 29 & M & 52 & 1,163 & 1,084 & 0,915 & 0,362 \\
\hline Neighbour 30 & $\mathrm{M}$ & 55 & 1,827 & 0,195 & 0,108 & 0,760 \\
\hline
\end{tabular}

$\S$ Missing value; F: Female; M: Male; DSG1: Desmoglein 1; SGE: Salivary Gland Extract; OD: Optical Density 


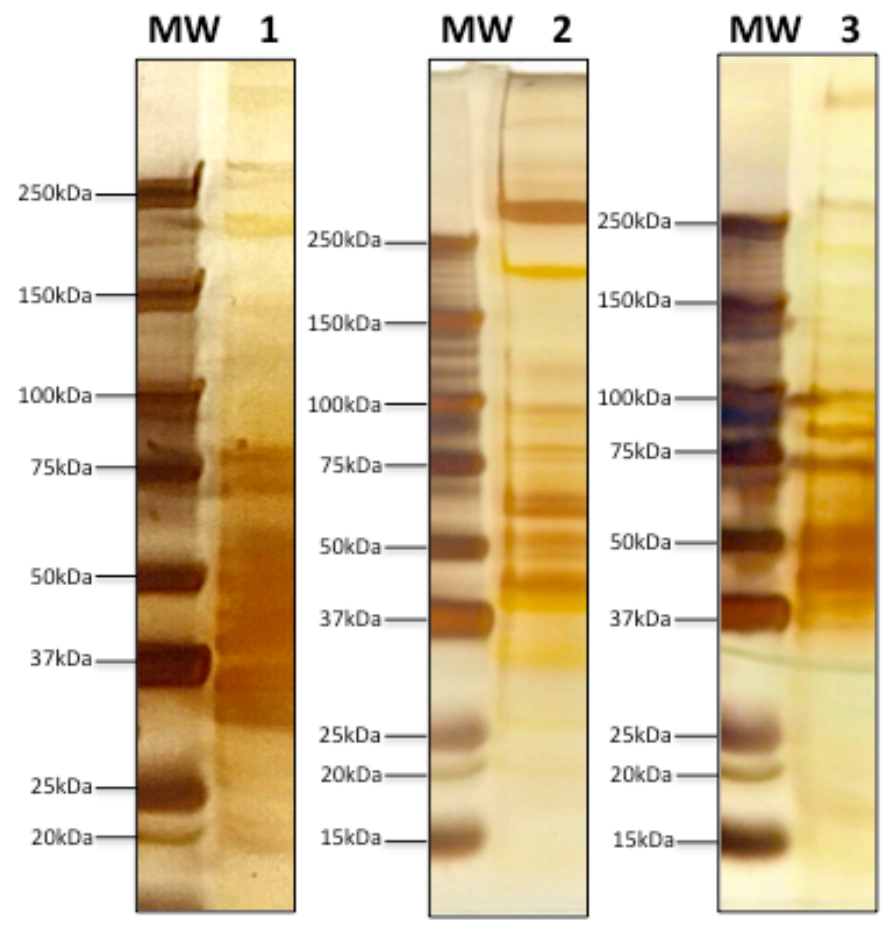

Supplementary Figure 1S. Electrophoresis of salivary glands extracts (SGE) in polyacrylamide 4-15\% gel (BioRad). MW: Molecular Weigh - Precision Plus protein TM dual-color (BioRad); 1: SGE of Simulium nigrimanum; 2: SGE of Nyssomyia neivai; 3: SGE of Aedes aegypti. 


\subsection{ARTIGOS SUBMETIDOS}

5.2.1 Relationship between $\operatorname{IgE}$ and salivary proteins from biting flies in pemphigus foliaceus. Jornal: Arquives of Dermatological Research. Fator de impacto: 2,309. Formato: Letter to the Editor

Relationship between IgE and salivary proteins from biting flies in pemphigus foliaceus

S. Vernal; M. Pepinelli; W. Oliveira; T. Goulart; M. Pinto; A. Sá-Nunes; A.M. Roselino 
Manuscript Number:

Full Title:

Article Type:

Keywords:

Corresponding Author:

Corresponding Author Secondary
Information:

Corresponding Author's Institution:

Corresponding Author's Secondary Institution:

First Author:

First Author Secondary Information:

Order of Authors:

\begin{tabular}{|l|} 
\\
\hline Order of Authors Secondary Information: \\
\hline Funding Information: \\
\hline
\end{tabular}

Funding Information:

Abstract:
AODR-D-19-00297

Relationship between IgE and salivary proteins from biting flies in pemphigus foliaceus Letter to the Editor

IMRE-D-19-00231

Sebastian Vernal, M.D.

Universidade de Sao Paulo

BRAZIL

Universidade de Sao Paulo

Sebastian Vernal, M.D., Ph.D.(c)

Sebastian Vernal, M.D., Ph.D.(c)

Mateus Pepinelli, Ph.D.

Wanderson Oliveira, Ph.D.

Thaís Goulart, Ph.D.

Mara Pinto, Ph.D.

Anderson Sá-Nunes, Ph.D.

Ana Maria Roselino, M.D., Ph.D.

Fundação de Amparo à Pesquisa do Estado de São Paulo

Prof. Ana Maria Roselino

Letter to the Editor 


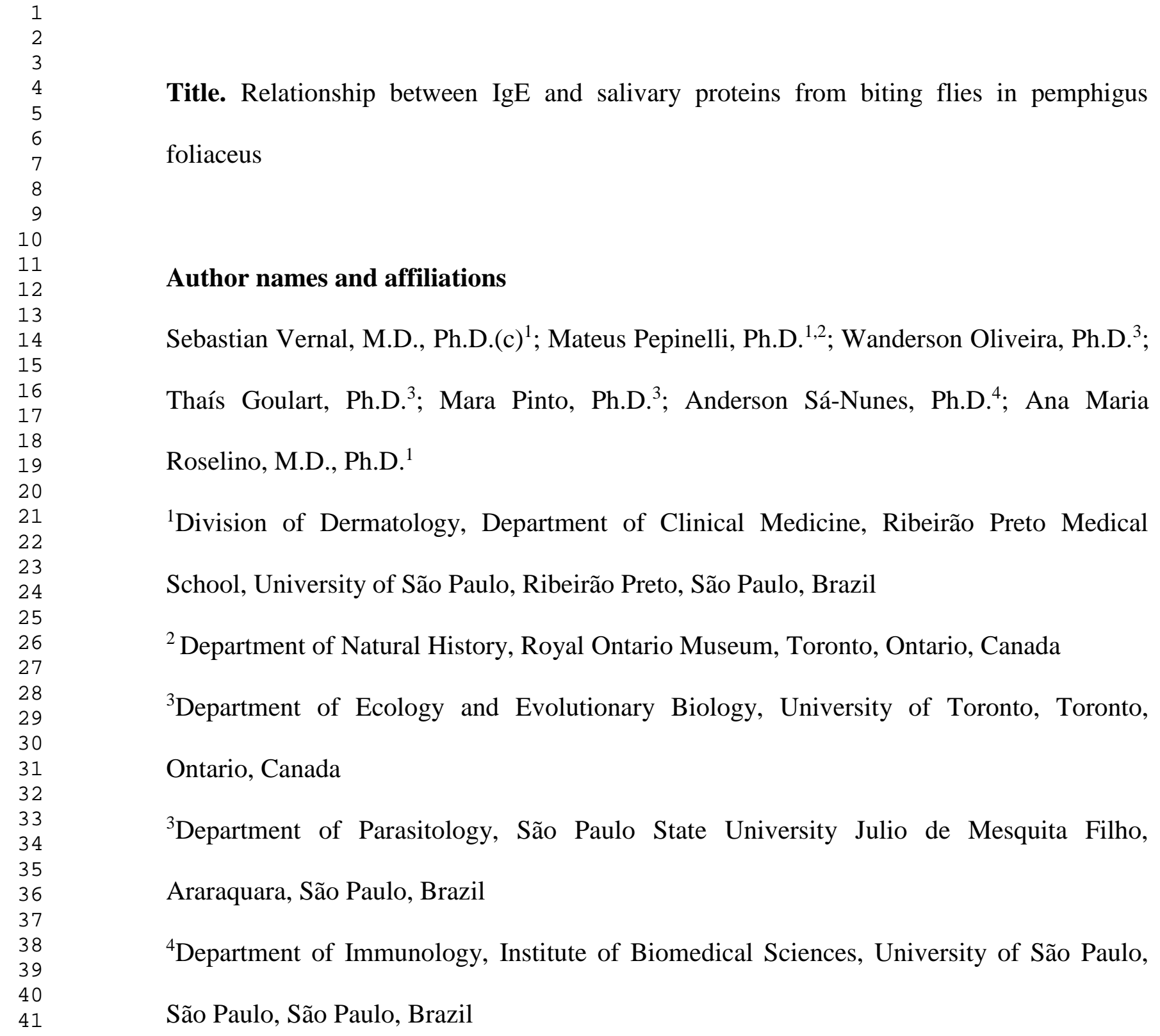

Title. Relationship between IgE and salivary proteins from biting flies in pemphigus foliaceus

\section{Author names and affiliations}

Sebastian Vernal, M.D., Ph.D.(c) ${ }^{1}$; Mateus Pepinelli, Ph.D. ${ }^{1,2}$; Wanderson Oliveira, Ph.D. ${ }^{3}$;

Thaís Goulart, Ph.D. ${ }^{3}$; Mara Pinto, Ph.D. ${ }^{3}$; Anderson Sá-Nunes, Ph.D. ${ }^{4}$; Ana Maria Roselino, M.D., Ph.D. ${ }^{1}$

${ }^{1}$ Division of Dermatology, Department of Clinical Medicine, Ribeirão Preto Medical School, University of São Paulo, Ribeirão Preto, São Paulo, Brazil

${ }^{2}$ Department of Natural History, Royal Ontario Museum, Toronto, Ontario, Canada

${ }^{3}$ Department of Ecology and Evolutionary Biology, University of Toronto, Toronto, Ontario, Canada

${ }^{3}$ Department of Parasitology, São Paulo State University Julio de Mesquita Filho, Araraquara, São Paulo, Brazil

${ }^{4}$ Department of Immunology, Institute of Biomedical Sciences, University of São Paulo, São Paulo, São Paulo, Brazil

\section{Corresponding author}

Sebastian Vernal, M.D. University Hospital, Ribeirão Preto Medical School, University of São Paulo. Av. Bandeirantes 3900, Monte Alegre, Ribeirão Preto, São Paulo - 14040-900). Phone number: +55.16.36022715. Fax number: +55.16.36023315. E-mail: vernal.carranza@gmail.com 


\section{To the editor,}

Well-defined geographical clusters of pemphigus foliaceus (PF) cases in Southeastern Brazil disclosed a prevalence of 57.5 patients per million people [1]. Historically, PF occurrence in Brazil has been recorded in rural areas; presence of biting flies might be associated with this condition [2,3]. Recently, we have demonstrated a geographical link between blood-sucking insects and PF cases diagnosed in this Brazilian endemic region [1]. Production of IgG antibodies against salivary gland extracts (SGEs) from the black fly Simulium nigrimanum and the sand fly Nyssomyia neivai, but not against SGE from the mosquito Aedes aegypti, by PF patients and their relatives (PFR) confirmed an epidemiological link between PF and biting flies. Moreover, IgG antibodies against SGEs from S. nigrimanum and N. neivai, but not SGE from A. aegypti, correlated with IgG anti-desmoglein 1 (Dsg1) autoantibodies in the PF group, which suggested an antigenic cross-reactivity [1].

A previous study reported that Brazilian PF patients had higher anti-Dsg1 IgE titres compared to healthy controls (HC), and that Brazilian controls exhibited higher anti-Dsg1 IgE titres compared to American and Japanese controls, which suggested that Brazilian PF patients and controls share some environmental antigens that raise $\operatorname{IgE}$ antibody production [4]. Another study provided strong evidence that antibodies against LJM11 (a highly immunogenic salivary peptide from the sand fly Lutzomyia longipalpis) cross-reacted with Dsg1 peptide [3]. In fact, it has been proposed that anti-LJM11 IgE could underlie PF triggering in some Amerindians living in PF endemic region [5].

In this study, we aimed to evaluate total serum $\operatorname{IgE}$ and $\operatorname{IgE}$ antibodies production against SGEs from A. aegypti, N. neivai, and S. nigrimanum in PF, PFR, and HC groups 
living in the same Brazilian PF endemic area. We also present the correlation between total $\operatorname{IgE}$ titres and $\operatorname{IgE}$ antibody titres production against each SGE.

Serum samples from $30 \mathrm{PF}$ patients, $30 \mathrm{PFR}$, and $30 \mathrm{HC}$ were used, as approved by the Local Ethics Committee on Human Research. For total $\operatorname{IgE}$ determination, 50 $\mu \mathrm{L}$ of serum sample was prepared by following the manufacturer's recommendations (ImmunoCAP ${ }^{\mathrm{TM}}$ Total IgE, Thermo-Fisher, USA) and read in Phadia100 laboratory system (Thermo-Fisher, USA). IgE antibodies specific for SGEs were evaluated by ELISA, as described previously [1]; replacement with secondary murine monoclonal antibody antihuman-IgE conjugated with HRP was carried out (Abcam, UK).

Compared to PFR and HC, total IgE levels in the serum were higher in PF patients (Kruskall-Wallis followed by Dunn's test: $P<0.001)$ (Figure 1A). In fact, $28(93.3 \%)$ of 30 PF patients displayed IgE frequencies above the cut-off value $(100 \mathrm{kU} / \mathrm{L})$ as compared to 10 $(33.3 \%)$ PFR and $14(46.6 \%) \mathrm{HC}$ (chi-square test: $P<0.001)$. Most PF patients $(83.3 \%)$ were under treatment at the moment of serum collection. PF patients who had not started immunosuppressive drugs or had been without treatment for at least 60-days at the moment of serum collection tended to have higher total IgE levels as compared to PF patients under treatment (Mann-Whitney test: $P=0.095)$ (Figure 1B).

Anti-SGE IgE was present in the three studied groups, but PF patients exhibited higher IgE titres against A. aegypti and N. neivai SGEs as compared to PFR and HC $(P<0.001)$. Regarding anti-S. nigrimanum SGE IgE, PF patients had higher titres than PFR $(P<0.001)$, but similar titres to HC $(P=0.219)$ (Fig 1C). In the three groups, total IgE levels strongly correlated with IgE antibodies against SGEs from A. aegypti, N. neivai, and S. nigrimanum (Spearman test: $\mathrm{r}=0.848 ; \mathrm{r}=0.852$ and $\mathrm{r}=0.740$, respectively, $P<0.001$ for all) 
(Fig 2A). In PF patients, anti-N. neivai SGE IgE titres were higher as compared to anti-A. aegypti and anti-S. nigrimanum SGE IgE titres ( $P<0.001$ for both) (data not shown).

IgG (data extracted from Vernal et al. [1]) and IgE autoantibody levels against SGEs from $N$. neivai and $S$. nigrimanum ( $\mathrm{r}=0.438, P=0.015$ and $\mathrm{r}=0.419, P=0.021$, respectively), but not against SGE from $A$. aegypti, correlated positively in PF patients. Anti-SGE IgG and IgE did not correlate significantly in PFR and HC for any of the studied SGEs (data not shown).

In PF patients, anti-A. aegypti and anti-S. nigrimanum SGE IgE did not correlate with anti-Dsg1 titres, but anti-N. neivai SGE IgE and anti-Dsg1 IgG titres presented a slightly positive correlation in PF patients $(\mathrm{r}=0.327 ; P=0.077)$ (Fig 2B). Total IgE levels did not correlate with anti-Dsg1 IgG in PF patients ( $\mathrm{r}=-0.256 ; P=0.179)$ (data not shown).

High IgE production has been traditionally linked to intestinal parasitic helminth infestations related to allergic type-1 hypersensitivity reactions [6]. High IgE values in PF patients suggested that $\operatorname{IgE}$ production was due to another hypersensitivity response because PF patients assisted at our service are usually treated with antiparasitic drugs before immunosuppressant therapeutics is initiated, and no atopy signs were detected in these patients.

We found a positive correlation between $\operatorname{IgG}$ and $\operatorname{IgE}$ antibodies against SGEs from S. nigrimanum and N. neivai, but not against SGE from A. aegypti, which supported that PF patients presented a hypersensitivity immune response to the biting flies. Patients had reported the presence of biting flies in their living areas [2]. Although we have not demonstrated a cause-effect relationship between biting flies and PF triggering, we have reported a case of pemphigus vulgaris following myriads of Simulium sp. bites [7]. 
$\operatorname{IgE}$ and IgG responses usually correlate significantly [8]. Even though we were not able to assess anti-Dsg1 IgE, we could expect that anti-Dsg1 IgE and IgG titres correlate positively, as reported previously by Diaz et al. in a Brazilian PF population [4].

Recently, $\operatorname{IgE}$ has also been linked to autoimmune diseases: $\operatorname{IgE}$ antinuclear antibodies have been detected in patients with rheumatic arthritis, systemic lupus, and even bullous pemphigoid [9]. In contrast to IgG, IgE generally has much higher cross-reactivity, which is mainly explained by recognition of carbohydrate-containing epitopes; however, its involvement in self-antigen recognition remains unclear [9].

In conclusion, high total $\operatorname{IgE}$ levels correlate with $\operatorname{IgE}$ antibodies against $A$. aegypti, $N$. neivai, and S. nigrimanum SGEs, reinforcing a hypersensitivity immune response in PF patients. Therefore, successive insect bites - specially sand fly bites - may act as a repetitive antigenic stimulus for individuals living in $\mathrm{PF}$ endemic regions and as a triggering and maintenance environmental autoimmunity factor in individuals that carry susceptibility alleles for PF [1]. 


\section{Acknowledgements.}

The authors thank Prof. Karla Arruda, for allowing us to use laboratory facilities and technical equipment to determine $\operatorname{IgE}$, and the clinical staff of the outpatient autoimmune dermatoses clinic of the Dermatology Division of the University Hospital of Ribeirão Preto Medical School, University of São Paulo, Brazil.

\section{Fundings.}

This project was supported by FAPESP (Fundação de Apoio à Pesquisa do Estado de São Paulo \#2010/51729-2) and NAP-MOBIARVE (Núcleo de Pesquisa em Moléculas

Bioativas de Artrópodes Vetores \#12.1.17661.1.7). S. Vernal received a $\mathrm{PhD}$ scholarship from CAPES (Coordenação de Aperfeiçoamento de Pessoal de Nível Superior). M. Pepinelli was a CNPq-CSF (Conselho Nacional de Desenvolvimento Científico e Tecnológico - Ciências Sem Fronteiras) fellow (\#205742/2014-9).

\section{Author contributions.}

Conceptualization, methodology: SV, AMR. Formal analysis: SV, MPe, WO, TG, MPi, AS, AMR. Funding acquisition: AS, AMR. Investigation, resources: SV, MP, WO, TG, MP, AS, AMR. Supervision: MPe, MPi, AS, AMR. Writing and reviewing manuscript: SV, MPe, WO, TG, MPi, AS, AMR.

\section{Conflict of interested.}

All authors declared: none 


\title{
Ethical approval.
}

\author{
All procedures performed in studies involving human participants were in \\ accordance with the ethical standards of the research committee University Hospital of the \\ Ribeirão Preto Medical School of the University of São Paulo and with the 1964 Helsinki \\ declaration and its later amendments or comparable ethical standards.
}

\section{Informed consent.}

Informed consent was obtained from all individual participants included in the study. 


\section{References}

[1] Vernal S, Pepinelli M, Casanova C, Goulart TM, Kim O, De Paula NA, Pinto MC, Sá-Nunes A, Roselino AM. Insights into the epidemiological link between biting flies and pemphigus foliaceus in southeastern Brazil. Acta Trop. 2017;176:455-62.

[2] Lombardi C, Borges PC, Chaul A, Sampaio SA, Rivitti EA, Friedman H, Martins CR, Sanches Junior JA, Cunha PR, Hoffman RG, et al. Environmental risk factors in endemic pemphigus foliaceus (Fogo selvagem). "The Cooperative Group on Fogo Selvagem Research". J Invest Dermatol. 1992;98(6):847-50.

[3] Qian Y, Jeong JS, Maldonado M, Valenzuela JG, Gomes R, Teixeira C, Evangelista F, Qaqish B, Aoki V, Hans G Jr, Rivitti EA, Eaton D, Diaz LA. Cutting Edge: Brazilian pemphigus foliaceus anti-desmoglein 1 autoantibodies cross-react with sand fly salivary LJM11 antigen. J Immunol. 2012;189(4):1535-39.

[4] Qian Y, Prisayanh P, Andraca E, Qaqish B, Aoki V, Hans-Filhio G, Rivitti EA, Diaz LA. IgE, IgM, and IgG4 anti-desmoglein 1 autoantibody profile in endemic pemphigus foliaceus (fogo selvagem). J Invest Dermatol. 2011;131(4):985-87.

[5] Qian Y, Jeong JS, Abdeladhim M, Valenzuela JG, Aoki V, Hans-Filhio G, Rivitti EA, Diaz LA. IgE anti-LJM11 sand fly salivary antigen may herald the onset of fogo selvagem in endemic Brazilian regions. J Invest Dermatol. 2015;135(3):91315.

[6] Tay TR, Bosco J, Aumann H, O'Hehir R, Hew M. Elevated total serum immunoglobulin E (>1000 IU/mL): implications? Intern Med J. 2016;46(7):846-49.

[7] Wambier CG, Struecker TA, Durski LN, de Araujo AG, Wambier SPF, Cappel MA, Vernal S, Roselino AM. Image Gallery: A case of pemphigus vulgaris following Simulium spp. (Diptera) bites. Br J Dermatol. 2017;176(5):e100. 
[8] Berrens L, Homedes IB. Relationship between IgE and IgG antibodies in type I allergy. Allerg Immunol (Leipz). 1991;37(3-4):131-37.

[9] Maurer M, Altrichter S, Schmetzer O, Scheffel J, Church MK, Metz M. Immunoglobulin E-Mediated Autoimmunity. Front Immunol. 2018;9:689. 


\section{Figure legends}

Figure 1. A - Total IgE determination (kU/L) ImmunoCAP ${ }^{\mathrm{TM}}$ Total $\operatorname{IgE}$ in the studied groups. Cut-off = $100 \mathrm{kU} / \mathrm{L} . \mathbf{B}-$ Total IgE determination $(\mathrm{kU} / \mathrm{L})$ ImmunoCAP $^{\mathrm{TM}}$ Total IgE in the PF group: without versus under treatment. Cut-off $=100 \mathrm{kU} / \mathrm{L}$. $\mathbf{C}-$ Anti-IgE ELISA (OD - optical density) against salivary gland extracts (SGEs) from Aedes aegypti, Nyssomyia neivai, and Simulium nigrimanum in the studied groups.

$\mathrm{PF}=$ pemphigus foliaceus. $* *=P<0.05, * * *=P<0.001$

Figure 2. A - Correlation between IgE antibodies against SGE (OD) and total IgE among three groups. B - Correlation between IgE antibodies against salivary gland extract (OD optical density) and anti-Desmoglein $1 \mathrm{IgG}(\mathrm{U} / \mathrm{mL})$ in the PF group. IgE antibodies (OD) against salivary gland extracts (SGEs) from Aedes aegypti (A), Nyssomyia neivai (B), and Simulium nigrimanum $(\mathrm{C})$ 


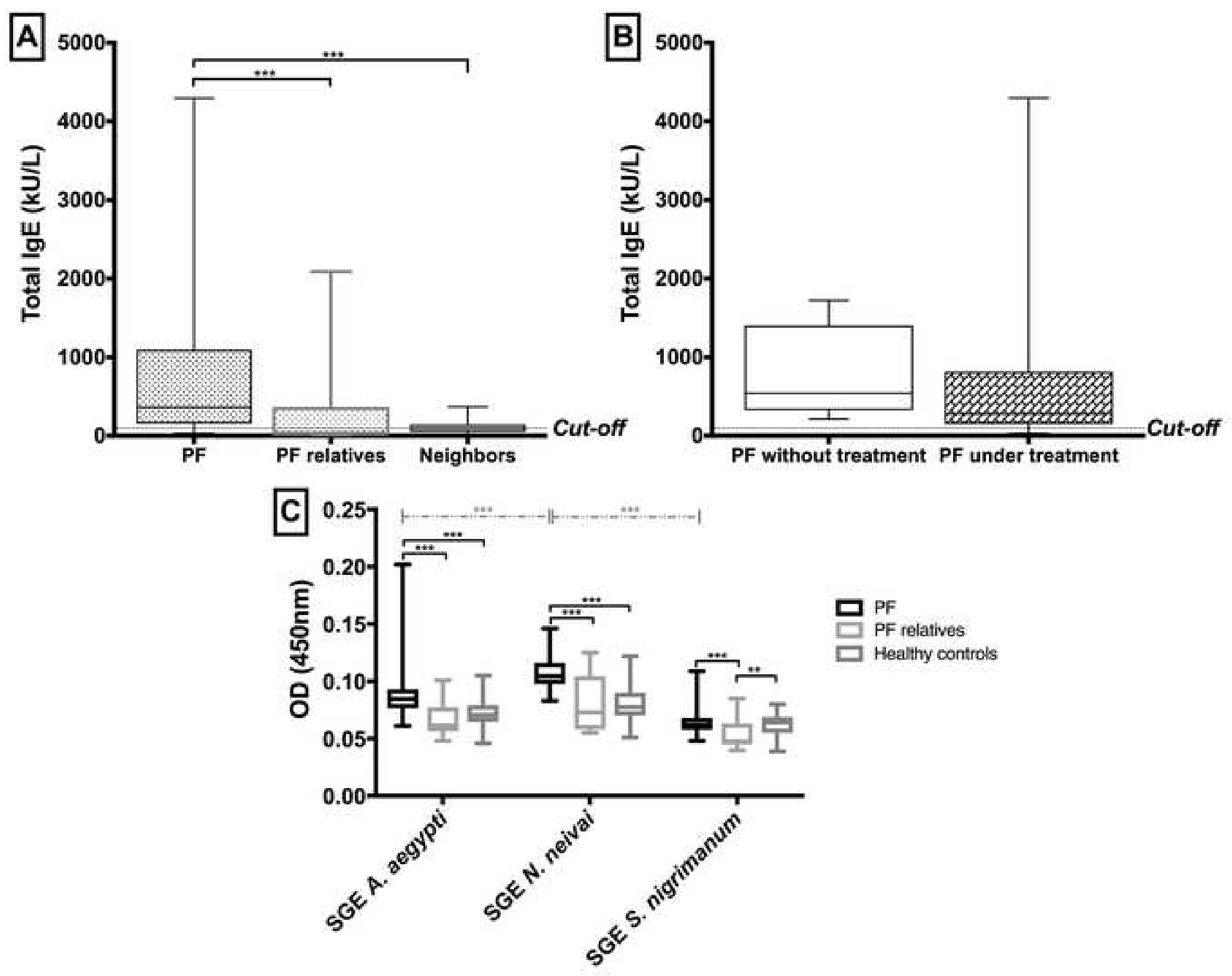

$\square$ PF

PF relatives

Healthy controls 

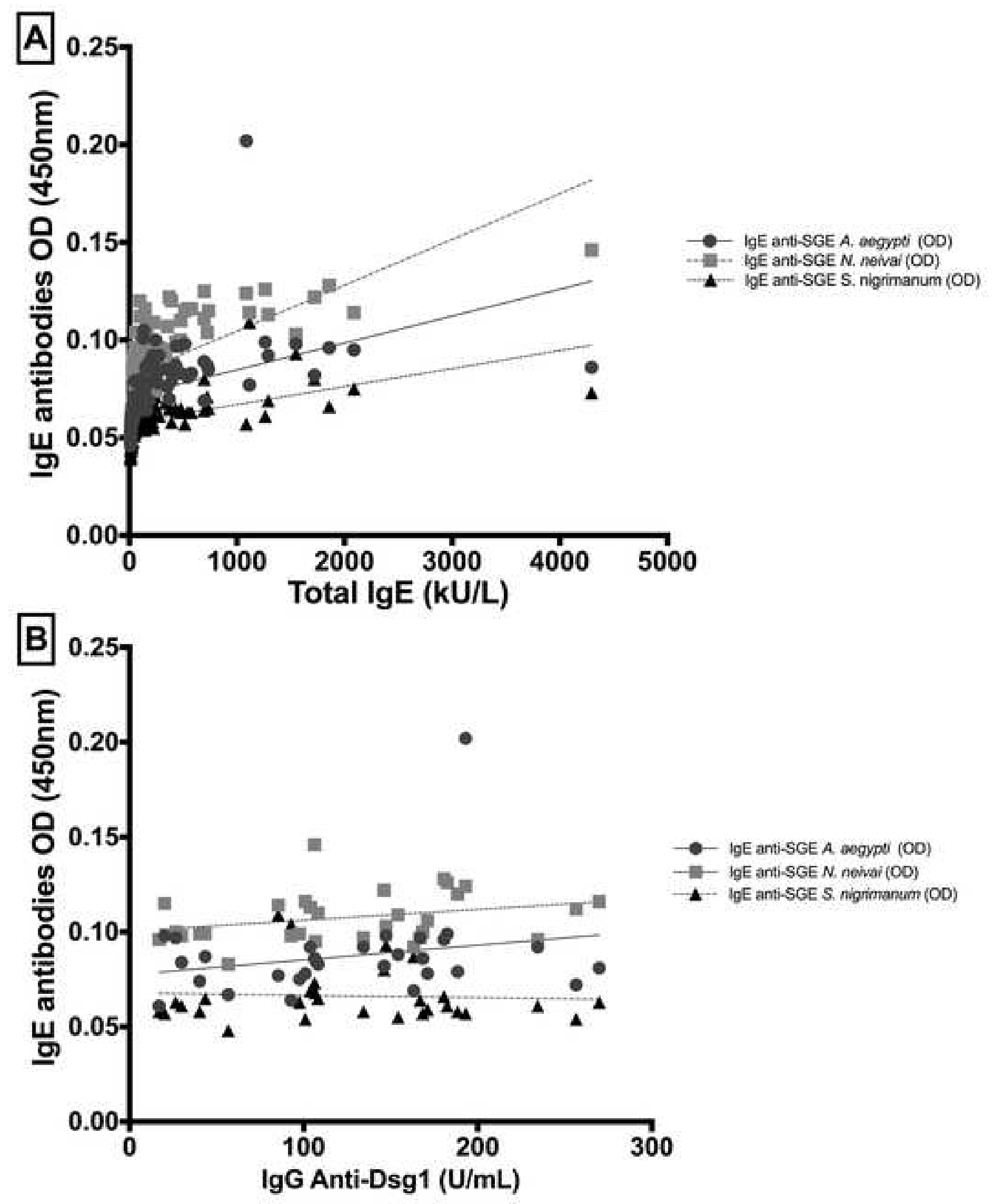
5.2.2 Patients with pemphigus foliaceus recognized several salivary proteins from biting flies in Southeastern Brazil: anew hypothesis to explain its endemicity. Jornal: Transactions of the Royal Society of Tropical Medicine and Hygiene. Fator de impacto: 2,065. Formato: Concise Communication.

Exposure to salivary proteins of biting flies may be related to Brazilian pemphigus foliaceus etiopathogenesis in genetically susceptible individuals

S. Vernal; M. Pepinelli; W. Oliveira; T. Goulart; M. Pinto; A.M. Roselino 
Transactions of the Royal Society of Tropical Medicine and Hygiene - Concise Communication

Patients with pemphigus foliaceus recognized several salivary proteins from biting flies in Southeastern Brazil: a new hypothesis to explain its endemicity

Running title: Biting flies and pemphigus foliaceus

Vernal S.1; Pepinelli M.2,3; Oliveira W.4; Goulart T.4; Pinto M.4; Roselino A.M. ${ }^{1}$

1Division of Dermatology, Department of Clinical Medicine, Ribeirão Preto Medical School, University of São Paulo, Ribeirão Preto, São Paulo, Brazil

${ }^{2}$ Department of Natural History, Royal Ontario Museum, Toronto, Ontario, Canada

${ }^{3}$ Department of Ecology and Evolutionary Biology, University of Toronto, Toronto, Ontario, Canada

4Department of Parasitology, São Paulo State University Julio de Mesquita Filho, Araraquara, São Paulo, Brazil

\section{Corresponding author}

Ana Maria Roselino, M.D. University Hospital, Ribeirão Preto Medical School, University of São Paulo. Av. Bandeirantes 3900, Monte Alegre, Ribeirão Preto, São Paulo - 14040-900). Phone number: +55.16 .36022715 .

Fax number: +55.16.36023315. E-mail: amfrosel@fmrp.usp.br 


\section{Background}

Pemphigus foliaceus (PF) is an autoimmune bullous disease immunologically characterized by the production of autoantibodies against desmoglein (Dsg) 1. PF is subdivided into classic sporadic worldwide Cazenave's pemphigus and endemic pemphigus (known in Brazil as Fogo Selvagem). Both PF forms share the same immune-pathogenesis, but differ in their epidemiological and distribution patterns. ${ }^{1}$ Endemic PF etiopathogenesis remains unclear; notwithstanding, a combination of genetic and environmental factors has been implicated in its triggering. ${ }^{2,3}$

Several environmental factors have been related to PF including virus infection, contaminated soil and/or water, agricultural additives, parasitic infections, and insects biting',4-7 In the forties, Vieira8 described the geographical behavior of PF in São Paulo state, southeastern Brazil, showing several well-defined foci especially near to rivers and mainly in the northeastern region. Vieira also pointed out an epidemiological link between Simulium nigrimanum (Macquart, 1838) and the endemicity of PF. Later Diaz et al. confirmed Simulium sp. bites have been considered a risk factor for the development of PF (odds ratio=4.7) in an Amerindian reserve in Mato Grosso do Sul State, Brazil. ${ }^{9}$

Despite S. nigrimanum was for many years the main implicated insect on PF etiopathogenesis, in the last two decades sand flies species arisen as a new environmental factor triggering PF autoimmunity in genetic susceptible individuals, suggesting that some of their salivary glands components may lead to a mimetic antigenicity cross-reacting with Dsg1. 10-13 In 2001, Roselino et al. reported the first approach to a sand fly-PF link, showing higher titres of $\lg G$ antibodies against maxadilan - one of the most immunogenic salivary proteins described in Lutzomyia longipalpis (Lutz and Neiva, 1912) - in PF patients compared to healthy controls (HC) living in northeastern São Paulo State (NSSP). ${ }^{10}$ In 2012, Diaz et al. evidenced that LJM11 - another highly immunogenic protein from Lu. longipalpis - had similarity with Dsg1 peptide. ${ }^{11}$ In the same way, Zaraa et al. 
reported the recognition of five salivary proteins of $12,15,21,30$ and $36 \mathrm{kDa}$ from the sand fly Phlebotomus papatasi (Scopoli, 1786) by the sera of PF Tunisian patients where PF is also endemic. ${ }^{13}$

Nyssomyia intermedia (Lutz \& Neiva, 1912) and Nyssomyia neivai (Pinto, 1926) are the main vectors of tegumentary leishmaniasis (TL) in São Paulo State. However, only N. neivai has been identified in research collections done systematically in NSSP. ${ }^{14}$ Lu. longipalpis has been documented in São Paulo state after the sixties, at least forty-years after the first publication of PF geographical foci in this region, and so far it has not been related to PF clusters. ${ }^{2,15}$

Focusing in southeastern Brazil PF endemic foci, PF patients and their relatives (PFR) presented higher titres of IgG antibodies against salivary gland extract (SGE) of S. nigrimanum and N. neivai, but not against the mosquito Aedes aegypti when compared to healthy controls ( $\mathrm{HC})$ living in that region. ${ }^{2}$ Moreover, IgG antibodies against SGE from $S$. nigrimanum and $N$. neivai, but not from $A$. aegypti, correlated with $\lg$ G anti-Dsg1 autoantibodies in PF patients. ${ }^{2}$

Considering these results, the aimed of this study is to reveal further SGE recognition using immunoblotting (IB) assay, and to describe the demographic and clinical profile of those patients with the higher titres against $S$. nigrimanum and N. neivai SGEs in NSSP. Following our results and using the compiled data available in the literature, we proposed an adjustment in flies-PF etiopathogenic link hypothesis. 


\section{Methods}

\section{Study Population}

Patients were assisted at the University Hospital of Ribeirão Preto Medical School, University of São Paulo, Brazil, which is the main reference institution for the diagnosis and treatment of pemphigus in NSSP. The clinical diagnosis of PF was confirmed by acantholytic bullae on the histopathological examination, positive lgG fluorescence around keratinocytes in skin samples, and presence of serum autoantibodies against Dsg1 using commercial ELISA (MBL, Nagoya, Japan).

As we reported previously ${ }^{2}$ we tested 30 PF patients' serum samples randomly selected from the Pemphigus Bank, Laboratory of Dermatology, Ribeirão Preto Medical School, with active clinical disease at the time of serum collection (presence of Nikolsky's sign). Sera were tested in ELISAs coated with SGE from $A$. aegypti, N. neivai and S. nigrimanum. The control groups consisted of sera randomly selected from 30 PFR and $30 \mathrm{HC}$ living in the PF endemic region and without any autoimmune diseases.

Now, we selected sera samples presenting the highest ELISA IgG titres anti-S. nigrimanum and N. neivai SGEs results for immunoblotting (IB) assays as follow:

- Twenty-five serum samples with highest anti-SGE titres from S. nigrimanum including: 11 PF patients and 14 controls (nine PFR and five HC). Demographic and clinical data of PF, PFR and HC are available in Supplementary Table 1S, 2 S and 3 S respectively.

- Twenty serum samples with highest anti-SGE titres from N. neivai, including 9 PF patients and 11 controls (eight PFR and three HC). Besides, considering N. neivai as the main vector of TL in NSSP, we tested three serum samples from TL patients to compare the recognition patterns on IB assay. Demographic and clinical data of PF, PFR and HC are available in Supplementary Table 4S, 5 S and 6 S respectively. 
Patients were subscribed as $1 \mathrm{Sn}$ to $25 \mathrm{Sn}$ from the highest value and progressive decreased titres on ELISA against SGE from S. nigrimanum, and $1 \mathrm{Ny}$ to $20 \mathrm{Ny}$ from the highest value and progressive decreased titres on ELISA against SGE from N. neivai.

\section{Insect samplings, salivary glands extract and SDS-PAGE}

Samples collections, salivary glands dissection and extraction, and SDS-PAGE characterization of the extractions were performed as previously described. ${ }^{2}$

\section{Immunoblotting assay}

Immunoblotting was carried out by transferring the SGE protein $(5 \mu \mathrm{g} /$ well $[2,5 \mu \mathrm{g} / \mu \mathrm{L}])$ to a $0.45-\mathrm{nm}$ nitrocellulose membrane (Biorad®, USA), followed by blocking in 3\% skimmed milk (BioRad®, USA) at room temperature (RT) for $1 \mathrm{~h}$. Strips were incubated with serum samples diluted 1:20 in TBS containing $3 \%$ skimmed milk at $4{ }^{\circ} \mathrm{C}$, overnight. After washing with Tween 20-TBS for $5 \mathrm{~min}$ three times and with TBS for 5 min once, the strips were incubated in HRP-anti-human IgG (BioRad®, USA) 1:2000 at RT for 2h. After four more washings, the reaction was developed by adding Color-Plus HRP (BioRad®, USA).

\section{Ethics}

The study complies with the 1975 Declaration of Helsinki, as revised in 2013 (Declaration of Helsinki World Medical Association, 2014), and was approved by the Local Committee for Ethics in Human Research $\# 12248 / 2010$. 
Results

Immunoblot using Simulium nigrimanum SGE

PF and controls mainly recognized a $\sim 250 \mathrm{kDa}$ peptide from $S$. nigrimanum SGE (blue square). Recognition of $\sim 75 \mathrm{kDa}$ peptide (red square) was more clearly defined in PF patients (7/11) and PFR (5/9), and weaker recognized by $\mathrm{HC}(2 / 5)$. Salivary peptides smaller than $60 \mathrm{kDa}$ were mainly recognized by PF (8/11) and some PFR (2/5), but not in $\mathrm{HC}(0 / 5)$ (green square) (Figure 1A).

\section{Immunoblot using Nyssomyia neivai SGE}

PF and controls mainly recognized peptides between $50 \mathrm{kDa}$ and $75 \mathrm{kDa}$ (red square) from N. neivai SGE. Recognition of peptides between $5 \mathrm{kDa}$ and $10 \mathrm{kDa}$ (green square) was more clearly defined in PF (6/9) patients and PFR (4/8), and weaker by HC (1/3). Interestedly, the three TL patients shared similar recognition patterns, showing well-defined peptides between $50 \mathrm{kDa}$ and $75 \mathrm{kDA}$ (red square) and between $5 \mathrm{kDa}$ to $10 \mathrm{kDa}$ (green square) (Figure 1B).

\section{Discussion}

Despite the decreased PF diagnosis in NSSP, especially at seventies and eighties, new cases of PF have been diagnosed over the last decades, with maintenance of its prevalence. ${ }^{4}$ The expansion of urban boundaries, migrations movements to Brazil and forest invasion by sugar cane agribusiness and coffee plantations presents a new stage of cohabitation with local fauna previously confined outside the cities, especially relate to the greater exposure to flies' bites, leading to diseases previously restricted to rural activities (e.g. leishmaniasis, a disease 
transmitted by a sandfly bite). ${ }^{16}$ It is in this scenario that geographical foci of PF cases began to appear, especially surrounding watersheds, leading to suspect that a local setting may be involved in PF etiopathogenesis.

Regarding our previously epidemiological link confirmation between biting flies and geographical foci of PF cases in NSPS, ${ }^{2}$ we now detail the humoral response of these PF patients and endemic HC to SGEs from two widely distributed biting flies' using IB assays. We complemented our results with a demographic and clinical description of each patient analyzed. Interestedly, most of Brazilian PF data came from studies in Amerindians population, a very homogenous and isolated sample; ${ }^{17-19}$ here we study a mixed population sample including Caucasian, Black and Mullatos, but any Amerindian patient, expanding our understanding of susceptibly and protection ethnicity factors involved in PF etiopathogenesis.

Our results invigorate that flies salivary proteins seem to contribute to PF etiopathogenesis in genetically susceptible individuals. HLA susceptibility/protection alleles seems to decide if individuals with continuous exposure to flies' bites may induce an autoimmunity trigger to $\lg G$ pathogenic autoantibodies against Dsg1. Selfantigen reaction could be explained by: (a) salivary peptides introduced into the host's skin while acquiring a blood meal triggering a antigen cross-reaction with Dsg1; (b) local skin inflammatory reactions due to flies' bites may produce an anomalous Dsg1 exposure (damaged) leading to an aberrant Dsg1 presentation to immune cells.

In last decades, this first hypothesis has gained scientific support by the description of a sandfly a salivary protein - LJM11 - which cross-reacted Dsg1 autoantibodies. ${ }^{11}$ Furthermore, it has been proposed that anti-LJM11 IgE could underlie PF triggering in some Amerindian populations living in PF endemic regions. ${ }^{12}$ Nevertheless, three main points plays against this proposal: (1) LJM11 has been only described in New World sandflies, specifically L. longipalpis, then it can not explain PF endemic foci in the Old World regions (ex. Tunisia); ;3,20 (2) Even considering the New World, L. longipalpis is not widely distributed in some Brazilian PF endemic foci as we recently confirmed;2,15 (3) Others sandflies distributed in those PF endemic regions do not exhibited LJM11 
peptide in their sialotranscriptomes (ex. N. neivai, P. papatasi). ${ }^{21}$ Even more, biologically is implausible that just one peptide of one insect may explain the endemicity of PF worldwide (Figure 2).

Thus, the second hypothesis emerges as a more plausible explanation for PF endemicity in some worlds regions. Despite each local flies evidences a specific high immunogenic salivary peptides, during the bite the fly also introduce other various pharmacological components of its saliva (vasodilatation, platelet anti-aggregation, anesthetic, etc.) modulating the host's immune system. ${ }^{22}$ Chronic exposure to biting flies leads to a hypersensitivity type-1 response including $\lg G$ and $\lg E$ antibodies recruitment to the bite-site. ${ }^{23}$ Population settled around watersheds is daily bitted by endemic flies. ${ }^{9}$ The continuous submission to local immunogenic peptides into the skin plus the local allergic response by the host may induce to an immunocompromised district including an abnormal Dsg1 exposure and subsequently an irregular dendritic cells presentation in genetically susceptible individuals, losing the immune-tolerance to Dsg1. This hypothesis is supported by: (1) PF patients recognized salivary gland extracts from their respectively endemic region (ex. PF Tunisian patients evidenced antibodies against $P$. papatasi; (2)2,11,13 Brazilian Amerindian populations exhibited antibodies and Dsg1 cross-reaction with more than one salivary protein of L. longipalpis (LJM11 and LJM17);11,24 (3) Elevated total IgE antibodies have been describe in PF patients, with a hypersensitive type-1 response to biting flies and IgE anti-Dsg1 antibodies;12,23,25 and (4) vector-borne parasitic infections (ex. Leishmaniasis and Onchocerciasis) also demonstrated circulation of $\operatorname{lgG}$ anti-Dsg1,7,26 (5) Healthy controls living in the endemic regions also evidenced anti-Dsg1 lgG circulated antibodies;27-30 and (6) others cadherin family proteins as Dsg2 and/or Dsc1-3.30 Thereby, our findings reinforce that more than one salivary proteins of biting flies is involved in PF etiopathogenesis, and not from only a single flies species.

Maxadilan is a $7-\mathrm{kDa}$ peptide present in L. Iongipalpis salivary gland; however, a Maxadilan-simile has also been describe in $N$. neivai sialome. ${ }^{31}$ Maxadilan was the first molecule to be identified in the sandfly saliva and it is recognized for its powerful vasodilator effect. ${ }^{32}$ Inoculation of Max in experimental animals exacerbates 
Leishmania infection to the same degree as the whole salivary gland. ${ }^{33}$ JAV08462.1 (putative Maxadilan N. neivai) is closely related to Maxadilan peptide, suggestion that pharmacological properties, including vasodilation, may be conserved in N. neivai (GenBank NCBI accessed). Description of anti-Maxadilan antibodies in the TL patients and healthy controls living in Southeastern Brazil confirms previous exposure to $N$. neivai sandfly bites and suggests natural and chronic exposure to this vector. ${ }^{31}$ Here we used three TL patients as controls in IB assays against $N$. neivai SGE. Interestedly, PF patients and PF relatives showed a very similar IB recognition patters to these three $\mathrm{TL}$ patients, leaving in evidence well-defined bands between $50 \mathrm{kDa}$ and $75 \mathrm{kDA}$ and $\sim 7 \mathrm{kDA}$. Our findings confirmed the results by Roselino et al. in 2001, when it was proposed the participation of sandflies biting, specifically the most immunogenic peptides as Maxadilan, might play a role in PF etiopathogenesis. ${ }^{10}$

Although S. nigrimanum and N. neivai are two species far way in evolution time line, they converge in Diptera (Nematocera) family. ${ }^{34}$ IgG antibodies from these two insects positively correlated in PF patients, ${ }^{2}$ hypothesizing that their SGE could have some salivary proteins with similar antigen and/or pharmacological effects, modulating alike the host's immune response. In the nineties, Amerindians PF patients were questioned about insects as risk environmental factor; curiously, there were not description of sandflies but $S$. nigrimanum and other blackflies (ex. Simulium pertinax) were described. ${ }^{35}$ Flies from the Diptera family (true flies) are widely spread worldwide, ${ }^{36}$ but they especially prevalent in tropical conditions were most of the PF foci have been observed, including north region of South America (Venezuela, Colombia, Peru, Paraguay and Brazil) and Africa (Tunisia).2,13,15,36-38 The Diptera larvae can be herbivores, scavengers, decomposers, predators or parasites, with the consumption of decaying organic matter being one of the most prevalent feeding behaviors; 39 thus, its population density is concentrated near to watersheds as PF cases also grouped.

Endemic PF regions also shared some interested geo-demographical features. Additionally to environmental conditions, the European immigrants introduced a genetic patterns and mixed populations previously unexposed to tropical local fauna. The largest influx of European immigrants to Brazil occurred in the 
late 19th and early 20th centuries. ${ }^{40}$ According to the Memorial do Imigrante statistics data, Brazil attracted nearly 5 million immigrants between 1870 and $1953 .{ }^{41}$ These immigrants were divided in two groups: a part of them was sent to Southern Brazil to work as small farmers; however, the biggest part of the immigrants was sent to Southeast Brazil to work in the coffee plantations. ${ }^{40,41}$ It is exactly in this geographical region where the first cases and endemic foci of PF were described at the begging of the ninth century. Similar situation was noted in Tunisia: from the late 19th century to after World War II, Tunisia was home to large populations of French and Italians, ${ }^{42}$ a population virgin to local flies continuous bite exposure.

\section{Conclusion}

Brazil represents a perfect scenario to the autoimmunity diseases' triangle: genetics, environment and inflammation. Genetic profile (HLA I and II) has been well identified in Southeastern Brazilian population, exhibited specific susceptibility alleles to PF. In this same population, we already confirm the epidemiological link between PF clusters and biting flies geographical distribution. In this report we now confirmed the genetic-environmental link in patients genetically susceptible exposed to biting flies (black- and sandflies). Moreover, we proposed a more plausible explanation for PF endemicity in some worlds regions, which included a continuous inflammation by biting flies followed by an immunological local unbalance and losing self-antigen intolerance to Dsg1. Further studies are necessary to confirm our hypothesis. 


\section{Acknowledgements}

The authors are very grateful to the clinical staff that assisted pemphigus outpatients at the University Hospital of the Ribeirão Preto Medical School, University of São Paulo, Brazil.

\section{Conflict of interest}

The authors state that they do not have any conflict of interest, and that they agree with the publication.

\section{Financial support}

This study was funded by FAPESP (Fundação de Amparo à Pesquisa do Estado de São Paulo, Process \# 2010/51729-2). SV received doctoral scholarships from CAPES (Coordenação de Aperfeiçoamento de Pessoal de Nivel Superior). Funding/Sponsor was not involved in design and conduct of the study, collection, management, analysis and interpretation of data, preparation, review, or approval of the manuscript; and/or decision to submit the manuscript for publication. 


\section{References}

1. Buonavoglia A, Leone P, Dammacco R, et al. Pemphigus and mucous membrane pemphigoid: An update from diagnosis to therapy. Autoimmun Rev. 2019;18(4):349-358.

2. Vernal S, Pepinelli M, Casanova C, et al. Insights into the epidemiological link between biting flies and pemphigus foliaceus in southeastern Brazil. Acta Trop. 2017;176:455-462.

3. Brochado MJ, Nascimento DF, Campos W, Deghaide NH, Donadi EA, Roselino AM. Differential HLA class I and class II associations in pemphigus foliaceus and pemphigus vulgaris patients from a prevalent Southeastern Brazilian region. J Autoimmun. 2016.

4. Celere BS, Vernal S, La Serra L, et al. Spatial Distribution of Pemphigus Occurrence over Five Decades in Southeastern Brazil. Am J Trop Med Hyg. 2017;97(6):1737-1745.

5. Machado ARDS, La Serra L, Turatti A, Machado AM, Roselino AM. Herpes simplex virus 1 and cytomegalovirus are associated with pemphigus vulgaris but not with pemphigus foliaceus disease. Exp Dermatol. 2017;26(10):966-968.

6. La Serra L, Salathiel AM, Trevilato TMB, et al. Trace element profile in pemphigus foliaceus and in pemphigus vulgaris patients from Southeastern Brazil. J Trace Elem Med Biol. 2019;51:31-35.

7. Walsh P, Brochado MJF, Vernal S, et al. Relationship between pemphigus and American tegumentary leishmaniasis: insights from serological and genetic profiles. Trans $R$ Soc Trop Med Hyg. 2017;111(8):345-353.

8. Vieira J. Pemphigus foliaceus (fogo selvagem) - an endemic disease in the state of Sao Paulo (Brazil). Arch Dermatol Syphilol. 1940;41:858-863. 
9. Lombardi C, Borges PC, Chaul A, et al. Environmental risk factors in endemic pemphigus foliaceus (Fogo selvagem). "The Cooperative Group on Fogo Selvagem Research". J Invest Dermatol. 1992;98(6):847850.

10. Roselino AM, Figueiredo JFC, Kounga K, Reddy V, Lerner EA. Serum IgG from pemphigus foliaceus patients reacts against maxadilan. J Investig Dermatol. 2001;117:460.

11. Qian $\mathrm{Y}$, Jeong JS, Maldonado M, et al. Cutting Edge: Brazilian pemphigus foliaceus anti-desmoglein 1 autoantibodies cross-react with sand fly salivary LJM11 antigen. J Immunol. 2012;189(4):1535-1539.

12. Qian $\mathrm{Y}$, Jeong JS, Abdeladhim M, et al. IgE anti-LJM11 sand fly salivary antigen may herald the onset of fogo selvagem in endemic Brazilian regions. J Invest Dermatol. 2015;135(3):913-915.

13. Zaraa I, Boussoffara T, Ben Ahmed M, et al. Exposure to Phlebotomus papatasi and/or Leishmania major: possible etiologic link to Tunisian pemphigus. J Invest Dermatol. 2012;132(2):479-482.

14. Andrade Filho JD, Galati EA, Falcão AL. Nyssomyia intermedia (Lutz \& Neiva, 1912) and Nyssomyia neivai (Pinto, 1926) (Diptera: Psychodidae: Phlebotominae) geographical distribution and epidemiological importance. Mem Inst Oswaldo Cruz. 2007;102(4):481-487.

15. Casanova C, Colla-Jacques FE, Hamilton JG, Brazil RP, Shaw JJ. Distribution of Lutzomyia longipalpis chemotype populations in São Paulo state, Brazil. PLoS Negl Trop Dis. 2015;9(3):e0003620.

16. Tolezano JE. Ecoepidemiological aspects of American cutaneous leishmaniasis in the state of São Paulo, Brazil. Mem Inst Oswaldo Cruz. 1994;89(3):427-434.

17. Moraes ME, Fernandez-Vina M, Lazaro A, et al. An epitope in the third hypervariable region of the DRB1 gene is involved in the susceptibility to endemic pemphigus foliaceus (fogo selvagem) in three different Brazilian populations. Tissue Antigens. 1997;49(1):35-40.

18. Cerna M, Fernandez-Viña M, Friedman H, et al. Genetic markers for susceptibility to endemic Brazilian pemphigus foliaceus (Fogo Selvagem) in Xavante Indians. Tissue Antigens. 1993;42(3):138-140. 
19. Pavoni DP, Roxo VM, Marquart Filho A, Petzl-Erler ML. Dissecting the associations of endemic pemphigus foliaceus (Fogo Selvagem) with HLA-DRB1 alleles and genotypes. Genes Immun. 2003;4(2):110-116.

20. Anderson JM, Oliveira F, Kamhawi S, et al. Comparative salivary gland transcriptomics of sandfly vectors of visceral leishmaniasis. BMC Genomics. 2006;7:52.

21. Abdeladhim M, Jochim RC, Ben Ahmed M, et al. Updating the salivary gland transcriptome of Phlebotomus papatasi (Tunisian strain): the search for sand fly-secreted immunogenic proteins for humans. PLoS One. 2012;7(11):e47347.

22. Abdeladhim M, Kamhawi S, Valenzuela JG. What's behind a sand fly bite? The profound effect of sand fly saliva on host hemostasis, inflammation and immunity. Infect Genet Evol. 2014;28:691-703.

23. Qian Y, Culton DA, Jeong JS, Trupiano N, Valenzuela JG, Diaz LA. Non-infectious environmental antigens as a trigger for the initiation of an autoimmune skin disease. Autoimmun Rev. 2016.

24. Diaz LA, Prisayanh P, Qaquish B, et al. The sand fly Lutzomyia longipalpis LJM17 protein induces crossreactive antibodies against desmoglein-1 in Fogo Selvagem. Journal of Investigative Dermatology. 2019;139(5).

25. Qian $\mathrm{Y}$, Prisayanh $\mathrm{P}$, Andraca $\mathrm{E}$, et al. $\lg \mathrm{E}$, $\lg \mathrm{M}$, and $\lg \mathrm{G} 4$ anti-desmoglein 1 autoantibody profile in endemic pemphigus foliaceus (fogo selvagem). J Invest Dermatol. 2011;131(4):985-987.

26. Diaz LA, Arteaga LA, Hilario-Vargas J, et al. Anti-desmoglein-1 antibodies in onchocerciasis, leishmaniasis and Chagas disease suggest a possible etiological link to Fogo selvagem. J Invest Dermatol. 2004;123(6):1045-1051.

27. Hans-Filho G, dos Santos V, Katayama JH, et al. An active focus of high prevalence of fogo selvagem on an Amerindian reservation in Brazil. Cooperative Group on Fogo Selvagem Research. J Invest Dermatol. 1996;107(1):68-75 . 
28. Aoki V, Millikan RC, Rivitti EA, et al. Environmental risk factors in endemic pemphigus foliaceus (fogo selvagem). J Investig Dermatol Symp Proc. 2004;9(1):34-40.

29. Flores $\mathrm{G}$, Qian Y, Díaz LA. The enigmatic autoimmune response in endemic pemphigus foliaceus. Actas Dermosifiliogr. 2009;100 Suppl 2:40-48.

30. Flores $\mathrm{G}$, Culton DA, Prisayanh $\mathrm{P}$, et al. IgG autoantibody response against keratinocyte cadherins in endemic pemphigus foliaceus (fogo selvagem). J Invest Dermatol. 2012;132(11):2573-2580.

31. Aires JM, Chociay MF, Nascimento MM, Figueiredo JF, Roselino AM. Maxadilan (MAX) - Salivaly protein of Lutzomyia longipalpis: detection of antibodies anti-MAX in American tegmentar leishmaniasis (ATL), and genetic and protein expression of MAX in Lutzomyia neivai. An Bras Dermatol. 2005;80(Supplemental):S333-S338.

32. Lerner EA, Ribeiro JM, Nelson RJ, Lerner MR. Isolation of maxadilan, a potent vasodilatory peptide from the salivary glands of the sand fly Lutzomyia longipalpis. J Biol Chem. 1991;266(17):11234-11236.

33. Morris RV, Shoemaker CB, David JR, Lanzaro GC, Titus RG. Sandfly maxadilan exacerbates infection with Leishmania major and vaccinating against it protects against L. major infection. J Immunol. 2001;167(9):5226-5230.

34. Ribeiro JM, Mans BJ, Arcà B. An insight into the sialome of blood-feeding Nematocera. Insect Biochem Mol Biol. 2010;40(11):767-784.

35. Eaton DP, Diaz LA, Hans-Filho G, et al. Comparison of black fly species (Diptera: Simuliidae) on an Amerindian reservation with a high prevalence of fogo selvagem to neighboring disease-free sites in the State of Mato Grosso do Sul, Brazil. The Cooperative Group on Fogo Selvagem Research. J Med Entomol. 1998;35(2):120-131.

36. The Catalogue of Life Partnership: BioSystematic Database of World Diptera. Published 2019. Accessed August, 2019. 
37. Abréu-Vélez AM, Roselino AM, Howard MS, Reason IJ. Endemic pemphigus over a century: Part II. N Am J Med Sci. 2010;2(3):114-125.

38. Ortega-Loayza AG, Ramos W, Gutierrez EL, Jimenez G, Rojas I, Galarza C. Endemic pemphigus foliaceus in the Peruvian Amazon. Clin Exp Dermatol. 2013;38(6):594-600.

39. Wiegmann BM, Yeates DK. Diptera. True Flies. Published 2007. Accessed.

40. Clevelario-Junior J. A participação da imigração na formação da população brasileira. Rev Bras Estudos Pop. 1997;14(1/2).

41. Levy MSF. The role of internation migration on the evoluiton of the Brazilian population (1872 to 1972). Rev Saude Pública. 1974;8.

42. De Bel-Air F. Migration profile: Tunisia. Migration Policy Centre. 2016:1-19.

43. Moraes JR, Moraes ME, Fernandez-Vina M, et al. HLA antigens and risk for development of pemphigus foliaceus (fogo selvagem) in endemic areas of Brazil. Immunogenetics. 1991;33(5-6):388-391.

44. Moura RR, Coelho AV, Balbino VeQ, Crovella S, Brandão LA. Meta-analysis of Brazilian genetic admixture and comparison with other Latin America countries. Am J Hum Biol. 2015;27(5):674-680.

45. Pimenta JR, Zuccherato LW, Debes AA, et al. Color and genomic ancestry in Brazilians: a study with forensic microsatellites. Hum Hered. 2006;62(4):190-195. 
Figures' legends

Figure 1. Anti-lgG human Immunoblot assay: A - Twenty-two serum samples selected with the higher titres on ELISA IgG anti-salivary glands extract of Simulium nigrimanum: numbered as 1 to 22 (from the highest value and progressive decrease titers). This sample includes: 11 Pemphigus foliaceus patients (left set), and 14 controls: nine Pemphigus foliaceus relatives (middle set) and five healthy controls (right set). B - Twenty serum samples selected with the higher titres on ELISA IgG anti-salivary glands extract of Nyssomyia neivai, numbered as 1 to 20 (from the highest value and progressive decrease titers). This sample includes: nine Pemphigus foliaceus patients (left set), and 11 controls: eight Pemphigus foliaceus relatives (middle set) and three healthy controls (right set). C - Three serum samples of tegumentary leishmaniasis patients.

Figure 2. Two hypotheses trying to explain the trigger of Desmoglein-1 self-antigen reaction. A - Salivary peptides introduced into the host's skin while acquiring a blood meal triggering a antigen that cross-react with Desmoglein-1. B - Local skin inflammatory chronic reaction due to flies' bites may produce an anomalous Desmoglein-1 exposure (damaged) leading to an aberrant presentation to immune cells. 
Supplementary Tables' legends

Table 1S. Pemphigus foliaceus patients with the higher IgG antibodies titres against salivary glands extracts from Simulium nigrimanum.

Table 2S. Pemphigus foliaceus relatives with the higher $\lg G$ antibodies titres against salivary glands extracts from Simulium nigrimanum

Table 3S. Healthy endemic controls with the higher IgG antibodies titres against salivary glands extracts from Simulium nigrimanum

Table 4S. Pemphigus foliaceus patients with the higher IgG antibodies titres against salivary glands extracts from Nyssomyia neivai.

Table 5S. Pemphigus foliaceus relatives with the higher $\lg G$ antibodies titres against salivary glands extracts from Nyssomyia neivai

Table 6S. Pemphigus foliaceus neighbors with the higher $\lg G$ antibodies titres against salivary glands extracts from Nyssomyia neivai 
Figure 1. Anti-IgG human Immunoblot assay

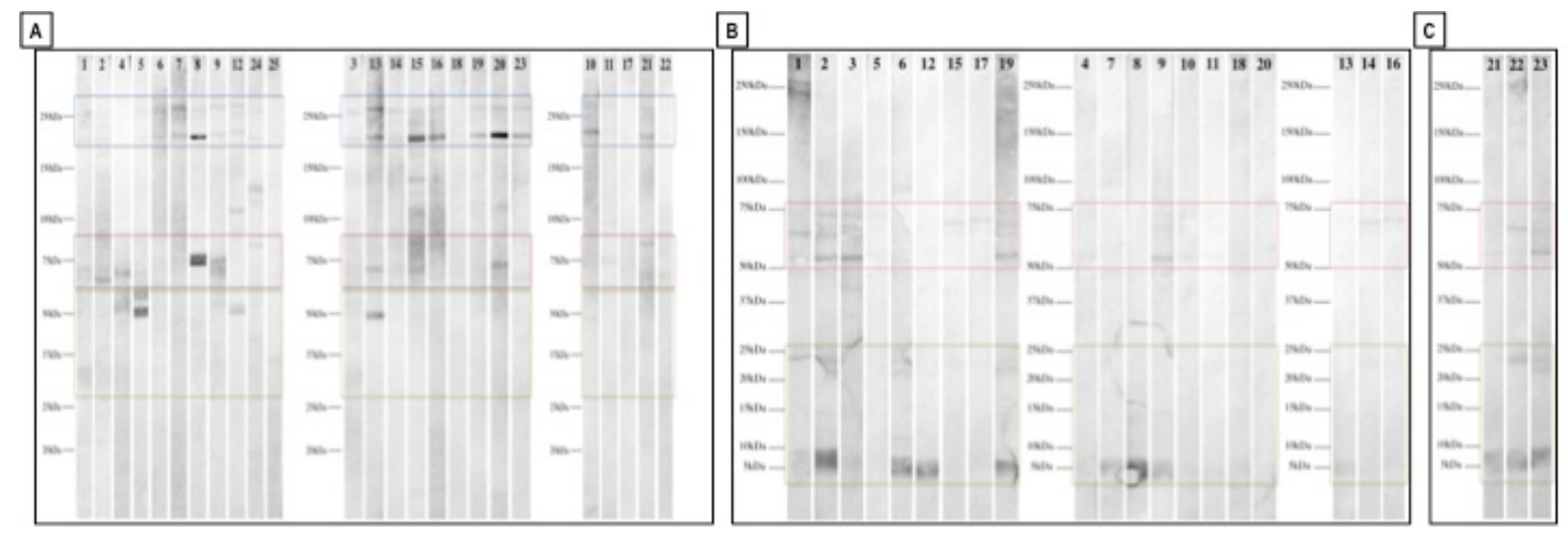


Figure 2. Two hypotheses trying to explain the trigger of Desmoglein-1 self-antigen reaction
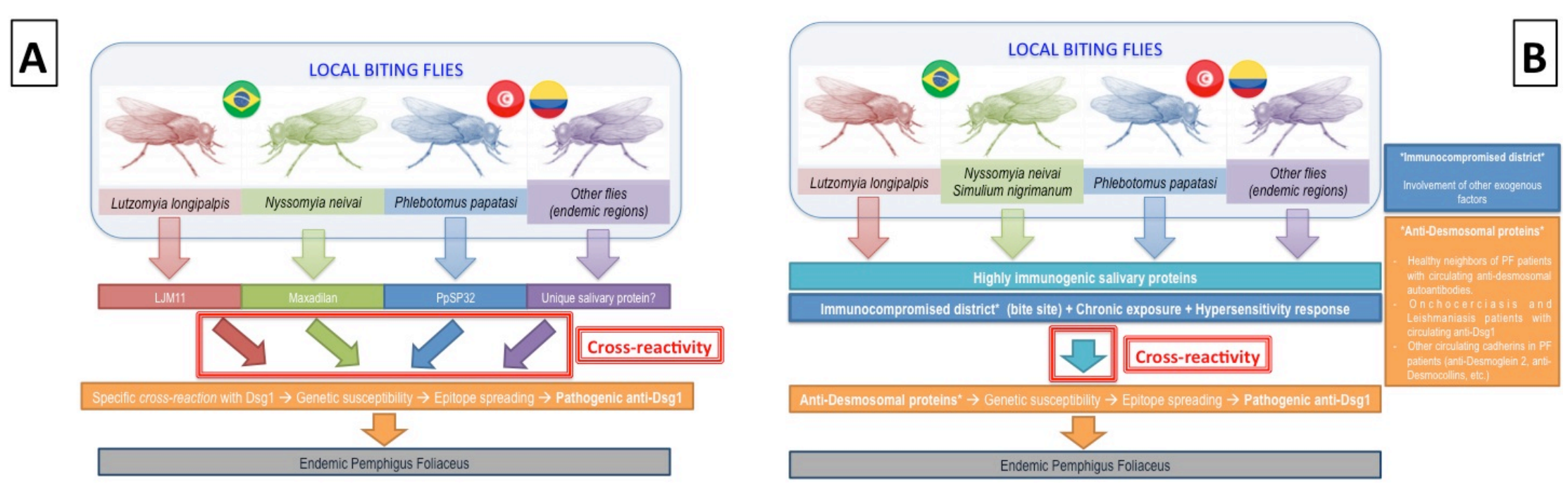
Table 1S. Pemphigus foliaceus patients with the highest IgG antibodies titres against Simulium nigrimanum SGE

\begin{tabular}{|c|c|c|c|c|c|c|c|c|c|c|c|}
\hline \multicolumn{12}{|c|}{ Pemphigus foliaceus patients } \\
\hline & $\begin{array}{c}\text { 1Sn } \\
(3 N y)\end{array}$ & $\begin{array}{c}2 \mathrm{Sn} \\
(5 \mathrm{Ny})\end{array}$ & $\begin{array}{c}4 \mathrm{Sn} \\
(17 \mathrm{Ny})\end{array}$ & $5 \mathrm{Sn}$ & $\begin{array}{c}\text { 6Sn } \\
(1 \mathrm{Ny})\end{array}$ & $\begin{array}{c}7 \mathrm{Sn} \\
(15 \mathrm{Ny})\end{array}$ & $\begin{array}{l}\text { 8Sn } \\
(2 \mathrm{Ny})\end{array}$ & 9Sn & $\begin{array}{l}\text { 12Sn } \\
(12 \mathrm{Ny})\end{array}$ & 24Sn & 2 \\
\hline $\begin{array}{c}\text { Anti-SGE } S . \\
\text { nigrimanum }(\mathrm{OD})\end{array}$ & 1.589 & 1.404 & 1.274 & 1.251 & 1.244 & 1.219 & 1.202 & 1.192 & 1.034 & 0.734 & 0 . \\
\hline $\begin{array}{l}\text { Anti-SGE } N y . \\
\text { Neivai }(\mathrm{OD})\end{array}$ & 1.561 & 1.398 & 0.759 & 0.331 & 1.888 & 0.868 & 1.736 & 0.605 & 0.985 & 0.534 & 0. \\
\hline Anti-Dsg1 (U/ml) & 269.8 & 146.2 & 166.8 & 92.8 & 100.9 & 20.1 & 193.0 & 106.3 & 188.4 & 163.2 & 11 \\
\hline Age (years) & 33 & 32 & 17 & 59 & 48 & 52 & 28 & 25 & 36 & 46 & \\
\hline Sex & $\mathrm{F}$ & $\mathrm{M}$ & $\mathrm{M}$ & $\mathrm{F}$ & $\mathrm{F}$ & $\mathrm{F}$ & $\mathrm{M}$ & $\mathrm{F}$ & $\mathrm{M}$ & $\mathrm{F}$ & \\
\hline Ethnic & B & $\mathrm{C}$ & $\mathrm{C}$ & $\mathrm{C}$ & $\mathrm{Mu}$ & $\mathrm{C}$ & $\mathrm{C}$ & $\mathrm{C}$ & $\mathrm{C}$ & $\mathrm{C}$ & \\
\hline $\begin{array}{c}\text { Duration of disease } \\
\text { (years) }\end{array}$ & 1 & $>1$ & 0.5 & $<0.5$ & $>1$ & $>1$ & $<0.5$ & $>1$ & $>1$ & $>1$ & \\
\hline Treatment & Virgin & Virgin & Virgin & Yes & Yes & Yes & Virgin & Yes & Yes & Yes & $\bar{y}$ \\
\hline
\end{tabular}

Sn: Simulium Nigrimanum. Ny: Nyssomyia neivai. SGE: salivary gland extracts; OD: optical density; Dsg1: desmoglein 1; M: male; F: Female; C: Caucasian; B: Black; Mu: Mulatto; PF: pemphigus foliaceus. 
Table 2S. Pemphigus foliaceus relatives with the higher IgG antibodies titres against salivary glands extracts from Simulium nigrimanum

\begin{tabular}{|c|c|c|c|c|c|c|c|c|c|}
\hline \multicolumn{10}{|c|}{ Pemphigus Foliaceus relatives } \\
\hline & $\begin{array}{c}\text { 3Sn } \\
(11 \mathrm{Ny})\end{array}$ & $\begin{array}{c}\text { 13Sn } \\
(7 \mathrm{Ny})\end{array}$ & 14Sn & 15Sn & 16Sn & $\begin{array}{l}\text { 18Sn } \\
(8 \mathrm{Ny})\end{array}$ & 19Sn & $\begin{array}{c}20 \mathrm{Sn} \\
(20 \mathrm{Ny})\end{array}$ & $\begin{array}{c}\text { 23Sn } \\
(10 \mathrm{Ny})\end{array}$ \\
\hline Anti-SGE S. nigrimanum (OD) & 1.356 & 0.927 & 0.899 & 0.887 & 0.867 & 0.826 & 0.821 & 0.804 & 0.738 \\
\hline Anti-SGE Ny. Neivai (OD) & 1.090 & 1.299 & 0.356 & 0.202 & 0.663 & 1.214 & 0.312 & 0.694 & 1.152 \\
\hline Anti-Dsg1 (U/ml) & 1.0 & 1.6 & 0.6 & 0.0 & 37.8 & 0.7 & 1.9 & 0.9 & 0.7 \\
\hline Age (years) & 17 & 41 & 57 & 42 & 60 & 49 & 57 & 48 & 60 \\
\hline Sex & $\mathrm{M}$ & $\mathrm{F}$ & $\mathrm{F}$ & $\mathrm{F}$ & $\mathrm{F}$ & $\mathrm{F}$ & $\mathrm{F}$ & $\mathrm{F}$ & $\mathrm{F}$ \\
\hline Ethnic & N.A. & $\mathrm{C}$ & $\mathrm{C}$ & N.A. & N.A. & $\mathrm{C}$ & $\mathrm{Mu}$ & N.A. & $\mathrm{C}$ \\
\hline Relation with PF case & Son & Sister & Mother & Mother & Mother & Sister & Sister & Sister & Mother \\
\hline
\end{tabular}

SGE: salivary gland extracts; OD: optical density; Dsg1: desmoglein 1; M: male; F: Female; C: Caucasian; Mu: Mulatto; PF: pemphigus foliaceus; N.A.: not available. 
Table 3S. Healthy endemic controls with the higher IgG antibodies titres against salivary glands extracts from Simulium nigrimanum

\begin{tabular}{|cccccc|}
\hline & Healthy endemic controls & & \\
\hline & $\begin{array}{c}\mathbf{1 0 S n} \\
(\mathbf{1 7 N y})\end{array}$ & $\begin{array}{c}\mathbf{1 1 S n} \\
\mathbf{( 1 0 N y})\end{array}$ & $\begin{array}{c}\mathbf{1 7 S n} \\
(\mathbf{1 1 N y})\end{array}$ & $\mathbf{2 1 S n}$ & $\mathbf{2 2 S n}$ \\
\hline Anti-SGE S. nigrimanum (OD) & 1.155 & 1.084 & 0.848 & 0.753 & 0.744 \\
\hline Anti-SGE N. Neivai (OD) & 0.777 & 0.915 & 0.904 & 0.354 & 0.561 \\
\hline Anti-Dsg1 (U/ml) & 1.2 & 1.1 & 0.3 & 0.3 & 3.5 \\
\hline Age (years) & 59 & 52 & 59 & 49 & 37 \\
\hline Gender & $\mathrm{M}$ & $\mathrm{M}$ & $\mathrm{M}$ & $\mathrm{M}$ & $\mathrm{M}$ \\
\hline Ethnic & N.A. & $\mathrm{Mu}$ & $\mathrm{Mu}$ & $\mathrm{Mu}$ & N.A. \\
\hline
\end{tabular}

SGE: salivary gland extracts; OD: optical density; Dsg1: desmoglein 1; M: male; Mu: Mulatto; PF: pemphigus foliaceus; N.A.: not available. 
Table 4S. Pemphigus foliaceus patients with the higher IgG antibodies titres against salivary glands extracts from Nyssomyia neivai

\begin{tabular}{|c|c|c|c|c|c|c|c|c|c|}
\hline \multicolumn{10}{|c|}{ Pemphigus Foliaceus patients } \\
\hline & $1 \mathrm{Ny}(6 \mathrm{Sn})$ & $2 \mathrm{Ny}(8 \mathrm{Sn})$ & 3Ny (1Sn) & $5 \mathrm{Ny}(2 \mathrm{Sn})$ & $6 \mathrm{Ny}$ & $12 \mathrm{Ny}(12 \mathrm{Sn})$ & $\begin{array}{l}15 \mathrm{Ny} \\
(7 \mathrm{Sn})\end{array}$ & $\begin{array}{l}17 \mathrm{Ny} \\
(4 \mathrm{Sn})\end{array}$ & $19 \mathrm{Ny}$ \\
\hline $\begin{array}{l}\text { Anti-SGE } N \text {. neivai } \\
\text { (OD) }\end{array}$ & 1.888 & 1.736 & 1.561 & 1.398 & 1.330 & 0.985 & 0.868 & 0.758 & 0.729 \\
\hline $\begin{array}{c}\text { Anti-SGE } S . \\
\text { nigrimanum }(\mathrm{OD}) \\
\end{array}$ & 1.244 & 1.202 & 1.589 & 1.404 & 0.628 & 1.034 & 1.219 & 1.274 & 0.665 \\
\hline Anti-Dsg1 (U/ml) & 100.9 & 193.0 & 269.8 & 146.2 & 108.3 & 188.4 & 20.1 & 166.8 & 168.3 \\
\hline Age (years) & 48 & 28 & 33 & 39 & 55 & 36 & 52 & 17 & 49 \\
\hline Gender & $\mathrm{F}$ & $M$ & $\mathrm{~F}$ & $M$ & $\mathrm{~F}$ & $\mathrm{~F}$ & $\mathrm{~F}$ & $\mathrm{M}$ & $\mathrm{F}$ \\
\hline Ethnic & M & $\mathrm{C}$ & B & $\mathrm{C}$ & $\mathrm{C}$ & $\mathrm{C}$ & $\mathrm{C}$ & $\mathrm{C}$ & $\mathrm{C}$ \\
\hline $\begin{array}{l}\text { Duration of disease } \\
\text { (years) }\end{array}$ & $>1$ & $<0.5$ & 1 & $>1$ & $>1$ & $>1$ & $>1$ & 0.5 & 1 \\
\hline Treatment & Yes & Virgin & Virgin & Virgin & Yes & Yes & Yes & Virgin & Yes \\
\hline
\end{tabular}

Sn: Simulium Nigrimanum. Ny: Nyssomyia neivai. SGE: salivary gland extracts; OD: optical density; Dsg1: desmoglein 1; M: male; F: Female; C Caucasian; B: Black; Mu: Mulatto; PF: pemphigus foliaceus 
Table 5S. Pemphigus foliaceus relatives with the higher IgG antibodies titres against salivary glands extracts from Nyssomyia neivai

\begin{tabular}{|c|c|c|c|c|c|c|c|c|}
\hline \multicolumn{9}{|c|}{ Pemphigus foliaceus relatives } \\
\hline & $4 N$ & 7N (13S) & 8N (18S) & $9 \mathbf{N}$ & $10 \mathrm{~N}(23 S)$ & $11 N(3 S)$ & $18 \mathrm{~N}$ & $20 \mathrm{~N}(20 \mathrm{~S})$ \\
\hline Anti-SGE $N y$. neivai (OD) & 1.545 & 1.299 & 1.214 & 1.160 & 1.152 & 1.090 & 0.743 & 0.694 \\
\hline $\begin{array}{c}\text { Anti-SGE S. nigrimanum } \\
(\mathrm{OD})\end{array}$ & 0.481 & 0.927 & 0.826 & 0.685 & 0.738 & 1.356 & 0.597 & 0.804 \\
\hline Anti-Dsg1 (U/ml) & 1.591 & 1.661 & 0.764 & 2.510 & 0.796 & 1.012 & 3.421 & 0.935 \\
\hline Age (years) & N.A. & 41 & 49 & 35 & 60 & 14 & 39 & 48 \\
\hline Gender & Female & Female & Female & Female & Female & Male & Female & Female \\
\hline Ethnic & $\mathrm{C}$ & $\mathrm{C}$ & $\mathrm{C}$ & $\mathrm{C}$ & $\mathrm{C}$ & N.A & N.A. & $\mathrm{C}$ \\
\hline Relation with PF case & Daughter & Sister & Sister & Mother & Mother & Son & Sister & Sister \\
\hline
\end{tabular}

Sn: Simulium Nigrimanum. Ny: Nyssomyia neivai. SGE: salivary gland extracts; OD: optical density; Dsg1: desmoglein 1; M: male; F: Female; C: Caucasian; B: Black; Mu: Mulatto; PF: pemphigus foliaceus 
Table 6S. Pemphigus foliaceus neighbors with the higher IgG antibodies titres against salivary glands extracts from Nyssomyia neivai

\begin{tabular}{|cccc|}
\hline \multicolumn{4}{|c|}{ Pemphigus Foliaceus neighbors } \\
\hline & $\mathbf{1 0 N y}$ (11Sn) & 11Ny & 17Ny (10Sn) \\
\hline Anti-SGE N. neivai (OD) & 0.915 & 0.904 & 0.777 \\
\hline Anti-SGE S. nigrimanum (OD) & 1.084 & 0.848 & 1.155 \\
\hline Anti-Dsg1 (U/ml) & 1.163 & 0.302 & 1.283 \\
\hline Age (years) & 52 & 59 & 59 \\
\hline Gender & $\mathrm{F}$ & $\mathrm{M}$ & $\mathrm{M}$ \\
\hline Ethnic & $\mathrm{Mu}$ & $\mathrm{Mu}$ & N.A. \\
\hline
\end{tabular}

Sn: Simulium Nigrimanum. Ny: Nyssomyia neivai. SGE: salivary gland extracts; OD: optical density; Dsg1: desmoglein 1; M: male; F: Female; Mu: Mulatto 
5.2.3 Pemphigus foliaceus and sandflies biting: Assessing the humoral immune response to Maxadilan and LJM11 salivary proteins. Fator de impacto: 6,767. Formato: Original article.

Brazilian pemphigus foliaceus and sandflies: Maxadilan or LJM11?

Sebastian Vernal; Natália A. de Paula, Valdés Bollela, Ethan Lerner, Ana Maria Roselino 
British Journal of Dermatology - Correspondence

Title

Pemphigus foliaceus and sandflies biting: Assessing the humoral immune response to Maxadilan and LJM11 salivary proteins

Authors and affiliations

Vernal S. ${ }^{1}$; De Paula, N.A. ${ }^{2}$; Bollela V. ${ }^{3}$ Lerner E.A.4; Roselino A.M. ${ }^{1}$

${ }^{1}$ Division of Dermatology, Department of Clinical Medicine, Ribeirão Preto Medical School, University of São Paulo, Ribeirão Preto, São Paulo, Brazil

${ }^{2}$ Laboratory of Dermatology Section, Department of Clinical Medicine, University Hospital, University of São Paulo, Ribeirão Preto, São Paulo, Brazil

3 Division of Infectious Diseases, Department of Clinical Medicine, Ribeirão Preto Medical School, University of São Paulo, Ribeirão Preto, São Paulo, Brazil

${ }^{4}$ Cutaneous Biology Research Center, Massachusetts General Hospital, Harvard Medical School, Boston, MA, USA

Corresponding author

Ana Maria Roselino, M.D. University Hospital, Ribeirão Preto Medical School, University of São Paulo. Av. Bandeirantes 3900, Monte Alegre, Ribeirão Preto, São Paulo - 14040-900). Phone number: +55.16.36022715. Fax number: +55.16.36023315. E-mail: amfrosel@fmrp.usp.br 


\section{To the Editor,}

In 2001, Roselino et al. ${ }^{1}$ reported the first link between salivary proteins from sandflies and pemphigus foliaceus (PF) relationship, showing higher titres of lgG antibodies against Maxadilan one of the most immunogenic salivary proteins described in Lutzomyia longipalpis, in PF patients compared to controls living in a PF endemic Brazilian region. In 2012, Qian et al. ${ }^{2}$ evidenced in PF patients antibodies against LJM11 - another highly immunogenic salivary protein from Lu. longipalpis, and demonstrated that LJM11 cross-reacted with desmoglein (Dsg) 1 peptide.

Here, we evaluated the production of lgG antibodies against Maxadilan and LJM11 in PF patients and controls living in a well-known Brazilian endemic region for PF in the northeastern São Paulo state (NSPS). ${ }^{3}$ Serum samples from 60 PF patients and 160 controls were randomly selected after the Local Ethics Committee on Human Research approval. Control groups comprehended 50 PF relatives (PFR), 70 healthy controls (HC), 20 patients with visceral leishmaniasis $(V L)$ and 20 with tegumentary leishmaniasis (TL).

Commercial ELISA (MBL, Japan) detected anti-Dsg1 antibodies in those samples. Recombinant Maxadilan (rMax) was kindly provided by Dr. Lerner, and rLJM11 commercially produced by WatsonBio LLC, USA (Figure 1A). Since TL and VL patients have been certainly bitten by sand flies, to standardize the in-house ELISA for rMax and rLJM11, sera samples from $5 \mathrm{TL}$ patients with known high anti-rMax titres as reported previously by Aires et al.4; and from $5 \mathrm{VL}$ patients were tested. As control samples, $5 \mathrm{HC}$ with no medical records of leishmania infection were used. Experiments were repeated twice as described previously. ${ }^{3}$ After that, ELISA was performed with all studied sera samples.

Considering anti-rMax results, VL and TL patients exhibited similar and the highest titres. VL presented higher titres compared to PF, PFR and HC groups $(P=0.0039,0.0008$, and $<0.0001$, respectively) (Figure 1B). On the other hand, TL titres were higher than $\mathrm{HC}$ titres $(P<0.0001)$; however, there was no significance when compared to PF and PFR. Moreover, PF titres were higher than $\mathrm{HC}(P=0.0071)$, but similar to PFR. Focusing on anti-rLJM11 results, VL group showed higher titres when compared to the other groups $(P<0.0001$ for all) (Figure 1B). Anti-rMax titres were positively correlated with rLJM11 titres exclusively in VL group (Spearman test: $r=0.766 ; P<0.0001$ ) (data no shown). 
Considering all values of the studied groups, anti-rMax but not anti-rLJM11 correlated with anti-Dsg1 titres ( $r=0.226, P$-value $=0.0022$ and $r=-0.030, P$-value $=0.6870$, respectively) (data no shown). Considering the titres of PF group, anti-rMax but not anti-rLJM11 correlated with anti-Dsg1 titres (Figure 1C).

Endemic PF foci in NSPS revealed a prevalence of 57.5 cases per million inhabitants. ${ }^{3}$ The $H L A$ profile in this population was also clearly identified. ${ }^{5}$ Recently, an epidemiological link of PF with biting flies was confirmed by geographical distributions maps followed by the biting exposure confirmation through to humoral response assessment against salivary glands extracts (SGE) from the most widely distributed flies species, Nyssomyia neivai and Simulium nigrimanum. ${ }^{3}$

$N$. neivai, a vector of $\mathrm{TL}$, but not $L$ u. longipalpis, a vector of $\mathrm{VL}$, has been systematically collected in NSPS. ${ }^{3}$ Moreover, we confirmed a Maxadilan-simile cDNA sequence in N. neivai, ${ }^{4}$ followed by the description of the $N$. neivai sialome, revealing a Maxadilan-simile peptide (accession number JAV08642.1 - data in submission) which represents the closest relationship with the Maxadilan powerful vasodilator, suggesting that $N$. neivai salivary protein might have preserved the pharmacological properties. Notwithstanding, no similar peptides to LJM11 were evidenced. ${ }^{6}$ These data support why PF patients living in NSPS produce lgG antibodies against rMax but not against rLJM11.

Recently, we reported antibodies against SGE from N. neivai in 30 PF, 30 PFR and $30 \mathrm{HC}$ groups. Using these data compiled from Vernal et al. ${ }^{3}$ allowed us to demonstrate a strong positive correlation with anti-rMax $(\mathrm{r}=0.799, P<0.0001)$, and a fragile correlation with anti-rLJM11 ( $\mathrm{r}=0.207$, $P=0.0501$ ) (Figure 1D). These results suggest that even LJM11 peptide was not demonstrated in N. neivai sialome, there is still some cross-reactivity amongst LJM11 and other salivary proteins present in the N. neivai SGE.

Zaraa et al. ${ }^{7}$ reported the recognition of salivary proteins from the sandfly Phlebotomus papatasi by PF sera in a Tunisian PF endemic region. We also recently described the recognition of more than one salivary protein from black- and sandflies by PF patients (data in submission). ${ }^{8}$ Thus, our results support the hypothesis that not a specific salivary protein may be involved in PF etiopathogenesis. The triggering factor to the PF autoimmune process in genetically susceptible individuals could be better explained by a continuous stimulus of highly immunogenic pool of salivary proteins from biting flies rather than a single specific protein. 


\section{References}

1. Roselino AM, Figueiredo JFC, Kounga K, Reddy V, Lerner EA. Serum IgG from pemphigus foliaceus patients reacts against maxadilan. J Investig Dermatol. 2001;117:460.

2. Qian $\mathrm{Y}$, Jeong JS, Maldonado M, et al. Cutting Edge: Brazilian pemphigus foliaceus antidesmoglein 1 autoantibodies cross-react with sand fly salivary LJM11 antigen. J Immunol. 2012;189(4):1535-1539.

3. Vernal S, Pepinelli M, Casanova C, et al. Insights into the epidemiological link between biting flies and pemphigus foliaceus in southeastern Brazil. Acta Trop. 2017;176:455-462.

4. Aires J, Casanova C, Vernal S, et al. Maxadilan-simile expression in Nyssomyia neivai, a sandfly vector in an endemic region of Brazil, and its immunogenicity in patients with American tegumentary leishmaniasis. Mem Inst Oswaldo Cruz. 2017;112(2):116-122.

5. Brochado MJ, Nascimento DF, Campos W, Deghaide NH, Donadi EA, Roselino AM. Differential HLA class I and class II associations in pemphigus foliaceus and pemphigus vulgaris patients from a prevalent Southeastern Brazilian region. J Autoimmun. 2016.

6. Vernal S, Oliveira FO, Wanderson Goulart, Thaís Calo, Eric Pinto, Mara Roselino, Ana, Maria Ribeiro JMC. An insight into the Sialome of Nyssomyia neivai (Pinto 1926): a sandfly vector in Brazilian endemic area for Tegumentary Leishmaniasis and Pemphigus foliaceus (Fogo selvagem). 2019. Submitted.

7. Zaraa I, Boussoffara T, Ben Ahmed M, et al. Exposure to Phlebotomus papatasi and/or Leishmania major: possible etiologic link to Tunisian pemphigus. J Invest Dermatol. 2012;132(2):479-482.

8. Vernal S, Pepinelli M, Oliveira W, et al. Exposure to salivary proteins of biting flies may be related to Brazilian pemphigus foliaceus etiopathogenesis. 2019. Submitted. 
Figure Legends

Figure 1. A - SDS-Page (4-15\%, Bio-Rad, USA) stained by Comassie blue. Black arrow: rLJM11 protein $(43 \mathrm{kDa})$. Blue arrow: rMaxadilan protein $(\sim 6.5 \mathrm{kDa})$. B - In house ELISA results of IgG antibodies against rMax and rLJM11 in pemphigus foliaceus (PF) patients, PF relatives, healthy controls $(\mathrm{HC})$, and in visceral leishmaniasis $(\mathrm{VL})$ and tegumentary leishmaniasis $(\mathrm{TL})$ patients. C Correlation between $\lg G$ antibodies against rMax and rLJM11 and $\lg G$ autoantibodies against desmoglein 1. D - Correlation between IgG antibodies against rMax and rLJM11 and IgG antibodies against salivary gland extract (SGE) from Nyssomyia neivai (data compiled from Vernal et al. ${ }^{3}$ ).

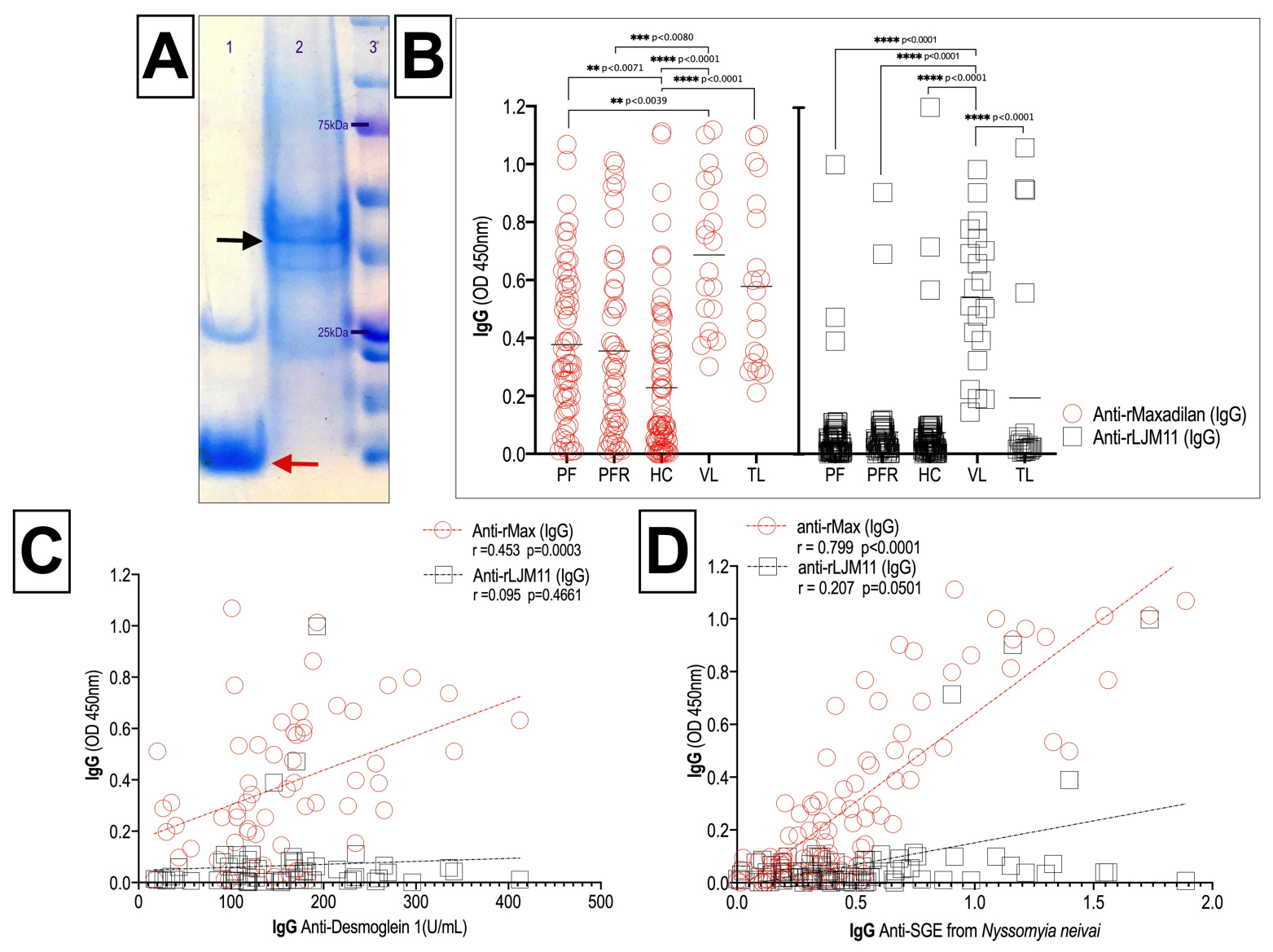


5.2.4 An insight into the Sialome of Nyssomyia neivai (Pinto 1926): a sandfly vector in Brazilian endemic area for Tegumentary Leishmaniasis and Pemphigus foliaceus (Fogo selvagem). Jornal: Parasite and Vectors Fator de impacto: 2,564 Formato: Original article.

An insight into the Sialome of Nyssomyia neivai (Pinto 1926): a sandfly vector in Brazilian endemic area for Tegumentary Leishmaniasis and Pemphigus foliaceus (Fogo selvagem)

Sebastian Vernal; Fabiano Oliveira; Wanderson Oliveira; Thaís Goulart; Eric Calvo; Mara Pinto; Ana Maria Roselino, José M. C. Ribeiro 
Title

An insight into the Sialome of Nyssomyia neivai (Pinto 1926): a sandfly vector in Brazilian endemic area for Tegumentary Leishmaniasis and Pemphigus foliaceus (Fogo selvagem)

\section{Running title}

Nyssomyia neivai sialotranscriptome

\section{Authors and Affiliations}

Sebastian Vernal18*; Fabiano Oliveira2§; Wanderson Oliveira3; Thaís Goulart3; Eric Calvo², Mara Pinto3; Ana Maria Roselino¹, José M. C. Ribeiro²

1Division of Dermatology, Department of Clinical Medicine, Ribeirão Preto Medical School, University of São Paulo, Ribeirão Preto, São Paulo, Brazil

2 Laboratory of Malaria and Vector Research, National Institute of Allergy and Infectious diseases, National Institute of Health (NIH)

3Department of Parasitology, São Paulo State University Julio de Mesquita Filho, Araraquara, São Paulo, Brazil

$\S$ This authors contributed equally to this work.

${ }^{*}$ Current address: Department of Infectious diseases, University of São Paulo, São Paulo, Brazil

\section{Corresponding author}

José M. C. Ribeiro. Laboratory of Malaria and Vector Research, National Institute of Allergy and Infectious diseases, National Institute of Health (NIH) 


\section{INTRODUCTION}

Leishmaniasis encompasses a broad spectrum of diseases caused by an obligate intramacrophage protozoan belonging to the genus Leishmania (Kinetoplastida: Trypanossomatidae), that is predominantly in tropical and subtropical regions. The parasite is transmitted by the bite of sandfly vectors (Diptera: Psychodidae: Phlebotominae), which inoculate the promastigote forms of Leishmania into the host's skin while acquiring a blood meal.1,2 During this process, the phlebotomine injects the parasite with saliva. ${ }^{2}$ The pharmacological activities of the saliva assist in blood feeding and cell functions, modulating the host's immune system. 3,4

Leishmania (Viannia) braziliensis (Viana 1911) and Leishmania (Leishmania) amazonensis (Lainson \& Shaw 1972) are the main species involved in both the cutaneous and mucocutaneous forms of Tegumentary Leishmaniasis (TL) in Brazil. ${ }^{5}$ Autochthonous cases of TL have been reported in the northeastern São Paulo state (NSPS), Southeastern Brazil. Both sand flies: Nyssomyia intermedia (Lutz \& Neiva 1912) (syn=Lutzomyia intermedia) and Nyssomyia neivai (Pinto 1926), are the main vectors of $L$. (V.) braziliensis in São Paulo state; however, only $N$. neivai has been recognized in systematic research collections in NSPS cities. ${ }^{6}$

Pemphigus foliaceus (PF) is an autoimmune bullous disease caused by autoantibodies against desmoglein (Dsg) 1. It is subdivided into classic sporadic worldwide Cazenave's pemphigus and endemic pemphigus (known in Brazil as Fogo Selvagem). Although the pathogenesis of PF remains unclear, genetic and environmental factors have been implicated in the susceptibility to this disease..$^{7,8}$ Interestingly, the salivary proteins of sandflies have been related to pemphigus etiopathogenesis. Higher levels of serum IgG against maxadilan, a highly immunogenic salivary protein described in Lutzomyia longipalpis (Lutz and Neiva 1912), a vector of visceral leishmaniasis $(\mathrm{VL})$, have been determined in PF patients as compared to healthy controls living in the same 
endemic region. ${ }^{9}$ There is also evidence that LJM11, another immunogenic protein from $L u$. longipalpis, cross-reacts with antibodies against Desmoglein (Dsg) 1, and it has been proposed as the antigen that triggers PF diagnosed in Amerindians living in Mato Grosso state, Brazil. ${ }^{10}$ Of note, Lu. longipalpis is not widely distributed in NSPS.8,11

The profile of salivary components has been defined in nine Old World Phlebotomus species; ${ }^{12-19}$ notwithstanding, the sialotranscriptome of the New World sandflies have been documented only in four species: Bichromomyia olmeca (Vargas and Diaz-Najera 1959) (syn=Nyssomyia olmeca), Lutzomyia ayacuchensis (Caceres and Galati 1988), Lu. longipalpis and N. intermedia. ${ }^{20-23}$ Considering the vector-based vaccines for Leishmania sp. infection, and to assess a possible candidate protein that might be the trigger of anti-Dsg1 autoantibodies in Brazilian endemic

PF in NSPS, we describe the sialome of $N$. neivai and to compare it to: $N$. intermedia ${ }^{21}$ (the main vector of Leishmania (V.) braziliensis in the coastal SP state), and Lu. longipalpis ${ }^{22}$ (the vector of VL in SP state), pemphigus etiopathogenesis. ${ }^{25,26}$

\section{METHODS}

\section{Collection and maintenance of sand flies}

Sand flies were collected in Santa Eudóxia, SP state - Brazil (along the edges of the Mogi Guaçu River) on the wall of a house, using a manual aspirator between 18:00hs and 23:00hs. In the laboratory, the sand flies were maintained in cages covered with voile $\left(30 \mathrm{~cm}^{3}\right)$ at $26 \pm 1^{\circ} \mathrm{C}, 80-90 \%$ humidity, and a 12:12 (L:D) photoperiod. Salivary glands were extracted as described previously. ${ }^{27}$

\section{Salivary gland transportation}


Two hundred pairs of salivary gland tissue samples were submitted in $1 \mathrm{~mL}$ RNA Later each to the North Carolina State Genomic Sciences Laboratory (Raleigh, NC, USA) for RNA extraction, Illumina library preparation, and sequencing. The salivary glands tissue samples exportation was approved by the United States Department of Agriculture - Veterinary Permit under the ID number $\# 130339$.

\section{Salivary gland RNA extraction}

Prior to extraction, salivary glands were pelleted by the addition of $1 \mathrm{~mL}$ PBS in a benchtop centrifuge at $5000 \mathrm{xg}$ for $10 \mathrm{~m}$ to remove the RNA Later. Total RNA was extracted using the RNeasy Mini Kit (Qiagen, MD, USA) following the manufacturer's protocol for purification of total RNA from animal tissue. Briefly, Qiagen RLT buffer with $\beta$-Mercaptoethanol ( $\beta$-ME) was added to the tissue samples and samples were homogenized using a Qiagen TissueLyser with $5 \mathrm{~mm}$ stainless steel beads (Qiagen). Samples were then purified with provided RNeasy spin columns. Total RNA was then assessed for purity and size integrity using an Agilent 2100 Bioanalyzer with an RNA 6000 Nano Chip (Agilent Technologies, CA, USA). Purification of messenger RNA (mRNA) was performed using oligo-dT beads provided in the NEBNExt Poly(A) mRNA Magnetic Isolation Module (New England Biolabs, MA, USA). Complementary DNA (cDNA) libraries for Illumina sequencing were constructed using the NEBNext Ultra Directional RNA Library Prep Kit (NEB) and NEBNext Multiplex Oligos for Illumina (NEB) using the manufacturer-specified protocol.

\section{Sialome library}


Briefly, the mRNA was chemically fragmented and primed with random Oligos for first strand cDNA synthesis. Second strand cDNA synthesis was then carried out with dUTPs to preserve strand orientation information. The double-stranded cDNA was then purified, end repaired and "a-tailed" for adaptor ligation. Following ligation, the samples were selected for a final library size (adapters included) of 400-550bp using sequential AMPure XP bead isolation (Beckman Coulter, USA). Library enrichment was performed and specific indexes for each sample were added during the protocolspecified PCR amplification. The amplified library fragments were purified and checked for quality and final concentration using an Agilent 2200 Tapestation (D1000 chip, Agilent Technologies, USA) combined with a Qubit fluorometer (Thermo-Fisher, MA, USA). The final quantified libraries were pooled in equimolar amounts for clustering and sequencing on an Illumina HiSeq 2500 DNA sequencer, utilizing a 125bp single-end cycle sequencing kit (Illumina, CA, USA). The software package Real Time Analysis (RTA), was used to generate raw bcl, or base call files, which were then de-multiplexed by sample into fastq files using bcl2fastq Conversion Software v2.17 (Illumina, CA, USA).

\section{Bioinformatics}

Custom bioinformatic analysis were describe elsewhere ${ }^{28}$. Succinctly, low quality reads were trimmed from Fastq files $(<20)$ and contaminating adapter primer sequences removed. De novo assembly from reads was a result of Abyss (using k parameters from 21 to 91 in 5 -fold increments $)^{29}$ and SOAP de novo-trans ${ }^{30}$ assemblers. The fasta files were combined and further assembled using an iterative blast and CAP3 pipeline as previously described ${ }^{31}$. Coding sequences (CDs) were extracted based on the existence of a signal peptide in the longer open reading frame (ORF) and by similarities to other proteins found in the Refseq invertebrate database from the 
National Center for Biotechnology Information (NCBI), proteins from "diptera[organism]" deposited at NCBI's Genbank and from SwissProt. Contigs containing an open reading frame and/any similarity to sequences in the chosen databases were selected for further analysis. Reads for each library were mapped on the deducted CDs using blastn with a word size of 25, 1 gap allowed and 95\% identity or better required. Up to five matches were allowed if and only if the scores were the same as the largest score. Mapping of the reads was also included in the Excel spreadsheet. Values of the Reads Per Kilobase of transcript, per Million mapped reads (RPKM) 32 for each coding sequence were also mapped to a sprea]dsheet. Automated annotation of proteins was based on a vocabulary of nearly 350 words found in matches to various databases, including Swissprot, Gene Ontology, KOG, Pfam, and SMART, Refseq-invertebrates and the diptera subset of the GenBank sequences obtained by querying diptera[organism] and retrieving all protein sequences. Raw reads were deposited on the Sequence Read Archive (SRA) of the National Center for Biotechnology Information (NCBI) under bioproject ID PRJNA359206. This Transcriptome Shotgun Assembly project has been deposited at DDBJ/EMBL/GenBank under the accession SAMN0618923.

\section{Phylogenetic analysis}

For multiple sequence alignment and phylogenetic analysis PkanSILK, PkanYLW, PkanSP15 had their predicted signal peptide signal (SignallP-5.0 sever [49]) removed and resulting protein sequence entered into a Basic Local Alignment Search tool (BLAST) against nr and tsa_nr databases. Homolog sequences were included if E-value was below 1-10 and belonged to the sand fly genera, with the exception of PkanYLW where a homologue from drosophila was used to root the tree. Multiple sequence alignment and identity/similarity matrix were constructed on MacVector (Version 15.5.3) with MUSCLE using PAM 200 profile. In order to determine the best method for estimating Maximum 
Likelihood phylogenetic trees, the "Find best protein Models" feature of MEGA7[44] was utilized. Through this feature, it was determined that the best method for modeling phylogeny for PkanSILK was $J T T+G+1$, PkanYLW was WAG+G and PkanSP15 was WAG+G+l. For Gaps/Missing data treatment, a partial deletion option was utilized. Finally, the reliability of the trees were tested, by bootstrap method ( $\mathrm{N}=1000)$. Nodes with $<70 \%$ reliability were removed. 


\section{RESULTS AND DISCUSSION}

\section{cDNA library of Nyssomyia neivai salivary gland}

cDNA library was constructed from salivary glands of $N$. neivai females dissected one day after emergence. From this cDNA library 1,302,396 high quality reads were assembled in 1200 contigs (Table 1). Contigs were classified in five categories namely: secreted, housekeeping, transposable elements, viral and unknown. Remarkably, the secreted proteins category comprised $41.2 \%$ of the contigs and $92.4 \%$ of the number of reads. All previous salivary transcriptomes were based in low output cDNA library sequencing, nevertheless a high abundance of transcripts encoding secreted proteins were also reported. . $3-16,19,21,33,34$ Our data further validates the specialization of the salivary gland machinery and the specificity of the material obtained with the sand fly dissection. The

housekeeping category had $33.3 \%$ of the clusters and $3.2 \%$ of the total sequences. The category of "unknowns" comprised $24.6 \%$ of the cluster and $4.3 \%$ of the sequences. Finally, Viral products and transposable elements included less than $1 \%$ of the families ( $0.3 \%$ and $0.8 \%$ respectively) and less than $0.1 \%$ of total sequences.

\section{Housekeeping and Unknow proteins sequences}

The 399 clusters (comprising 42,119 sequences) attributed to Housekeeping genes expressed in the salivary glands of $N$. neivai were further divided into 22 subgroups according to their function. Two sets were associated with (a) protein synthesis machinery (22 contigs), including translation, ribosomal structure and biogenesis, and (b) metabolism (94 contigs), a pattern also 
observed in other sialotranscriptomes. Proteins with unknown function (295 contigs comprising 4.3\% of reads) were classified as "unknown".

\section{$>$ Secreted proteins sequences}

The putative secreted salivary proteins of $N$. neivai were classified into 35 main protein families (Table 2). The most abundant transcripts were SP13-15 protein family (34.4\%), followed by C-type lectins (15.9\%), Maxadilan (15.6\%), ML domain salivary proteins (5.8\%), Yellow protein family (5.1\%), Apyrase (1.5\%) and 10-kDa family (3.4\%). The following paragraphs describe the most

important families in detail, focusing on protein family characteristics, possible function, biochemical, immune-modulatory, and antigenic properties, and phylogenetic analysis in context with related proteins from other Brazilian sandflies, S. nigrimanum's sialome and desmogleins proteins.

\section{SP13-15 family}

SP15 family was described for the first time in the sialome of Phlebotomus perniciosus (Newstead 1911), and was named after 15-kDa salivary protein of Phlebotomus papatasi (Scopoli 1786) (PpSP15: AF335487). ${ }^{15}$ Thus far, SP15-like proteins have only been reported in sandflies and not in any other Diptera; Alvarenga et al., 2013,35 demonstrated that SP15 from Phlebotomus duboscqi (Neveu-Lemaire 1906) inhibit anionic surface-mediated reactions suggesting a role in anticoagulation, inhibiting the activation of $\mathrm{FXII}$ and $\mathrm{FXI}$, and anti-inflammatory processes.

It has been suggested that SP15-like proteins were derived from an ancestral odorant-binding protein and were closely related to short D7 proteins..$^{12,15}$ The SP15 family is an abundant salivary family among other species of sandflies, and in N. neivai is the most abundant salivary protein with $34.4 \%$ of the RPKM belonging to the SP13-15 family. 
PpSP15-like proteins were reported as promising anti-Leishmania vaccine candidates. Immunization of mice with $P$. papatasi SP15 protein conferred partial protection against Leishmania (Leishmania) major (Yakimoff and Schokhor 1914) infection;33 furthermore, a DNA vaccine containing the PpSP15 cDNA provided the same protection. ${ }^{33}$ ParSP03 (AAX56359), a PpSP15-like protein from Phlebotomus ariasi (Tonnoir 1921), elicited similar delayed type hypersensitivity and humoral immune responses upon DNA vaccination. ${ }^{16}$ Recently, BALB/c mice immunized to PsSP19 (HM56964), a protein member of the SP15 family from Phlebotomus sergenti (Parrot 1917), acts as an adjuvant to accelerate the cell-mediated immune response to co-administered Leishmania antigens, providing protection against Leishmania (Leishmania) tropica (Wright 1903) infection. ${ }^{36}$

Phylogenetic analysis of N. neivai SP13-15 family grouped these proteins in a New World sandflies cluster next to $B$. olmeca, Lu. ayacuchensis and $N$. intermedia proteins, and to the only one SP-15 family protein described in Lu. longipalpis so far, SL122 (AAD32197.1) (Figure 1A). N. neivai SP-15 proteins were align to $N$. intermedia and Lu. longipalpis proteins of the same cluster tree (Figure 1B). SL1 from Lu. longipalpis is closely related to Lu. ayacuchensis SP-15 proteins. ${ }^{20}$ Despite, N. neivai SP13-15 family proteins shared a 47 to $56 \%$ of identity and 67 to $79 \%$ of similarity to SL1.

JAV08231 shared 90\% identity and 92\% similarity with Linb-8 (AFP99232.1) of N. intermedia. Interestedly, BALB/c immunization with DNA plasmids encoding Linb-8 induced the highest humoral immune response against $N$. intermedia salivary gland homogenate (SGH), even greater than Linb-7 (AFP99230.1), another SP-15 protein also tested. ${ }^{21}$ Linb-7-immunized mice induce a strong humoral response leading to a sustained local inflammatory process, which may exacerbate Leishmania sp. infection by L. (V). braziliensis. ${ }^{21}$ On the other hand, Linb-11 (AFP99228.1), a 4.5kDA molecule from the SP-13 family, induces low humoral, and controlled cellular immune responses in Linb-11immunized mice, resulting in a better $L$. (V). braziliensis infection control;21 notwithstanding, no 
significant alignments were found between Linb-11 and N. neivai salivary proteins. Regarding N. neivai and $N$. intermedia are the two vector of $L$. (V). braziliensis in Southeastern Brazil, similarities between JAV08231 and Linb-8 may be interested target to a vector-based vaccine for TL in Brazil.

\section{C-type lectins family and Lufaxin-like proteins}

In animals, protein-carbohydrate interactions serve multiple functions in the immune system. C-type lectins family is component of the innate immune response, pathogen neutralization through the complement pathway, and adaptive immune response. ${ }^{37}$ Homologous proteins with molecular weight of 16.2-16.5 kDa have been identified from Lu. Iongipalpis saliva. ${ }^{22}$ This putative domain may function as a $\mathrm{Ca}^{+2}$-dependent carbohydrate-binding pocket involved in extracellular matrix organization, pathogen recognition and cell-to-cell interactions. ${ }^{37}$ The exactly role of this proteins in sandflies remains elusive.

At the end of the last century, the anticoagulant activity of Lu. longipalpis salivary proteins was attributed to a C-type lectin-like protein. ${ }^{38}$ Years later, expression and testing of recombinant salivary proteins from Lu. longipalpis identified a 32-kDa protein responsible for the anticoagulant activity named as Lufaxin (Lutzomyia Factor Xa inhibitor) ${ }^{39}$ (AAS05319.1). Others Lufaxin-like proteins have also been described in New world and Old world sand flies, suggesting a preserved anticoagulation property. ${ }^{13-16,19,21,33}$

Linb-17 (AFP99233.1) from N. intermedia sialome ${ }^{21}$ shared a $53 \%$ identity and $69 \%$ similarity with Lufaxin, but $N$. neivai salivary proteins do not shared any significant alignment with both. Only another C-type lectin-like protein from N. intermedia, Linb-22 (AFP99236.1), shared some similarities

with two N. neivai proteins, JAV08581.1 and JAV08563.1 (56 and 57\% similarity respectively) 
(Figure 2A and 2B); notwithstanding, the pharmacological properties and a supposed anticoagulation activity are still unknown.

\section{Maxadilan-like family}

Maxadilan (AAA29288.1) is a 7-kDa peptide present in the salivary gland of the sandfly Lu. longipalpis. Max was the first molecule to be identified in the sandfly saliva, ${ }^{40}$ and it is recognized for its powerful vasodilator effect. Inoculation of Maxadilan in experimental animals exacerbates Leishmania infection to the same degree as the whole salivary gland. ${ }^{41}$ This peptide can drive a Th1 response to Th2, to up-regulate IL-10 and TGF- $\beta$ production, and it suppresses IL-12p40, TNF- $\alpha$, and NO production. 42,43

In animal models, mice vaccinated with maxadilan become markedly protected against Leishmania infection, producing not only anti-maxadilan antibodies, but also immunized CD4+ T cells against maxadilan, to generate IFN- $\gamma$ and induce NO production. ${ }^{41}$ Notoriously, immunization against maxadilan also inhibits correct blood meal acquisition by sandflies, so immunization could help to block the vector reproduction process. ${ }^{44}$ Nonetheless, maxadilan is not free of polymorphism; its aminoacids substitution is around $23 \%$, and some aminoacids sequences are not conserved. 45,46

Maxadilan-like proteins have never been identified in Old World Phlebotomus species. ${ }^{13-}$ 16,19,21,33 Phlebotomus sandflies except for $P$. duboscqi, lack of adenosine deaminase (ADA) that hydrolyze adenosine and adenosine monophosphate (AMP) ${ }^{14-16,19}$, but contain large amounts of adenosine and AMP ${ }^{47,48}$. In contrast, Lu. longipalpis has ADA and lacks adenosine and AMP in the saliva.22,38 Unexpectedly, neither ADA nor maxadilan were identified in Lu. ayacuchensis. Thus, with those exceptions, in general salivary vasodilators of sandflies are considered to be adenosine and AMP in Phlebotomus complex, and maxadilan in Lutzomyia complex. 
Linb-147 (JK846521) from $N$. intermedia showed a relatively low match to maxadilan, provided for only $34 \%$ identity and $70 \%$ similarity over a stretch of 50 amino acids. Moreover, this sequence is scarcely present in $N$. intermedia sialome, only one transcript was identified in the present CDNA library as compared to 30 transcripts of maxadilan present in Lu. longilpalpis sialome..$^{21,22}$

JAV08642.1 present in N. neivai sialome is closely related to Maxadilan (Figure 3A), evidenced a match $2 \mathrm{e}-05$ providing $47 \%$ of identity and $68 \%$ similarity over a stretch of 49 amino acids (Figure 3B). In contrast to the other two New Worlds sandflies' sialomes, Lu. ayacuchensis and N. intermedia, JAV08642.1 represent the closest relationship with this powerful vasodilator, suggesting that $N$. neivai may have preserved this pharmacological properties. ${ }^{49}$ Furthermore, regarding $L u$. longipalpis as vector of $V L$ and $N$. neivai as vector of $T L$ in the same endemic Brazilian regions ${ }^{6,50}$ Maxadilan-like proteins could bring new insight in a common vaccine for $V L$ and $T L$.

The novel families 8-kDa, 6-kDa and 5-kDa only described in N. intermedia sialome until now, ${ }^{21}$ they where now grouped next to $N$. neivai peptides; but their functions and properties remain unknown.

\section{ML domain peptide family}

The MD-2-related lipid-recognition (ML) domain is implicated in lipid-mediated membrane binding mechanisms with a critical role in the execution and regulation of many cellular processes, including cell signaling and membrane trafficking. ${ }^{51}$ The ML domain from the SMART database also indicates proteins involved in innate immunity. 52

This family is relatively common in tick sialomes; 52 but it had only been described in $N$. intermedia sialome so far and not another sandfly transcriptomes. ${ }^{21} \mathrm{~N}$. neivai salivary peptides now 
join these family proteins of $N$. intermedia in two main clusters (Figure $4 \mathrm{~A}$ ), expanding the initial 5 sequences reported (Figure 4B).

\section{Yellow protein family}

Yellow-related proteins are abundantly expressed in salivary glands of sandflies. 13-16,19,21,33,34 Phlebotomine yellow-related proteins are characterized by the presence of major royal jelly protein domain (MRJP). Originally, MRJP proteins were described from honeybee larval jelly, making up to $90 \%$ of the protein content. ${ }^{53}$ Sequences related to MRJP proteins were described in Drosophila, where it is related to cuticle pigmentation and, when mutated, it produced a yellow phenotype and thus named Yellow proteins. ${ }^{54}$

In bloodsucking Diptera, salivary yellow-related proteins have only been described in sand flies (all sand fly species studied to date) ${ }^{13-16,19,21,33,34}$, and some black flies. ${ }^{55}$ Regarding the black fly of the gender Simulium, they are no descriptions of yellow-related proteins in the Simulium vittatum (Zetterstedt 1838) and S. nigrimanum sialomes. ${ }^{24,56}$

The proteins of this family are immunogenic and host antibody responses to this protein can be a potential marker for sandfly exposure in experimentally bitten mice and dogs, as well as naturally exposed dogs, humans, and foxes. ${ }^{57}$ Lu. longipalpis proteins, LJM11, LJM111 and LJM17, act as high affinity binders of pro-inflammatory biogenic amines such as serotonin, catecholamines and histamine, suggesting that the proteins play a role for the reduction of inflammation during sand fly blood-feeding. ${ }^{58}$

A combination of recombinant LJM17 (AAD32198.1) and LJM11 (AAS05318.1) successfully substituted Lu. longipalpis whole SGH in probing sera of individuals for vector exposure. ${ }^{27}$ Yellow proteins are also under consideration for anti-Leishmania vector-based vaccines. LJM17 from $L$. 
longipalpis elicited leishmanicidal Th1 cytokines in immunized dogs,59,60 and LJM11 protected laboratory animals against L. (L.) infantum (Nicolle 1908), L. (L.) major and L. (V.) braziliensis.58,61,62

In contrast, mice immunized with P. papatasi yellow-related proteins PpSP42 or PpSP44 (AAL11052 and AAL11051, respectively) elicited Th2 cytokines and exacerbated L. (L.) major infection. ${ }^{63}$ Other yellow-related proteins from P. papatasi, specifically PPTSP36 (AGE83101.1), induce a strong Th1 response constituting potential vaccine candidates against leishmaniasis. ${ }^{64}$ It remains to be elucidated whether the protection induced by yellow-related proteins is related to particular protein immunogenicity, to sandfly species, or to the vector-Leishmania host combination, as all of these factors can contribute to vaccine efficacy. New approached using novel vaccine techniques consisting in a single dose of plasmid followed by two doses of recombinant Canarypoxvirus expressing Lu. longipalpis yellow-related salivary proteins are a promised strategy to control Leishmania infection. 60

N. intermedia sialome exhibited two yellow-related proteins with significant alignments to LJM11 and LJM17, Linb-30 (AFP99277.1) and Linb-21 (AFP99235.1) respectively. ${ }^{21}$ LayS118 (BAM69185.1) from Lu. ayacuchensis salivary gland also evidenced match with LJM17 (identity 68\%, similarity $81 \%$ ) and LJM11 (identity $54 \%$, similarity $72 \%$ ). In the same way, N. neivai sialome positioned yellow-related protein in the New World sandflies cluster (Figure 5A); grouped next Linb21 other two proteins, JAV07958.1 and JAV07968.1) closed related to LJM17 (61-62\% identity and 78-79\% similarity), but not as LayS118. Also highlights the proximity of JAV07960.1 and Linb-30 (identity 99\% similarity 99\%); however, Linb-30 has a more significant alignment to LJM11 from Lu. longipalpis (identity $79 \%$ and similarity $88 \%$ against $72 \%$ identity and $84 \%$ similarity when compared to JAV07960.1) (Figure 5B). 


\section{Apyrase family}

Apyrases are nucleoside triphosphate-diphosphohydrolases present in a variety of organisms. Apyrase appears to be a universal enzyme used to prevent blood coagulation by diverse hematophagous animals such as bloodsucking leeches, ticks, triatomine bugs, fleas, and mosquitoes. This enzyme hydrolyses both ATP and ADP to AMP, thus destroying an important physiologic stimulus of platelet aggregation released from damaged tissues and blood cells. ${ }^{65}$

In the saliva of blood sucking arthropods, apyrases function to hydrolyze ADP in a $\mathrm{Ca}^{+2}$ dependent manner and inhibit ADP-induced platelet aggregation to facilitate blood feeding. ${ }^{65}$ The apyrase from sand flies belongs to the Cimex family of apyrases ${ }^{33}$ and is very distinct from the 59 nucleotidase family of proteins found in mosquitoes. ${ }^{66}$

Due the Apyrase property to induce a strong Th1 response, it has also been target of study as promising vaccine candidates against leishmaniasis. ${ }^{64}$

Linb-45 (AFP99246.1) showed 66\% identity with L. longipalpis salivary apyrase (AAD33513.1) and with Lu. ayacuchensis apyrase (BAM69098.1).

\section{Simulium nigrimanum, a endemic blackfly related to pemphigus foliaceus in northeastern} São Paulo state

Historically, PF was distributed in rural areas and surrounding watersheds, which reinforces the hypothesis that insects bites might be associated to PF.8,25 Recently, the epidemiological link between $N$. neivai and S. nigrimanum and PF was confirmed in NSPS by spatial geographical distribution maps, where PF foci overlap with these insects distribution. ${ }^{8}$

In 2010, Ribeiro et al. ${ }^{24}$ compared the peptide sequence of the $S$. nigrimanum sialotranscriptome with the peptide sequence of Dsg to identify some candidate proteins that could 
induce anti-Dsg1 cross-reactivity: the collagen-like family. Although these authors found some similarity, no cross-reactivity with salivary peptide has been proven so far.

Focusing in NSPS PF endemic foci, PF patients and their relatives presented higher titres of IgG antibodies against SGH of both, S. nigrimanum and N. neivai, but not against mosquito Aedes aegypti (Linnaeus, 1762) (used as endemic vector control) when compared to their healthy controls living in the same endemic area. ${ }^{8}$ Vernal et al., also described a positive correlation between the antibodies against SGH from S. nigrimanum and N. neivai in the three studied groups: PF patients, PF patients' relatives and healthy endemic controls. ${ }^{8}$ This correlation shows that exposure to the bites of both species is possible because they are similarly distributed in NSPS, but also similar antigen effects between both flies may be involved in PF etiopathogenesis. Although S. nigrimanum and $N$. neivai are two species far way in evolution time line, they converge in Diptera family (Nematocera order). ${ }^{67}$ Host's hemostasis represents a barrier to efficient vectors' blood feeding. Considering this feeding mode evolved independently in several insect orders and families, the salivary composition among insects is typical of a convergent evolutionary scenario due to the vertebrate host immune pressure over the salivary products. ${ }^{68,69}$ For example, Simplagrin (ACZ28269) from S. nigrimanum, and Aegyptin from mosquitos have low similarity at amino acid level; notwithstanding, the retained the same biological function: platelet aggregation inbition. ${ }^{70}$ Thus, despite no significant alignment between $S$. nigrimanum and N. neivai salivary proteins were found, similar pharmacological properties and/or conformation mimotopes and/or antigenic effects may not be discharge as responsible for the immune-tolerance loss to Dsg1 in genetically susceptible individuals. Further studies are necessary to assess this hypothesis.

\section{$>$ Nyssomyia neivai, flies and Desmoglein-1}


Since $2001,{ }^{9}$ sandflies' salivary proteins have been related to endemic PF etiopathogenesis. Firstly reported in Brazilian endemic PF foci in NSPS, and later also described in Tunisia, ${ }^{11}$ the hypothesis that exposure to flies' bites may induce an autoimmunity trigger to $\lg$ g pathogenic autoantibodies against Dsg1 in genetically susceptible individuals is gained value in the last years. Self-antigen reaction could be explains by salivary peptides introduced into the host's skin while acquiring a blood meal triggering an antigen cross-reaction with Dsg1. Thus, some sandflies proteins have been proposed as the trigger: Maxadilan, LJM11 and recently LJM17, all three described in Lu. longipalpis sialome. Nevertheless, this hypothesis do not explain PF endemicity in the Old World and even in Brazilian regions where Lu. longipalpis is not widely distributed.

The similarity of some N. neivai salivary proteins to Maxadilan, represented by JAV08642.1, and/or to LJM11, represented by JAV07960.1, may reinforce this hypothesis; however, sera from individuals exposed to $N$. intermedia bites did not recognize the yellow proteins from Lu. Iongipalpis, and this lack of recognition maybe due to some of the differences observed in the amino acid sequence of these two proteins. ${ }^{21}$ Thus, it would be expected that N. neivai's salivary proteins might also have this lack of recognition.

Not a single salivary protein of $N$. neivai, neither Maxadilan nor LJM11 from Lu. longipalpis have a linear sequence match by BLAST with Dsg1 peptide (AAC83817.1). Interestedly, an anticoagulant protein of Lu. longipalpis saliva (AAD33512.1) has a $73 \%$ identity and $72 \%$ similarity on 11 amino acids (e6.3) when compared Dsg1 peptide from Homo sapiens. Further studies are required to assess the characteristic of this match.

Regarding that $\lg G$ antibodies against the salivary proteins extract from N. neivai positive correlated with IgG anti-Dsg1 in PF patients, ${ }^{8}$ we may expect than not a single peptide is acting as an independent antigen, and probably more than one protein is involved together in PF etiopathogenesis as reported Zaraa et al. in Tunisia, where endemic PF patients recognizes 12, 15, 30, 21 and $36 \mathrm{kDa}$ 
proteins from the SGH of $P$. papatasi. ${ }^{71}$ Pharmacological properties and conformational mimotopes of these proteins are necessary to better understand.

\section{CONCLUSION}

Leishmaniasis is still a frequent and neglected disease in Brazil. Our results increase valuable data related to New World Phlebotominae salivary proteins, complementing the findings reported in Lu. longipalpis and N. intermedia sialomes. The complete knowledge of these three main species of sandflies widely distributed in Brazil will brings new insights into the host-vector-parasite relationship of $L$. (L.) infantum and $L$. (V.) braziliensis infections and exposed interested targets looking for a vector-based vaccine.

Despite not matches between $N$. neivai and Dsg1 were found, the salivary proteins sequences deposited in the GenBank, will serve as reference to a possible antigenic peptide candidate to be the trigger of anti-Dsg1 autoantibodies production in Brazilian endemic pemphigus. 


\section{TABLES}

Table 1. Classification of transcripts originating from the sialotranscriptome of Nyssomyia neivai

\begin{tabular}{|l|c|c|c|c|}
\hline \multicolumn{1}{|c|}{ Class } & \# of contigs & \% of contigs & RPKM & \% RPKM \\
\hline Secreted & 494 & 41.2 & $1,203,951$ & 92.4 \\
\hline Housekeeping & 399 & 33.3 & 42,119 & 3.2 \\
\hline Unknown & 295 & 24.6 & 56,243 & 4.3 \\
\hline Viral products & 3 & 0.3 & 31 & 0.0 \\
\hline Transposable elements & 9 & 0.8 & 52 & 0.0 \\
\hline Total & 1,200 & 100 & $1,302,396$ & 100 \\
\hline
\end{tabular}


Table 2. Classification of secreted proteins originating from the sialotranscriptome of Nyssomyia neivai

\begin{tabular}{|c|c|c|c|c|c|}
\hline \multicolumn{2}{|c|}{ Putative Secreted proteins } & $\begin{array}{c}\text { \# of } \\
\text { contigs }\end{array}$ & $\begin{array}{c}\% \text { of } \\
\text { contigs }\end{array}$ & RPKM & $\begin{array}{c}\% \\
\text { RPKM }\end{array}$ \\
\hline \multirow{8}{*}{ Enzymes } & Proteases & 53 & 10.7 & 1186 & 0.1 \\
\hline & Endonuclease & 4 & 0.8 & 4927 & 0.4 \\
\hline & Hyaluronidase & 7 & 1.4 & 6887 & 0.6 \\
\hline & Lipases* & 8 & 1.6 & 53 & 0.0 \\
\hline & Alpha amylase* & 1 & 0.2 & 2 & 0.0 \\
\hline & Apyrase & 3 & 0.6 & 18214 & 1.5 \\
\hline & 5'nucleotidase & 4 & 0.8 & 7537 & 0.6 \\
\hline & Adenosine deaminase & 2 & 0.4 & 2923 & 0.2 \\
\hline \multirow{3}{*}{$\begin{array}{l}\text { Other ubiquitous } \\
\text { protein families }\end{array}$} & Protease inhibitors & $\overline{77}$ & $\overline{1.4}$ & 48 & 0.0 \\
\hline & Antigen 5 protein & 6 & 1.2 & 47405 & 3.9 \\
\hline & Antimicrobial peptides & 8 & 1.6 & 781 & 0.1 \\
\hline \multirow{9}{*}{$\begin{array}{l}\text { Small molecule } \\
\text { binding proteins }\end{array}$} & $\mathrm{JH} / \mathrm{PB} / \mathrm{OBP}$ & 36 & 7.3 & 1393 & 0.1 \\
\hline & Hormones & 3 & 0.6 & 29 & 0.0 \\
\hline & C type lectins & 20 & 4.0 & 190860 & 15.9 \\
\hline & Galectin & 1 & 0.2 & 3 & 0.0 \\
\hline & ML domain salivary protein & 13 & 2.6 & 69404 & 5.8 \\
\hline & Lipocalins & 3 & 0.6 & 147 & 0.0 \\
\hline & Yellow protein family & 13 & 2.6 & 61755 & 5.1 \\
\hline & Mucins & 22 & 4.5 & 13174 & 1.1 \\
\hline & $\begin{array}{l}\text { Diptera conserved salivary secreted } \\
\text { peptide }\end{array}$ & 59 & 11.9 & 3523 & 0.3 \\
\hline $\begin{array}{c}\text { Hematophagous } \\
\text { Nematocera } \\
\text { specific families }\end{array}$ & D7 family & 4 & 0.8 & 26832 & 2.2 \\
\hline \multirow{14}{*}{$\begin{array}{l}\text { Sand fly specific } \\
\text { families }\end{array}$} & Maxadilan & 16 & 3.2 & 187866 & 15.6 \\
\hline & $56.6 \mathrm{kDa}$ salivary protein & 3 & 0.6 & 1029 & 0.1 \\
\hline & Gly rich salivary protein & 6 & 1.2 & 808 & 0.1 \\
\hline & Toxin-like peptide & 12 & 2.4 & 24330 & 2.0 \\
\hline & SP13-15 protein family & 18 & 3.6 & 414587 & 34.4 \\
\hline & $10 \mathrm{kDa}$ family & 3 & 0.6 & 40594 & 3.4 \\
\hline & $14.21 \mathrm{kDa}$ family & 2 & 0.4 & 8955 & 0.7 \\
\hline & $15.5 \mathrm{kDa}$ family & 1 & 0.2 & 13 & 0.0 \\
\hline & $30 \mathrm{kDa}$ family & 2 & 0.4 & 16470 & 1.4 \\
\hline & 32.4 salivary protein - Lufaxin & 2 & 0.4 & 7913 & 0.7 \\
\hline & $34 \mathrm{kDa}$ family & 1 & 0.2 & 6850 & 0.6 \\
\hline & $38.8 \mathrm{kDa}$ family & 1 & 0.2 & 1958 & 0.2 \\
\hline & Nyssomyia specific & 1 & 0.2 & 3602 & 0.3 \\
\hline & Hypothetical secreted protein & 149 & 30.2 & 31893 & 2.6 \\
\hline \multicolumn{2}{|r|}{ TOTAL } & 494 & 100.0 & 1203951 & \\
\hline
\end{tabular}




\section{References}

1. Burza S, Croft SL, Boelaert M. Leishmaniasis. Lancet. 2018;392(10151):951-970.

2. Serafim TD, Coutinho-Abreu IV, Oliveira F, Meneses C, Kamhawi S, Valenzuela JG. Sequential blood meals promote Leishmania replication and reverse metacyclogenesis augmenting vector infectivity. Nat Microbiol. 2018;3(5):548-555.

3. Abdeladhim M, Kamhawi S, Valenzuela JG. What's behind a sand fly bite? The profound effect of sand fly saliva on host hemostasis, inflammation and immunity. Infect Genet Evol. 2014;28:691-703.

4. Luz NF, DeSouza-Vieira T, De Castro W, et al. Saliva Induces Heme Oxygenase-1 Expression at Bite Sites. Front Immunol. 2018;9:2779.

5. Anversa L, Tiburcio MGS, Richini-Pereira VB, Ramirez LE. Human leishmaniasis in Brazil: A general review. Rev Assoc Med Bras (1992). 2018;64(3):281-289.

6. Andrade Filho JD, Galati EA, Falcão AL. Nyssomyia intermedia (Lutz \& Neiva, 1912) and Nyssomyia neivai (Pinto, 1926) (Diptera: Psychodidae: Phlebotominae) geographical distribution and epidemiological importance. Mem Inst Oswaldo Cruz. 2007;102(4):481-487.

7. Brochado MJ, Nascimento DF, Campos W, Deghaide NH, Donadi EA, Roselino AM. Differential HLA class I and class II associations in pemphigus foliaceus and pemphigus vulgaris patients from a prevalent Southeastern Brazilian region. J Autoimmun. 2016.

8. Vernal S, Pepinelli M, Casanova C, et al. Insights into the epidemiological link between biting flies and pemphigus foliaceus in southeastern Brazil. Acta Trop. 2017;176:455-462.

9. Roselino AM, Figueiredo JFC, Kounga K, Reddy V, Lerner EA. Serum IgG from pemphigus foliaceus patients reacts against maxadilan. J Investig Dermatol. 2001;117:460.

10. Qian Y, Culton DA, Jeong JS, Trupiano N, Valenzuela JG, Diaz LA. Non-infectious environmental antigens as a trigger for the initiation of an autoimmune skin disease. Autoimmun Rev. 2016.

11. Casanova C, Colla-Jacques FE, Hamilton JG, Brazil RP, Shaw JJ. Distribution of Lutzomyia longipalpis chemotype populations in Sao Paulo state, Brazil. PLoS Negl Trop Dis. 2015;9(3):e0003620.

12. Abdeladhim M, Jochim RC, Ben Ahmed M, et al. Updating the salivary gland transcriptome of Phlebotomus papatasi (Tunisian strain): the search for sand fly-secreted immunogenic proteins for humans. PLoS One. 2012;7(11):e47347.

13. Rohoušová I, Subrahmanyam S, Volfová V, et al. Salivary gland transcriptomes and proteomes of Phlebotomus tobbi and Phlebotomus sergenti, vectors of leishmaniasis. PLoS Negl Trop Dis. 2012;6(5):e1660.

14. Hostomska J, Volfova V, Mu J, et al. Analysis of salivary transcripts and antigens of the sand fly Phlebotomus arabicus. BMC genomics. 2009;10:282.

15. Anderson JM, Oliveira F, Kamhawi S, et al. Comparative salivary gland transcriptomics of sandfly vectors of visceral leishmaniasis. BMC Genomics. 2006;7:52.

16. Oliveira F, Kamhawi S, Seitz AE, et al. From transcriptome to immunome: Identification of DTH inducing proteins from a Phlebotomus ariasi salivary gland cDNA library. Vaccine. 2006;24(3):374-390.

17. Martín-Martín I, Molina R, Jiménez M. Identifying salivary antigens of Phlebotomus argentipes by a 2DE approach. Acta Trop. 2013;126(3):229-239.

18. VIkova M, Sima M, Rohousova I, et al. Comparative analysis of salivary gland transcriptomes of Phlebotomus orientalis sand flies from endemic and non-endemic foci of visceral leishmaniasis. PLoS Negl Trop Dis. 2014;8(2):e2709. 
19. Kato $\mathrm{H}$, Anderson JM, Kamhawi $\mathrm{S}$, et al. High degree of conservancy among secreted salivary gland proteins from two geographically distant Phlebotomus duboscqi sandflies populations (Mali and Kenya). BMC Genomics. 2006;7:226.

20. Kato H, Jochim RC, Gomez EA, et al. Analysis of salivary gland transcripts of the sand fly Lutzomyia ayacuchensis, a vector of Andean-type cutaneous leishmaniasis. Infect Genet Evol. 2013;13:56-66.

21. de Moura TR, Oliveira F, Carneiro MW, et al. Functional transcriptomics of wild-caught Lutzomyia intermedia salivary glands: identification of a protective salivary protein against Leishmania braziliensis infection. PLoS Negl Trop Dis. 2013;7(5):e2242.

22. Valenzuela JG, Garfield M, Rowton ED, Pham VM. Identification of the most abundant secreted proteins from the salivary glands of the sand fly Lutzomyia longipalpis, vector of Leishmania chagasi. J Exp Biol. 2004;207(Pt 21):3717-3729.

23. Abdeladhim M, V Coutinho-Abreu I, Townsend S, et al. Molecular Diversity between Salivary Proteins from New World and Old World Sand Flies with Emphasis on Bichromomyia olmeca, the Sand Fly Vector of Leishmania mexicana in Mesoamerica. PLoS Negl Trop Dis. 2016;10(7):e0004771.

24. Ribeiro JM, Valenzuela JG, Pham VM, et al. An insight into the sialotranscriptome of Simulium nigrimanum, a black fly associated with fogo selvagem in South America. Am J Trop Med Hyg. 2010;82(6):1060-1075.

25. Lombardi $\mathrm{C}$, Borges $\mathrm{PC}$, Chaul $\mathrm{A}$, et al. Environmental risk factors in endemic pemphigus foliaceus (Fogo selvagem). "The Cooperative Group on Fogo Selvagem Research". J Invest Dermatol. 1992;98(6):847-850.

26. Eaton DP, Diaz LA, Hans-Filho G, et al. Comparison of black fly species (Diptera: Simuliidae) on an Amerindian reservation with a high prevalence of fogo selvagem to neighboring disease-free sites in the State of Mato Grosso do Sul, Brazil. The Cooperative Group on Fogo Selvagem Research. J Med Entomol. 1998;35(2):120-131.

27. Souza AP, Andrade BB, Aquino D, et al. Using recombinant proteins from Lutzomyia longipalpis saliva to estimate human vector exposure in visceral Leishmaniasis endemic areas. PLoS Negl Trop Dis. 2010;4(3):e649.

28. Araujo RN, Silva NCS, Mendes-Sousa A, et al. RNA-seq analysis of the salivary glands and midgut of the Argasid tick Ornithodoros rostratus. Scientific reports. 2019;9(1):6764.

29. Birol I, Jackman SD, Nielsen CB, et al. De novo transcriptome assembly with ABySS. Bioinformatics. 2009;25(21):2872-2877.

30. Luo R, Liu B, Xie Y, et al. Erratum: SOAPdenovo2: an empirically improved memory-efficient short-read de novo assembler. Gigascience. 2015;4:30.

31. Karim S, Singh P, Ribeiro JM. A deep insight into the sialotranscriptome of the gulf coast tick, Amblyomma maculatum. PLoS One. 2011;6(12):e28525.

32. Mortazavi A, Williams BA, McCue K, Schaeffer L, Wold B. Mapping and quantifying mammalian transcriptomes by RNA-Seq. Nature methods. 2008;5(7):621-628.

33. Valenzuela JG, Belkaid Y, Garfield MK, et al. Toward a defined anti-Leishmania vaccine targeting vector antigens: characterization of a protective salivary protein. $J$ Exp Med. 2001;194(3):331-342.

34. Coutinho-Abreu IV, Valenzuela JG. Comparative Evolution of Sand Fly Salivary Protein Families and Implications for Biomarkers of Vector Exposure and Salivary Vaccine Candidates. Front Cell Infect Microbiol. 2018;8:290. 
35. Alvarenga $\mathrm{PH}, \mathrm{Xu} \mathrm{X}$, Oliveira $\mathrm{F}$, et al. Novel family of insect salivary inhibitors blocks contact pathway activation by binding to polyphosphate, heparin, and dextran sulfate. Arterioscler Thromb Vasc Biol. 2013;33(12):2759-2770.

36. Gholami E, Oliveira F, Taheri T, et al. DNA plasmid coding for Phlebotomus sergenti salivary protein PsSP9, a member of the SP15 family of proteins, protects against Leishmania tropica. PLoS Negl Trop Dis. 2019;13(1):e0007067.

37. Weis WI, Taylor ME, Drickamer K. The C-type lectin superfamily in the immune system. Immunol Rev. 1998;163:19-34.

38. Charlab R, Valenzuela JG, Rowton ED, Ribeiro JM. Toward an understanding of the biochemical and pharmacological complexity of the saliva of a hematophagous sand fly Lutzomyia longipalpis. Proc Natl Acad Sci U S A. 1999;96(26):15155-15160.

39. Collin N, Assumpcao TC, Mizurini DM, et al. Lufaxin, a novel factor Xa inhibitor from the salivary gland of the sand fly Lutzomyia longipalpis blocks protease-activated receptor 2 activation and inhibits inflammation and thrombosis in vivo. Arterioscler Thromb Vasc Biol. 2012;32(9):2185-2198.

40. Lerner EA, Ribeiro JM, Nelson RJ, Lerner MR. Isolation of maxadilan, a potent vasodilatory peptide from the salivary glands of the sand fly Lutzomyia longipalpis. J Biol Chem. 1991;266(17):11234-11236.

41. Morris RV, Shoemaker CB, David JR, Lanzaro GC, Titus RG. Sandfly maxadilan exacerbates infection with Leishmania major and vaccinating against it protects against $\mathrm{L}$. major infection. J Immunol. 2001;167(9):5226-5230.

42. Brodie TM, Smith MC, Morris RV, Titus RG. Immunomodulatory effects of the Lutzomyia longipalpis salivary gland protein maxadilan on mouse macrophages. Infect Immun. 2007;75(5):2359-2365.

43. Titus RG, Bishop JV, Mejia JS. The immunomodulatory factors of arthropod saliva and the potential for these factors to serve as vaccine targets to prevent pathogen transmission. Parasite Immunol. 2006;28(4):131-141.

44. Milleron RS, Ribeiro JM, Elnaime D, Soong L, Lanzaro GC. Negative effect of antibodies against maxadilan on the fitness of the sand fly vector of American visceral leishmaniasis. Am J Trop Med Hyg. 2004;70(3):278-285.

45. Lanzaro GC, Lopes AH, Ribeiro JM, et al. Variation in the salivary peptide, maxadilan, from species in the Lutzomyia longipalpis complex. Insect Mol Biol. 1999;8(2):267-275.

46. Warburg A, Saraiva E, Lanzaro GC, Titus RG, Neva F. Saliva of Lutzomyia longipalpis sibling species differs in its composition and capacity to enhance leishmaniasis. Philos Trans $R$ Soc Lond B Biol Sci. 1994;345(1312):223-230.

47. Ribeiro JM, Katz O, Pannell LK, Waitumbi J, Warburg A. Salivary glands of the sand fly Phlebotomus papatasi contain pharmacologically active amounts of adenosine and 5'-AMP. $J$ Exp Biol. 1999;202(Pt 11):1551-1559.

48. Katz $\mathrm{O}$, Waitumbi JN, Zer R, Warburg A. Adenosine, AMP, and protein phosphatase activity in sandfly saliva. Am J Trop Med Hyg. 2000;62(1):145-150.

49. Aires J, Casanova C, Vernal S, et al. Maxadilan-simile expression in Nyssomyia neivai, a sandfly vector in an endemic region of Brazil, and its immunogenicity in patients with American tegumentary leishmaniasis. Mem Inst Oswaldo Cruz. 2017;112(2):116-122.

50. Casanova C, Colla-Jacques FE, Hamilton JG, Brazil RP, Shaw JJ. Distribution of Lutzomyia longipalpis chemotype populations in São Paulo state, Brazil. PLoS Negl Trop Dis. 2015;9(3):e0003620. 
51. Stahelin RV. Lipid binding domains: more than simple lipid effectors. J Lipid Res. 2009;50 Suppl:S299-304.

52. Francischetti IM, Sa-Nunes A, Mans BJ, Santos IM, Ribeiro JM. The role of saliva in tick feeding. Front Biosci (Landmark Ed). 2009;14:2051-2088.

53. Schmitzová J, Klaudiny J, Albert $\mathrm{S}$, et al. A family of major royal jelly proteins of the honeybee Apis mellifera L. Cell Mol Life Sci. 1998;54(9):1020-1030.

54. Albert S, Bhattacharya D, Klaudiny J, Schmitzová J, Simúth J. The family of major royal jelly proteins and its evolution. J Mol Evol. 1999;49(2):290-297.

55. Alves-Silva J, Ribeiro JM, Van Den Abbeele J, et al. An insight into the sialome of Glossina morsitans morsitans. BMC Genomics. 2010;11:213.

56. Andersen JF, Pham VM, Meng Z, Champagne DE, Ribeiro JM. Insight into the sialome of the Black Fly, Simulium vittatum. J Proteome Res. 2009;8(3):1474-1488.

57. Teixeira C, Gomes R, Collin N, et al. Discovery of markers of exposure specific to bites of Lutzomyia longipalpis, the vector of Leishmania infantum chagasi in Latin America. PLoS Negl Trop Dis. 2010;4(3):e638.

58. Xu X, Oliveira F, Chang BW, et al. Structure and function of a "yellow" protein from saliva of the sand fly Lutzomyia longipalpis that confers protective immunity against Leishmania major infection. J Biol Chem. 2011;286(37):32383-32393.

59. Collin N, Gomes R, Teixeira C, et al. Sand fly salivary proteins induce strong cellular immunity in a natural reservoir of visceral leishmaniasis with adverse consequences for Leishmania. PLoS Pathog. 2009;5(5):e1000441.

60. Abbehusen MMC, Cunha J, Suarez MS, et al. Immunization of Experimental Dogs With Salivary Proteins From. Front Immunol. 2018;9:2558.

61. Gomes R, Teixeira C, Teixeira MJ, et al. Immunity to a salivary protein of a sand fly vector protects against the fatal outcome of visceral leishmaniasis in a hamster model. Proc Natl Acad Sci U S A. 2008;105(22):7845-7850.

62. Cunha JM, Abbehusen M, Suarez M, Valenzuela J, Teixeira CR, Brodskyn Cl. Immunization with LJM11 salivary protein protects against infection with Leishmania braziliensis in the presence of Lutzomyia longipalpis saliva. Acta Trop. 2018;177:164-170.

63. Oliveira F, Lawyer PG, Kamhawi S, Valenzuela JG. Immunity to distinct sand fly salivary proteins primes the anti-Leishmania immune response towards protection or exacerbation of disease. PLoS Negl Trop Dis. 2008;2(4):e226.

64. Tlili A, Marzouki S, Chabaane E, et al. Phlebotomus papatasi Yellow-Related and Apyrase Salivary Proteins Are Candidates for Vaccination against Human Cutaneous Leishmaniasis. $J$ Invest Dermatol. 2018;138(3):598-606.

65. Ribeiro JM, Francischetti IM. Role of arthropod saliva in blood feeding: sialome and postsialome perspectives. Annu Rev Entomol. 2003;48:73-88.

66. Champagne DE, Smartt CT, Ribeiro JM, James AA. The salivary gland-specific apyrase of the mosquito Aedes aegypti is a member of the 5'-nucleotidase family. Proc Natl Acad Sci $U$ S A. 1995;92(3):694-698.

67. Ribeiro JM, Mans BJ, Arca B. An insight into the sialome of blood-feeding Nematocera. Insect Biochem Mol Biol. 2010;40(11):767-784.

68. Mans BJ. Evolution of vertebrate hemostatic and inflammatory control mechanisms in bloodfeeding arthropods. J Innate Immun. 2011;3(1):41-51.

69. Jablonka W, Kim IH, Alvarenga PH, Valenzuela JG, Ribeiro JMC, Andersen JF. Functional and structural similarities of D7 proteins in the independently-evolved salivary secretions of sand flies and mosquitoes. Scientific reports. 2019;9(1):5340. 
70. Chagas $\mathrm{AC}, \mathrm{McPhie} \mathrm{P}$, San $\mathrm{H}$, et al. Simplagrin, a platelet aggregation inhibitor from Simulium nigrimanum salivary glands specifically binds to the Von Willebrand factor receptor in collagen and inhibits carotid thrombus formation in vivo. PLoS Negl Trop Dis. 2014;8(6):e2947.

71. Zaraa I, Boussoffara T, Ben Ahmed M, et al. Exposure to Phlebotomus papatasi and/or Leishmania major: possible etiologic link to Tunisian pemphigus. J Invest Dermatol. 2012;132(2):479-482. 


\section{Figures legends}

Figure 1. A - Tree of SP13-15 protein family of Nyssomyia neivai. B - Multiple alignments of SP1315 from Nyssomyia neivai with Nyssomyia intermedia and Lutzomyia longipalpis SP15 proteins

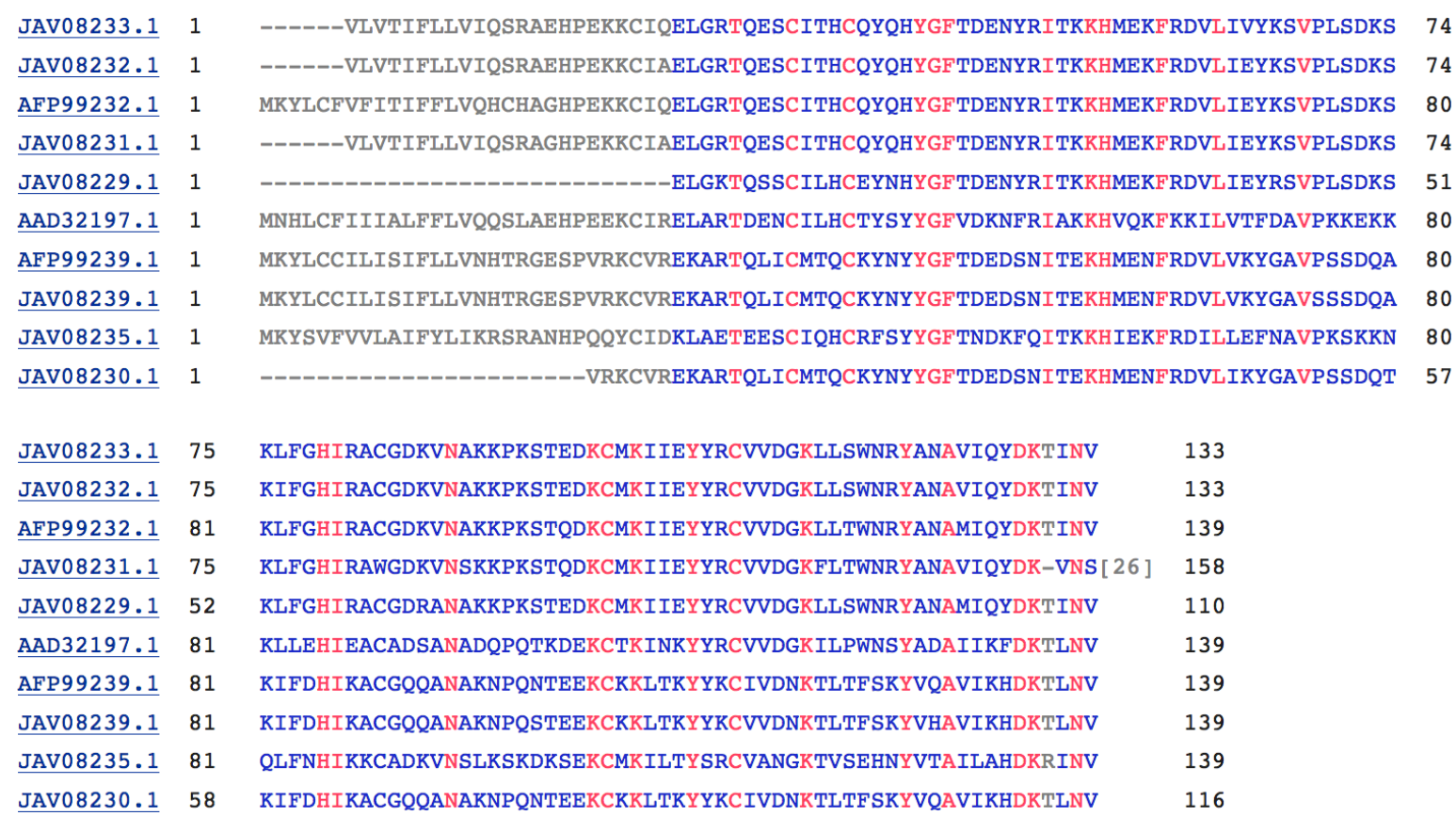


Figure 2. A - Tree of C-type lectin protein family of Nyssomyia neivai. B - Multiple alignments of Ctype lectin from Nyssomyia neivai with Nyssomyia intermedia and Lutzomyia longipalpis C-type lectin proteins

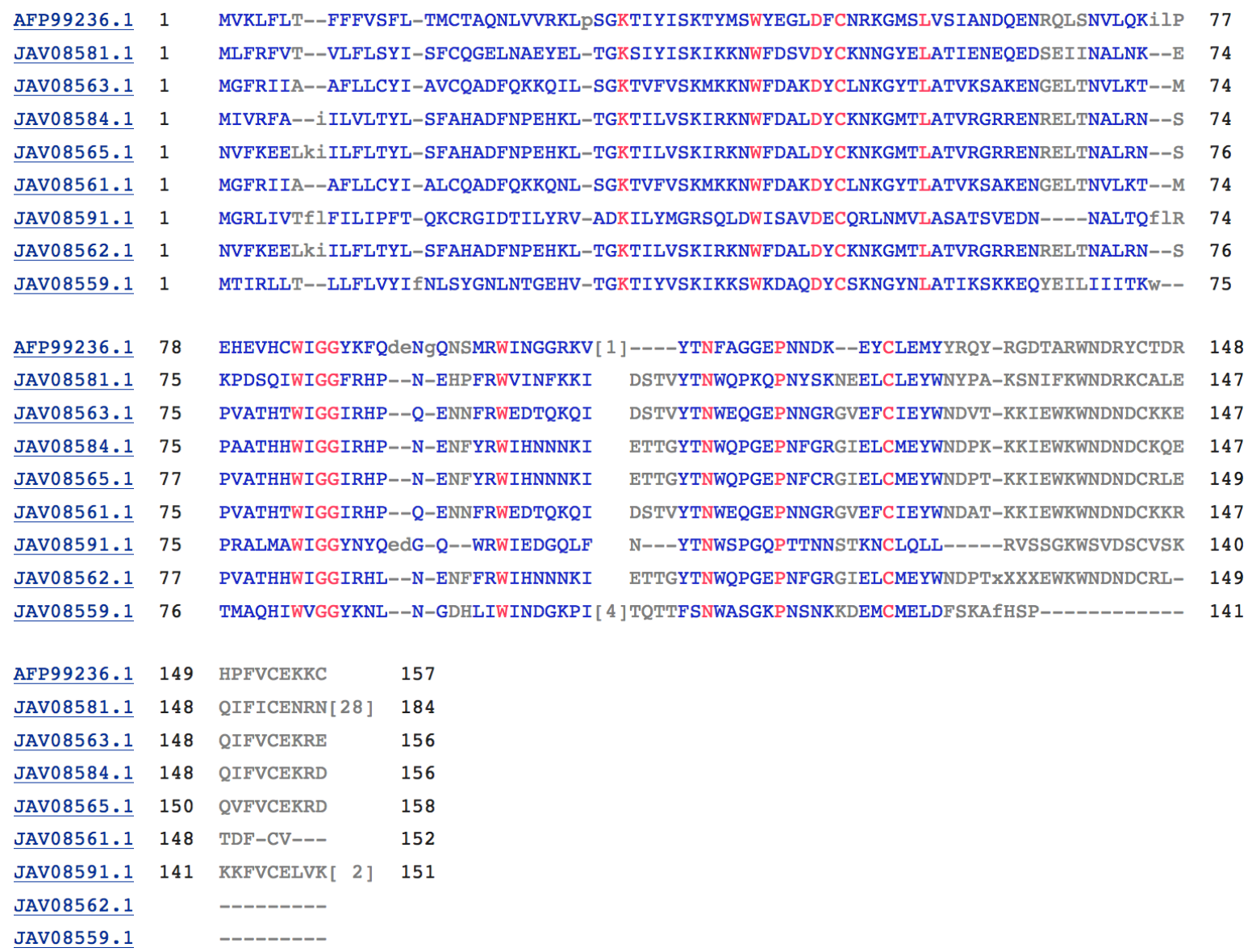


Figure 3. A - Tree of Maxadilan-simile protein family of Nyssomyia neivai. B - Multiple alignments of Maxadilan-simile from Nyssomyia neivai with Nyssomyia intermedia and Lutzomyia longipalpis Maxadilan-like proteins

\begin{tabular}{llllll}
$\underline{\text { AAA29288.1 }}$ & 1 & MKQILLISLVVVLAVFAFNVA[9]RKAIDDCQKQAHH & SNVLQTSVQTTATFTSMDTSQLPGNSVFKECMKQKKKE[5] & 86 \\
$\underline{\text { JAV08462.1 }}$ & 1 & MKNFILLLLAFALCIAYSNAA[7] ATILRECSQEANS & KNIHQIQVQTTATFTSMTTDQLPGH--FKKCVTERWKG[2] & 79 \\
\hline JAV08466.1 & 1 & MKKFVLVFLALAVLILCNEVE & AFSLPDCIKDENK & KMITQRQVHSTSTFSKLTEDDLAKK-VLANCLSKLASG & 71 \\
$\underline{\text { JAV08468.1 }}$ & 1 & MKKFVLVFLALAALILCNEIE & AFSLTDCIKEENK & KMIKKRQVHSTSTFSKLTEDELAKK-ALANCLNKLASG & 71 \\
$\underline{\text { JAV08471.1 }}$ & 1 & MKKFVLVFLALAVLILCNEIE & AFSLRDCINEENK & KMMEKRQVHSTSTFSKLTEDELSKK-ALAICLNRLGSG & 71 \\
$\underline{\text { AFP99237.1 }}$ & 1 & MKKFVLVFLALAVLILCNEVE & AFSLRDCVNDENK & KMIAQRQAHSTSTFSKLTEDELSKK-ALAICLNRLGSG & 71 \\
$\underline{\text { JAV08472.1 }}$ & 1 & MKKFVLVFLALAVLILCNEIE & AFSLRDCINEENK & KMMEKRQVHSTSTFSKLTEDDLSKQ-ALAICLNRLGSG & 71 \\
$\underline{\text { JAV08467.1 }}$ & 1 & MKKFVLVFLALAVLILCVEVE & AFSLRDCINDENK & KMMAQRQVHSTSTFSKLTEDDLSKQ-VLAICLSRLGSG & 71 \\
$\underline{\text { AFP99245.1 }}$ & 1 & MRIGLILLFAAVVLVFCDALP[5]TQIGQPCEHNIVK[7]KSKAKDAIAGLFTKAKSALKDVLKK-AKDKVKEKVAQH[5] & 88
\end{tabular}


Figure 4. A - Tree of ML-domain protein family of Nyssomyia neivai. B - Multiple alignments of MLdomain from Nyssomyia neivai with Nyssomyia intermedia and Lutzomyia longipalpis ML-domain proteins

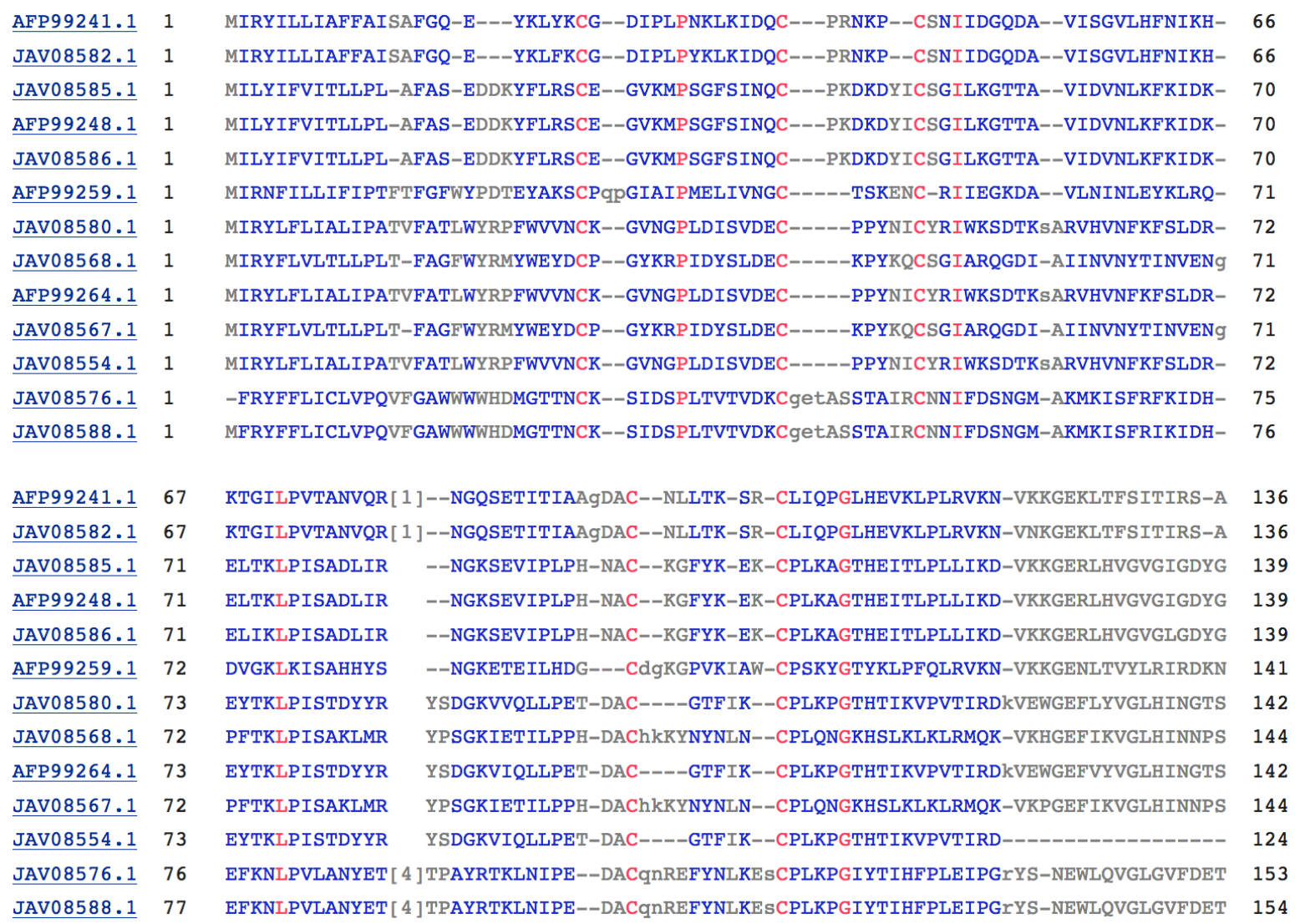


Figure 5. A - Tree of Yellow-related protein family of Nyssomyia neivai. B - Multiple alignments of Yellow-related protein from Nyssomyia neivai with Nyssomyia intermedia and Lutzomyia longipalpis Yellow-related protein

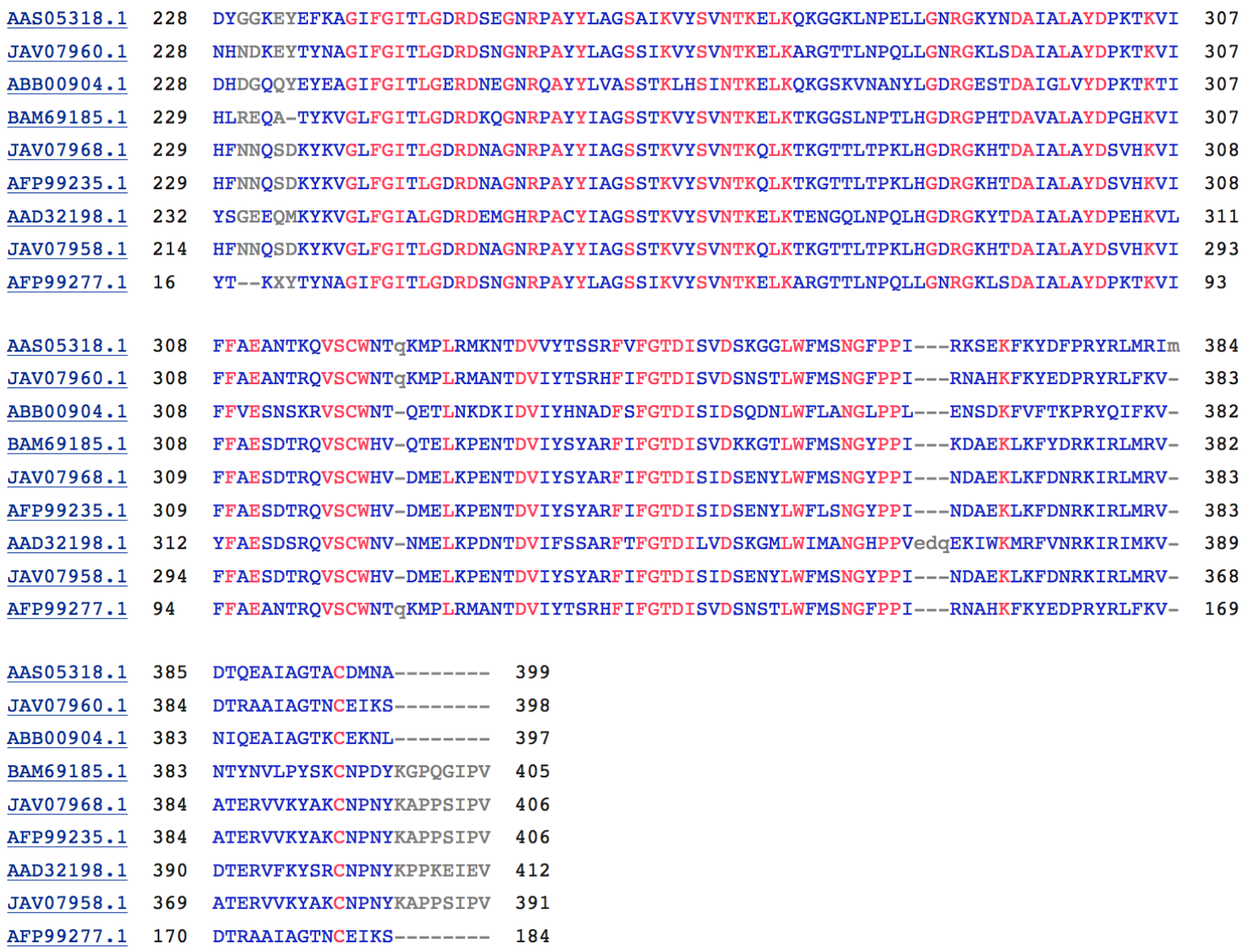


Conclusão 


\section{CONCLUSÃO}

Brasil representa um cenário perfeito para a tríade das doenças autoimunes: genética, inflamação e meio ambiente. O perfil genético ( $H L A$ de classe I e II) foi bem identificado na população do sudeste brasileiro, exibindo alelos de suscetibilidade específicos para o desenvolvimento do PF. Nesta mesma população, através dos resultados da presente tese, confirmamos a relação epidemiológica (fator de risco/doença $=$ inseto/PF) entre os aglomerados de PF e a distribuição geográfica das principais espécies de insetos antropofílicos. Da mesma forma, também confirmamos que os pacientes com PF do sudeste brasileiro foram expostos as picadas desses insetos, desenvolvendo anticorpos da classe IgG contra o extrato proteico salivar total, contra as proteínas salivares mais imunogênicas desses extratos e o reconhecimento de mais de uma fração proteica desses extratos salivares. Paralelamente também observamos a resposta de hipersensibilidade tipo 1 mediada por anticorpos da classe IgE contra os antígenos salivares supracitados. De maneira complementar, analisamos o sialoma de uma das principais espécies de flebotomíneos relacionadas com o PF. De maneira global, considerando o estado da arte e nossos resultados, finalizamos essa tese com uma nova proposta para explicar a endemicidade do PF incluindo a participação das picadas desses insetos hematófagos: S. nigrimanum e N. neivai.

\subsection{PROSPECTIVAS}

Nossa proposta abre portas para novas pesquisas, expandindo os horizontes no entendimento do PF endêmico, focando em uma concepção inédita e inovadora que servirá de inspiração para novos estudos com o fim de confirmar ou excluir nossa hipótese. 


\section{REFERÊNCIAS BIBLIOGRÁFICAS}

ABIDA, $O$. et al. 'The familial feature of Tunisian endemic pemphigus foliaceus'. $\mathrm{Br} \mathrm{J}$ Dermatol, v.161, p.951-3, 2009

ABREU-VELEZ, A. M. et al. 'A unique form of endemic pemphigus in northern Colombia'. J Am Acad Dermatol. v. 49, p. 599-608, 2003

ABREU-VELEZ, A. M et al. 'Endemic pemphigus foliaceus over a century: Part I', N Am J Med Sci, v.2, p. 51-9, 2010

ADLER, P.H. 'The Black Flies (Simuliidae) of North America' . Connel University Press, Ithaca, New York, USA, p.941, 2004

ADLER, P.H. 'World blackflies (Diptera: Simuliidae): a comprehensive revision of the taxonomic and geographical inventory', p.1-193, 2019. Disponível em http://www.clemson.edu/cafls/biomia/pdfs/blackflyinventory.pdf (data de acesso 03 de Março de 2019)

AIRES, J. et al. 'Maxadilan-simile 147xpression. in Nyssomyia neivai, a sandfly vector in an endemic region of Brazil, and its immunogenicity in patients with American tegumentary leishmaniasis' . Mem Inst Oswaldo Cruz, v.112, p.116-22, 2017

ALCAIDE-MARTIN, A. J. et al. 'Epidemiologic study of 20 cases of pemphigus at Hospital Clinico Universitario Virgen de la Victoria de Malaga, Spain', Actas Dermosifiliogr, v.101, p.524-33, 2010

ALDAMA, A. et al. 'Pemphigus foliaceus: statistical observations in Paraguay from 1990 to 1995'. Med Cutan Ibero Lat Am. v. 24, p.235-40, 1996

ALPSOY, E. A. et al. 'Geographic variations in epidemiology of two autoimmune bullous diseases: pemphigus and bullous pemphigoid', Arch Dermatol Res, v.307, p. 291-8. 2015

AMAGAI, M. 'Preface to Journal of Dermatology special issue: pemphigus updates from around the world', J Dermatol, v.42, p.2, 2015

ANDRADE-FILHO, J.D. et al. 'Nyssomyia intermedia and Nyssomyia neivai geographical distribution and epidemiological importance'. Mem Inst Oswaldo Cruz, v.102, p.481-7, 2007

ARANHA CAMPOS, J. 'Pênfigo foliáceo (Fogo Selvagem). Aspectos clínicos e epidemiológicos' . Comp Melhoramentos, São Paulo, 1942.

AOKI, V. et al. 'Update on fogo selvagem, an endemic form of pemphigus foliaceus', $J$ Dermatol, v.42, p.18-26, 2015 
ASSUMPÇÃO, T.C. et al. 'An insight into the sialotranscriptome of Triatoma matogrossensis, a Kissing bug associated with fogo selvagem in South America'. Am J Trop Med Hyg, v.86, p.1005-14, 2012

BASTUJI-GARIN, S. et al. 'Comparative epidemiology of pemphigus in Tunisia and France: unusual incidence of pemphigus foliaceus in young Tunisian women' . J Invest Dermatol, v. 104, p.302-5, 1995

BRAGA, I.A. et al. 'Aedes aegypti: inseticidas, mecanismos de ação e resistencia'. Epidemiol Serv Saúde, v.16, p.279-93, 2007

BROCHADO, M. J. et al. 'Differential HLA class I and class II associations in pemphigus foliaceus and pemphigus vulgaris patients from a prevalent Southeastern Brazilian region', J Autoimmun, v.72, p. 19-24, 2016

BRUNS, G.R. et al. 'Serum immunoglobulin E in pemphigus'. J Invest Dermatol, v.71, p.217-8, 1978

CAMARGO-NEVES, V.L.F. et al. 'Leishmaniose Visceral Americana no Estado de São Paulo'. Rev Soc Bras Med Trop, v.32, p.63-4, 1999

CAMARGO-NEVES, V.L.F. et al. 'Correlação da presence de espécies de flebotomíneos (Diptera, Pshycodidae) com registros de Leishmaniose tegumentr americana no Estado de São Paulo'. Rev Soc Bras Med Trop, v.35, p.299-306, 2002

CAMARGO-NEVES, V.L.F. et al. 'A Leishmaniose Visceral Americana no estado de São Paulo: Situação epidemiológica 2001 - 2002'. Rev Soc Bras Med Trop, v.6, p.S2, 2003

CELERE, B. S. et al. 'Spatial Distribution of Pemphigus Occurrence over Five Decades in Southeastern Brazil', Am J Trop Med Hyg, v.97, p. 1737-45, 2017

CHACÓN, G. R et al. 'Historical notes on endemic pemphigus in South America'. Int J Dermatol. v. 51, p. 477-81, 2012

CHAGAS, A.C. et al. 'Situation of endemic pemphigus foliaceus in Mato Grosso do Sul, Brazil, 1990-1999'. Rev Lat Am Enfermagem, v.13, p.274-6, 2005

CHIOSSI, M. P. et al. 'Endemic Pemhigus foliaceus ("Fogo selvagem"): a series from the Northeastern region of the State of Sao Paulo, Brazil, 1973-1998'. Rev Inst Med Trop São Paulo. v. 43, p.59-62, 2001

CIRILLO, N. '150 ${ }^{\text {th }}$ anniversary series: Desmosomes in physiology and disease'. Cell Commun Adhes, v.21, p.85-8, 2014.

COSCARON, S; COSCARON-ARIAS, C.L. 'Neotropical Simuliidae (Diptera: Simuliidae)'. In: Adis J, Arias JR, Rueda-Delgado G \& Wantzen KM (Eds.): Aquatic Biodiversity in Latin America (ABLA), v.3, p.685, 2007 
CRAMERI, R. et al. 'Humoral and cell-mediated autoimmunity in allergy to Aspergillus fumigatus'. J Exp Med, v.184, p.265-70, 1996

CULTON, D.A. et al. 'Advances in pemphigus and its endemic pemphigus foliaceus (Fogo Selvagem) phenotype: a paradigm of human autoimmunity'. J Autoimmun, v.31, p.311-24, 2008

DIAZ, L.A. et al. 'Endemic pemphigus foliaceus (fogo selvagem). I. Clinical features and immunopathology', J Am Acad Dermatol, v.20, p. 657-69, 1989

DIAZ, L.A. et al. 'Anti-desmoglein-1 antibodies in onchocerciasis, leishmaniasis and Chagas disease suggest a possible etiological link to Fogo selvagem'. J Invest Dermatol, v.123, p.104551,2004

DIAZ, L.A. et al. 'The IgM anti-desmoglein 1 response distinguishes Brazilian pemphigus foliaceus (fogo selvagem) from other forms of pemphigus'. J Invest Dermatol, v.128, p.667-75, 2008

EATON, D.P. et al. 'Comparison of black fly species (Diptera: Simuliidae) on an Amerindian reservation with a high prevalence of fogo selvagem to neighboring disease-free sites in the State of Mato Grosso do Sul, Brazil. The Cooperative Group on Fogo Selvagem Research' . J Med Entomol, v.35, p.120-31, 1998

ETTINGER, R. et al. 'Pathogenic mechanisms of IgE-mediated inflammation in selfdestructive autoimmune responses' . Autoimmunity, v.50, p.25-36, 2017

EVANGELISTA, F. et al. 'Pathogenic IgG4 autoantibodies from endemic pemphigus foliaceus recognize a desmoglein-1 conformational epitope'. J Autoimmune, v.89, p.171-185, 2018

FEMIANO, F. 'Pemphigus vulgaris: recent advances in our understanding of its pathogenesis', Minerva Stomatol, v.56, p.215-23, 2007

FERREIRA, I.T. et al. 'Participação da população no controle da dengue: um análise da sensibilidade dos planes de saúde dos municípios do Estado de São Paulo, Brasil'. Cad Saude Publica, v.25, p.2683-94, 2009

FRANCO BROCHADO, M. J. et al. 'Data on HLA class I/II profile in Brazilian pemphigus patients', Data Brief, v.8, p.364-74, 2016

FRIEDMAN, H. et al. 'Endemic pemphigus foliaceus (fogo selvagem) in native Americans from Brazil', J Am Acad Dermatol, v.32,p.949-56, 1995

GALATI, E.A.B. 'Classificação de Phlebotominae'. In: Flebotomíneos do Brasil, FIOCRUZ, Rio de Janeiro, p.23-51, 2003

GLASSER, C.M. et al. 'Infestação do Estado de São Paulo por Aedes aegypti e Aedes albopictus'. Rev Saude Publica, v.34, p.570-7, 2000 
GOMES, A.C. et al. 'Nota sobre encontro de Phlebotominae (Diptera, Psychodidae) no litoral sul do estado de São Paulo'. Rev Saude Publica, v.24, p.319-20, 1990

GONÇALVES, G. A. P. et al. 'Incidência do pênfigo vulgar ultrapassa a do pênfigo foliáceo em região endêmica para pênfigo foliáceo: análise de série histórica de 21 anos'. An Bras Dermatol. v. 86, p.1109-12, 2011

GONZÁLEZ, F. et al. 'Endemic pemphigus foliaceus in Venezuela: report of two children'. Ped Dermatol, v. 23, p.132-5, 2006

GRIMALDI, D.; ENGEL, M. 'Evolution of the insects'. New York: Cambridge University Press, 2005.

GUZMAN, M.G.; HARRIS, E. 'Dengue'. Lancet, v.385, p.453-65, 2015

HAMMERS, C. M; STANLEY, J.R. 'Mechanisms of Disease: Pemphigus and Bullous Pemphigoid', Annu Rev Pathol, v.11, p.175-97, 2016

HANS-FILHO, G. et al. 'An active focus of high prevalence of fogo selvagem on an Amerindian reservation in Brazil. Cooperative Group on Fogo Selvagem Research'. J Invest Dermatol, v. 107, p.68-75, 1996

HEUPEL, W.M. et al. 'Pemphigus vulgaris IgG directly inhibit desmoglein 3 mediated transinteraction'. J Immun, v.181, p.1825-34, 2008.

HONORIO, N.A.; LOURENÇO-DE-OLIVEIRA, R. 'Frequencia de larvas e pupas de Aedes aegypti e Aedes albopictus em armadilhas, Brasil'. Rev Saude Publica, v.35, p.385-91, 2001

JABLONKA, W. et al. 'Functional and structural similarities of D7 proteins in the independently-evolved salivary secretions of sand flies and mosquitoes'. Sci Rep, v.9, p.5340, 2019

JEANNIN, P. et al. 'IgE versus IgG4 production can be differentially regulated by IL-10'. J Immunol, v.160, p.3555-61, 1998

JOLY, P. et al. 'Pemphigus group (vulgaris, vegetans, foliaceus, herpetiformis, brasiliensis)', Clin Dermatol, v. 29, p. 432-6. 2011

KALLEL SELLAMI, M. et al. 'Anti-desmoglein-1 antibodies are prevalent in Tunisian patients with hydatidosis and leishmaniasis'. Br J Dermatol, v.156, p.591-3, 2007

KASPERKIEWICZ, M.et al. 'Pemphigus', Nat Rev Dis Primers, v.3, p. 17026, 2017

KELLY, A. et al. 'Genetics of antigen processing and presentation'. Immunogenetics, v.71, p.161-70, 2019 
KERO, J. et al. 'Could TH1 and TH2 diseases coexist? Evaluation of asthma incidence in children with coeliac disease, type 1 diabetes, or rheumatoid arthritis: a register study'. J Allergy Clin Immunol, v.108, p.781-3, 2001

KITAJIMA, Y. ' $150^{\text {th }}$ Anniversary Series: Desmosomes and Autoimmune Disease, Perspective of Dynamic Desmosome Remodeling and Its Impairments in Pemphigus', Cell Commun Adhes, v. 21, p. 269-80, 2014

KOTTKE, M.D. et al. 'The desmosome: cell science lessons from human diseases', J Cell Sci, v.119, p.797-806, 2006

KONECZNY, I. 'A New Classification System for IgG4 Autoantibodies'. Front Immunol, v.9, p.97, 2018

KRIDIN, K. et al. 'Pemphigus vulgaris and pemphigus foliaceus: Differences in epidemiology and mortality'. Acta Derm Venereol, v.97, p. 1095-9, 2017

LARCHE, M. 'Regulatory T cells in allergy and asthma'. Chest, v.132, p.1007-14, 2007

LA SERRA, L. et al. 'Trace element profile in pemphigus foliaceus and in pemphigus vulgaris patients from Southeastern Brazil', J Trace Elem Med Biol, v.51, p.31-5, 2019

LERNER, E.A. et al. 'Isolation of maxadilan, a potent vasodilatory peptide from the salivary glands of the sand fly Lutzomyia longipalpis', J Biol Chem, v.266, p.11234-6, 1991

LI, N. et al. 'The Role of Intramolecular Epitope Spreading in the Pathogenesis of

Endemic Pemphigus Foliaceus (Fogo Selvagem)'. J Exp Med, v. 197, p.150110, 2003

LOMBARDI, C. et al. 'Environmental risk factors in endemic pemphigus foliaceus (Fogo selvagem). "The Cooperative Group on Fogo Selvagem Research'. J Invest Dermatol, v.98, p.847-50, 1992

MACHADO, A.R.D.S.R. et al. 'Herpes simplex virus 1 and cytomegalovirus are associated with pemphigus vulgaris but not with pemphigus foliaceus disease', Exp Dermatol, v.26, p.9668,2017

MARCONDES, C.B. 'A redescription of Lutzomyia (Nyssomyia) intermedia and resurrection of L. neivai' . Mem Inst Oswaldo Cruz, v.91, p.457-62, 1996

MARTINELLI, A. et al. 'Family study of monozygotic twins affected by pemphigus vulgaris'. Hum Immunol, v.77, p.600-4, 2016

MARTINS, M. et al. 'Masonella ozzardi in Amazonas, Brazil: prevalence and distribution in the municipality of Coari, in the middle Solimões river'. Mem Inst Oswaldo Cruz, v.105, p.24653,2010

MATIAS, A.B; ROSELINO, A.M.F. 'Pemphigus and psychological stress: a review of the literature'. Nasza Dermatologia Online. v.4, s.3, p. 616-8, 2013 
MEDEIROS, A.R. et al. 'DNA sequencing confirms the involvement of Lieshmania (L.) amazonensis in American tegumentary Leishmaniase in the State of São Paulo, Brazil'. Clinics, v.63, p.451-6, 2008

MEYER, N; MISERY, L. 'Geoepidemiologic considerations of auto-immune pemphigus', Autoimmun Rev, v.9, p.A379-82, 2010

MITTERMANN, I. et al. 'Autoimmunity and atopic dermatitis'. Curr Opin Allergy Clin Immunol, v.4, p.367-71, 2004

MURO, Y. 'Autoantibodies in atopic dermatitis'. J Dermatol Sci, v.25, p.171-8, 2001

NAGEL, A. et al. 'Clinical activity of pemphigus vulgaris relates to IgE autoantibodies against desmoglein 3'. Clin Immunol, v.134, p.320-30, 2010

ORTEGA-LOAYZA, A. G. et al. 'Endemic pemphigus foliaceus in the Peruvian Amazon'. Clin Exp Dermatol. v. 38, p.594-600, 2013

PEPINELli, M. 'Simuliidae (Diptera, Nematocera) do Estado de São Paulo'. Tese de Doutorado, Universidade Federal de São Carlos 2008. Disponível em: https://repositorio.ufscar.br/bitstream/handle/ufscar/2027/DissMP.pdf?sequence=1\&isAllowed=y

(Data de acesso 3 de Março de 2019)

PINHEIRO, F.P. et al. FP. 'Haemorrhagic syndrome of Altamira' . Lancet, v.1, p.639-42, 1974

POLlMANN, R. et al. 'Pemphigus: a Comprehensive Review on Pathogenesis, Clinical Presentation and Novel Therapeutic Approaches', Clin Rev in Allergy Immunol, v.54, p.1-25, 2018

QIAN, Y. et al. 'Antigen selection of anti-DSG1 autoantibodies during and before the onset of endemic pemphigus foliaceus' . J Invest Dermatol, v.129, p.2823-34, 2009

QIAN, Y. et al. 'IgE, IgM, and IgG4 anti-desmoglein 1 autoantibody profile in endemic pemphigus foliaceus (fogo selvagem)'. J Invest Dermatol, v.131, p.985-7, 2011

QIAN, Y. et al. 'Cutting Edge: Brazilian Pemphigus Foliaceus Anti-Desmoglein 1 Autoantibodies Cross-React with Sand Fly Salivary LJM11 Antigen'. J Immunol. v. 189, p.1535-9, 2012

QIAN, Y. et al. 'IgE anti-LJM11 sand fly salivary antigen may herald the onset of fogo selvagem in endemic Brazilian regions'. J Invest Dermatol, v.135, p.913-5, 2015

QIAN, Y. et al. 'Non-infectious environmental antigens as a trigger for the initiation of an autoimmune skin disease' . Autoimmun Rev, v.15, p. 923-30, 2016

REIDPATH, D.D. et al. 'Social sciences research in neglected tropical diseases 2: a bibliographic analysis'. Health Res Policy Syst, v.9, p.1, 2011 
RIBEIRO, J.M. et al. 'An insight into the sialotranscriptome of Simulium nigrimanum, a Black fly associated with fogo selvagem in South Brazil'. Am J Trop Med Hyg, v.82, p.1060-75, 2010

ROCHA-ALVAREZ, R. et al. 'Endemic Pemphigus Vulgaris'. Arch Dermatol, v.143, p.89599,2007

ROSELINO, A.M. et al. 'Serum IgG from pemphigus reacts against maxadilan', J Invest Dermatol, v.117, p.460, 2001

ROTTEM, M. 'Allergy and systemic diseases: the case of chronic urticaria and thyroid disease'. Isr Med Assoc J, v.4, p.889-90, 2002

RUOCCO, E. et al. 'Pemphigus: etiology, pathogenesis, and inducing or triggering factors: facts and controversies', Clin Dermatol, v.31, p. 374-81, 2013

SALEH, M.A. 'Pemphigus in the Arab world', J Dermatol, v.42, p.27-30, 2015

SANIKLIDOU, A.H. et al. 'IgE autoantibodies and their association with the disease activity and phenotype in bullous pemphigoid: a systematic review'. Arch Dermatol Res, v.310, p.11-28, 2018

SARDANA, K. et al. 'Is there an emergent need to modify the desmoglein compensation theory in pemphigus on the basis of Dsg ELISA data and alternative pathogenic mechanisms?'. Br J Dermatol, v.168, p.669-74, 2013

SHARMA, $\mathrm{P}$ et al. 'Beyond steric hindrance: The role of adhesion signaling pathways in the pathogenesis of pemphigus'. J Dermatol Sci, v. 48, p.1-14, 2007

SHIMABUKURO, P.H.F.; GALATI, E.A.B. 'Cheklist dos Phlebotominae (Diptera, Psychodidae) do Estado de São Paulo, Brasil, com comentários de sua distribuição geográfica'. Biota Neotropica, v.11, p.1-20, 2010

SHIMABUKURO, P.H.F et al. 'Geographical distribution of American Cutaneous Leishmaniasis and its phlebotomine vector (Diptera, Psychodidae) in the state of São Paulo, Brazil'. Parasites \& Vectors, v.3, p.121, 2010

SHELLEY, A.J. et al. 'Vectors of Onchocerca volvulus at the river Toototobi, Brazil'. J Helminthology, v.53, p.41-3, 1976

SHELLEY, A.J. et al. 'Biosystematic studies on the Simuliidae (Diptera) of the Amazonia onchocerciasis focus'. Bull Br Mus Nat Hist, v.66, p.1-120, 1997

SHELLEY A.J.; COSCARON S. 'Simuliid Blackflies (Diptera: Simuliidae) and Ceratopogonid Midges (Diptera: Ceratopogonidae) as Vectors of Mansonella ozzardi (Nematoda: Onchocercidae) in Northern Argentina'. Mem Inst Oswaldo Cruz, v.96, p.451-8, 2001 
SIMPSON, C.R. et al. 'Coincidence of immune-mediated diseases driven by Th1 and Th2 subsets suggests a common aetiology. A population-based study using computerized general practice data'. Clin Exp Allergy, v.32, p.37-42, 2002

SINHA, A. A. 'The genetics of pemphigus', Dermatol Clin, v.29, p. 381-91, 2011

SOUSA, J.X. et al. 'Profile of Trypanosoma cruzi reactivity in a population at high risk for endemic pemphigus foliaceus (Fogo selvagem)' . Am J Trop Med Hyg, v.87, p.675-80, 2012

SPINDLER, V. et al. 'Desmosomal Cadherins and Signaling: Lessons from Autoimmune Disease'. Cell Commun Adhes, v.21, p.77-84, 2014

STRAIT, R.T. et al. 'IgG-blocking antibodies inhibit IgE-mediated anaphylaxis in vivo through both antigen interception and Fc gamma RIIb cross-linking'. J Clin Invest, v.116, p.833-41, 2006

SUCEN ${ }^{\text {a: }}$ Superintendência de Controle de Endemias, Secretaria da Saúde, Governo do Estado de São Paulo. 'Programas->Leishmaniose Tegumentar Americana->Vetores 2015' Disponível em: http://www.saude.sp.gov.br/sucen-superintendencia-de-controle-de-

endemias/programas/leishmaniose-tegumentar-americana/vetores (Data de acesso em 03 de Março de 2019)

SUCEN ${ }^{\text {b}}$ : Superintendência de Controle de Endemias, Secretaria da Saúde, Governo do Estado de São Paulo. 'Programas->Dengue->Situação Atual 2015'. Disponível em: http://www.saude.sp.gov.br/sucen-superintendencia-de-controle-de-

endemias/programas/dengue/situacao-atual (Data de acesso em 03 de Março de 2019)

TAVAKOLPOUR, S. 'Current and future treatment options for pemphigus: Is it time to move towards more effective treatments?', Int Immunopharmacol, v.53, p.133-42, 2017

TEIXEIRA, M.G. et al. 'Dengue: twenty-five years since reemerging in Brazil'. Cad Saude Publica, v.25, p.S7-18, 2009

TOLEZANO, J.E. 'Ecoepidemiological aspects of American cutaneous leishmaniasis in the state of São Paulo, Brazil'. Mem Inst Oswaldo Cruz, v.89, p.427-34, 1994

TRAMPERT, D.C. et al. 'On the role of IgG4 in inflammatory conditions: lessons for IgG4related disease'. Biochim Biophys Acta Mol Basis Dis, v.1864, p.1401-9, 2018

VALENTA, R. et al. 'Recombinant allergens for immunoblot diagnosis of tree-pollen allergy' . J Allergy Clin Immunol, v.88, p.889-94, 1991

VALENTA, R. et al. 'Immunological and structural similarities among allergens: prerequisite for a specific and component-based therapy of allergy'. Immunol Cel Biol, v.74, p.187-94, 1996

VALENTA, R. et al. 'Immunoglobulin $\mathbf{E}$ response to human proteins in atopic patients'. J Invest Dermatol, v.107, p.203-8, 1997 
VALENTA, R. et al. 'Autoallergy: a pathogenetic factor in atopic dermatitis?' J Allergy Clin Immunol, v.105, p.432-7, 2000

VALENZUELA, J.G. et al. 'Identification of the most abundant secreted proteins from the salivary glands of the sand fly Lutzomyia longipalpis, vector of Leishmania chagasi', J Exp Biol, v.207, p.3717-29, 2004

VIEIRA, J. P. 'Novas contribuições ao estudo do pênfigo foliáceo (fogo selvagem) no Estado de São Paulo'. São Paulo, Empresa Gráfica da Revista dos Tribunais, 1940.

WALSH, P. et al. 'Relationship between pemphigus and American tegumentary leishmaniasis: insights from serological and genetic profiles'. Trans R Soc Trop Med Hyg, v.111, p.345-53, 2017

WAMBIER, C. G. et al. 'Image Gallery: A case of pemphigus vulgaris following Simulium spp. (Diptera) bites', Br J Dermatol, v.176, p.100, 2017

WARREN, S.J. et al. 'The prevalence of antibodies against desmoglein 1 in endemic pemphigus foliaceus in Brazil. Cooperative Group on Fogo Selvagem Research'. N Eng J Med, v.343, p.2330,2000

WHO: World Health Organization. 'Dengue: guidelines for diagnosis, treatment, prevention and control'. WHO Library, New Edition, 2009. Disponível em: http://whqlibdoc.who.int/publications/2009/9789241547871_eng.pdf?ua=1 (Data de acesso 03 de Março de 2019)

YOKOUCHI, M. et al. 'Pathogenic epitopes of autoantibodies in pemphigus reside in the amino-terminal adhesive region of desmogleins which are unmasked by proteolytic processing of prosequence'. J Invest Dermatol, v.129, p.2156-66, 2009

ZARAA, I. et al. 'Exposure to Phlebotomus papatasi and/or Leishmania major: possible etiologic link to Tunisian pemphigus'. J Invest Dermatol, v.132, p.479-82, 2012 
ANEXO 1 - Protocolo de extração de glândulas salivares de Aedes aegypti do Instituto de Imunologia, Universidade de São Paulo. Gentilmente fornecido pelo Prof. Dr. Anderson Sá-Nunes.

\section{PROTOCOLO DE EXTRAÇÃO DE GLÂNDULAS SALIVARES}

Materiais utilizados

- Isopor com gelo.

- Placa de petri com papel filtro para colocar os mosquitos.

- Placa de petri para colocar álcool 70\%.

- Duas pinças entomológicas.

- Estilete.

- Lâmina de vidro $5 \times 5 \mathrm{~cm}$.

- Pipeta Pasteur.

- Eppendorf com $100 \mu \mathrm{L}$ de PBS, Tubo Falcon de $15 \mathrm{~mL}$ com PBS.

- $\operatorname{PBS} 1 \mathrm{X}$.

Preparo para extração da glândula salivar do mosquito Aedes aegypti

1. Colocar os mosquitos na geladeira, pois a baixa temperatura faz com que eles fiquem "adormecidos" e permite que os mesmos sejam manipulados para posterior extração da glândula salivar.

2. Enquanto isso, ligar o Estereomicroscópio conforme orientação do POP 00008 (Protocolo de uso da Lupa);

3. No isopor com gelo colocar uma placa de petri com um papel filtro dentro, um tubo Falcon contendo PBS 1X para coleta junto com uma pipeta Pauster de plástico e um eppendorf contendo $100 \mu \mathrm{L}$ de PBS;

4. $\mathrm{Na}$ bancada deixar duas pinças, o estilete, a placa de petri com álcool $70 \%$ (para submergir os mosquitos antes da coleta), uma folha de papel toalha umedecida com água destilada (para descartar os mosquitos após a coleta e realizar a contagem dos mesmos);

5. Retirar os mosquitos da geladeira e colocá-los na placa de petri dentro do isopor com gelo.

Procedimentos para extração

I. Posicionar uma lâmina no centro da lupa e pingar uma gota de PBS;

II. Com uma pinça, retirar um mosquito da placa de petri e passar no álcool $70 \%$; com a outra pinça retirar as patas;

III. Deitar o mosquito sobre a lâmina (dentro da gota de PBS), acertar o foco da imagem e retirar a cabeça do mosquito com uma pinça.

IV. Deixar essa pinça de lado e segurar o estilete num ângulo de mais ou menos $20^{\circ}$ em relação ao mosquito e pressioná-lo devagar sobre seu tórax.

V. Assim que localizar a glândula, distanciá-la do mosquito utilizando a ponta do estilete.

VI. Retirar o mosquito da lâmina e deixá-lo sobre o papel umedecido para posterior contagem.

VII. Com a ajuda do estilete, coletar a glândula que ficou na lâmina e colocá-la dentro do eppendorf contendo PBS.

VIII. Armazenar no freezer $-80^{\circ} \mathrm{C}$. 
ANEXO 2 - Protocolo de extração proteica de epiderme do Intstitute of Cutaneous Cell Biology, Kurume University. Gentilmente fornecido pelo Prof. Dr. Takashi Hashimoto.

\section{EPIDERMAL PROTEIN EXTRACTION}

Preparation of epidermal and dermal extract of EDTA separated normal human skin

\section{- EDTA separation}

* All experiments should be done on the plastic dish cooled on ice.

1. Human foreskins keep at $4^{\circ} \mathrm{C}$ until used (use in the same day). Prepuce skin ( 3 pieces $\sim 5 \times 5 \mathrm{~cm}$ ).

2. Remove dermis as much as possible.

3. Wash foreskin with cold PBS.

4. Add the strips in 500ml of PBS containing $2 \mathrm{mM}$ EDTA and $1 \mathrm{mM}$ PMSF $(500 \mathrm{mM}$ EDTA $=2 \mathrm{ml}$ $+100 \mathrm{mM}$ PMSF $=5 \mathrm{ml})$.

5. Keep at $4{ }^{\circ} \mathrm{C}$ for $24 \mathrm{~h}$.

6. Change into a new buffer (see step 4 ) and keep at $4^{\circ} \mathrm{C}$ for another $24 \mathrm{~h}$.

7. Remove epidermis and collect it.

- Preparation of epidermal extracts.

1. Extraction buffer:

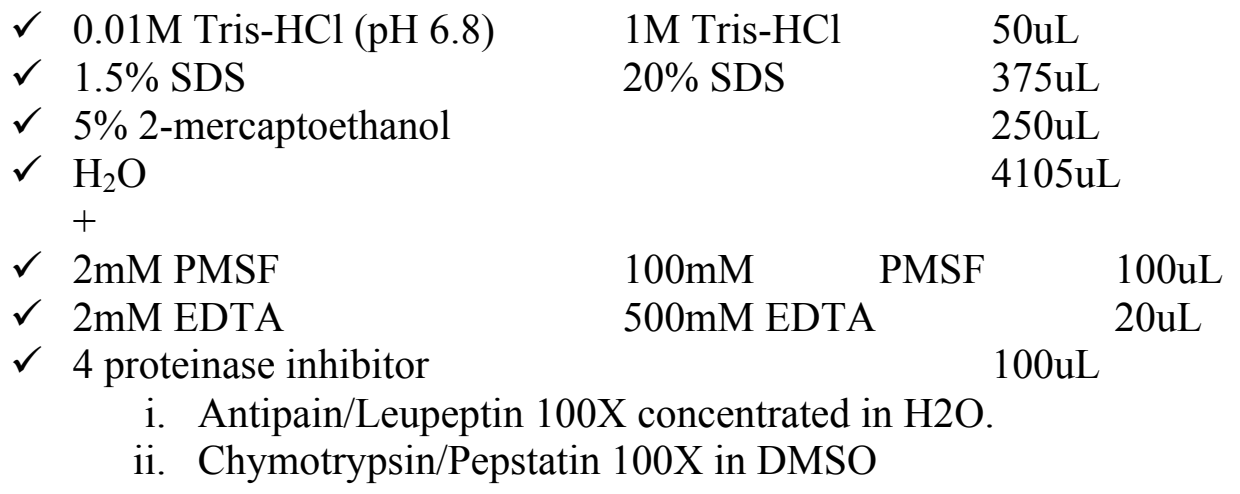

* Also can be used commercial proteinase inhibitor pool (100uL).

2. Add epidermis into extraction buffer (about $2 \mathrm{~mL}$ for 1 foreskin). Homogenize completely by homogenizer on ice for $30 \mathrm{~m}$.

3. Boll for $5 \mathrm{~min}$.

4. Centrifuged at $14,000 \mathrm{rpm}$ for $30 \mathrm{~m}$

Aliquots $(50 \mathrm{uL})$ and keep at $-80^{\circ} \mathrm{C}$. 
ANEXO 3 - Parecer do Comitê de Ética em Pesquisa da Faculdade de Medicina de Ribeirão Preto, Universidade de São Paulo

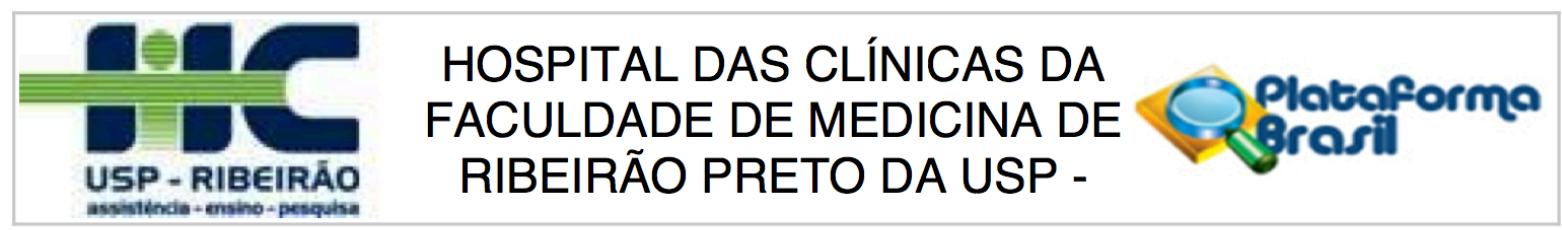

\section{PARECER CONSUBSTANCIADO DO CEP}

\section{DADOS DO PROJETO DE PESQUISA}

Título da Pesquisa: Mimetismo molecular de peptídeos salivares de insetos hematófagos com peptídeos epidérmicos na patogênese dos pênfigos

Pesquisador: Sebastian Vernal

Área Temática:

Versão: 2

CAAE: 35829314.0 .0000 .5440

Instituição Proponente: Hospital das Clínicas da Faculdade de Medicina de Ribeirão Preto da USP -

Patrocinador Principal: Financiamento Próprio

\section{DADOS DO PARECER}

Número do Parecer: 866.027

Data da Relatoria: 30/10/2014

\section{Apresentação do Projeto:}

Trata-se de projeto de pesquisa, nível Mestrado, a ser desenvolvido por Sebastian Vernal mestrando no programa da Clínica Médica da FMRP - USP, sobre orientação da Profa. Dra. Ana Maria Roselino. 